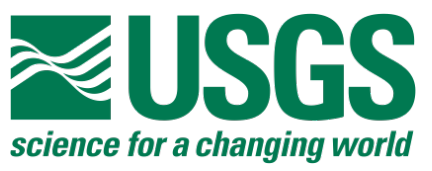

Supported by the USGS Earthquake Hazards Program

\title{
Evaluation of Hazardous Faults in the Intermountain West Region- Summary and Recommendations of a Workshop
}

By Anthony J. Crone, Kathleen M. Haller, and Joseph Z. Maharrey

Open-File Report 2009-1140

U.S. Department of the Interior U.S. Geological Survey 


\section{U.S. Department of the Interior \\ KEN SALAZAR, Secretary}

\section{U.S. Geological Survey \\ Suzette M. Kimbell, Acting Director}

U.S. Geological Survey, Reston, Virginia 2009

For product and ordering information:

World Wide Web: http://www.usgs.gov/pubprod

Telephone: 1-888-ASK-USGS

For more information on the USGS - the Federal source for science about the Earth, its natural and living resources, natural hazards, and the environment:

World Wide Web: http://www.usgs.gov

Telephone: 1-888-ASK-USGS

Suggested citation:

Crone, A.J., Haller, K.M., and Maharrey, J.Z., 2009, Evaluation of hazardous faults in the Intermountain West region-Summary and recommendations of a workshop: U.S. Geological Survey Open-File Report 2009-1140, 71 p.

Available at: http://pubs.usgs.gov/of/2009/1140/

Any use of trade, product, or firm names is for descriptive purposes only and does not imply endorsement by the U.S. Government.

Although this report is in the public domain, permission must be secured from the individual copyright owners to reproduce any copyrighted material contained within this report. 


\section{Contents}

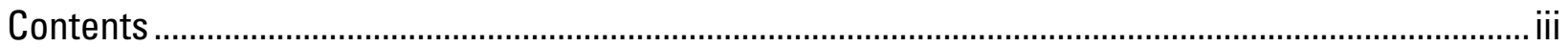

List of Appendixes ................................................................................................................... iv

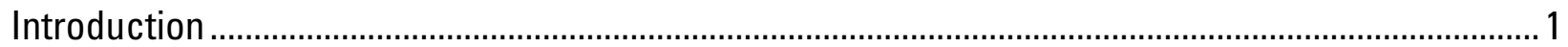

Figure 1. Diagram of the Western U.S. showing general area of the Intermountain West

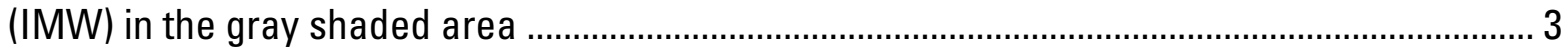

The Workshop Organization............................................................................................................. 4

First Day Activities .................................................................................................................. 4

Overview: Need for the Workshop and Goals (Anthony Crone, USGS) ...................................... 4

USGS External Grants in the IMW and the USGS National Seismic Hazard Maps

(Mark Petersen, USGS, IMW Regional Coordinator and Chief, National Seismic

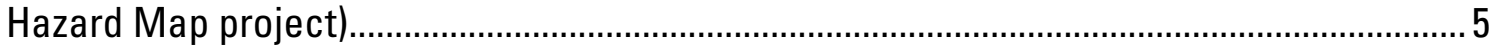

History and Utility of the Utah Quaternary Fault Parameters Working Group

(Appendix 3a) (William Lund, Utah Geological Survey, Cedar City, Utah)............................... 6

Hazardous Quaternary Faults in Arizona (Appendix 3b) (Phillip Pearthree, Arizona

Geological Survey, Tucson, Arizona) ...............................................................................

Hazardous Quaternary Faults in Colorado (Appendix 3c) (Vincent Matthews, State

Geologist, Colorado Geological Survey, Denver, Colorado) ................................................. 8

Hazardous Quaternary Faults in New Mexico (David Love, New Mexico Bureau of

Geology and Mineral Resources, Socorro, New Mexico) ................................................ 10

Hazardous Quaternary Faults in West Texas and Adjacent Areas (Michael Machette,

USGS, Denver, Colorado) ............................................................................................. 11

Discussion of Hazardous Quaternary Faults in the Southern IMW (Anthony Crone,

moderator, USGS, Denver, Colorado) ........................................................................... 12

Hazardous Quaternary Faults in Idaho (Appendix 3d) (William Phillips, Idaho Geological

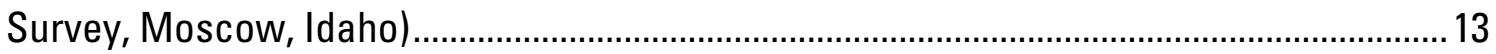

Hazardous Quaternary Faults in Montana (Appendix 3e) (Michael Stickney, Montana

Bureau of Mines and Geology, Butte, Montana) ............................................................ 15

Hazardous Quaternary Faults in the Yellowstone Area, Wyoming (Appendix 3f)

(Kenneth Pierce, USGS, Bozeman, Montana) ................................................................... 16

Hazardous Quaternary Faults in Southwest Wyoming (James McCalpin, GeoHaz

Consulting, Crestone, Colorado)...

Hazardous Quaternary Faults in Eastern Oregon (Appendix 3g) (Ian Madin, Department of Geology and Mineral Industries (DOGAMI), Portland, Oregon) .......................................18

Discussion of Hazardous Quaternary Faults in the Northern IMW (Anthony Crone, moderator, USGS, Denver, Colorado) .............................................................................. 19

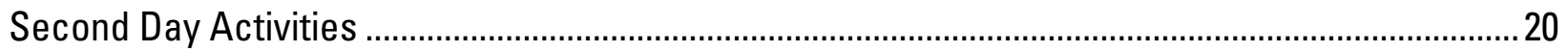

IMW Quaternary Faults in the National Seismic Hazard Maps (Appendix 3h)

(Kathleen Haller, USGS) ...........................................................................................20

Table 1. IMW faults that are currently included in the National Seismic Hazard maps...................20

Developing Criteria for Prioritizing Hazards Faults (Anthony Crone, USGS) ...............................23 
Table 2. Subjective criteria used to prioritize IMW faults

Prioritizing Faults for Future Studies (Anthony Crone, USGS) ......................................................24

Table 3. A proposed numerical rating system for IMW Quaternary faults.........................................2

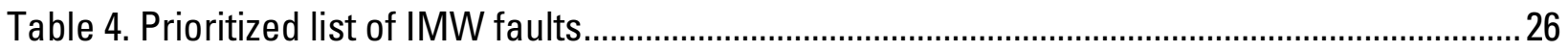

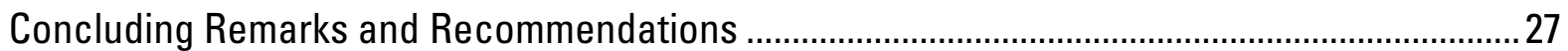

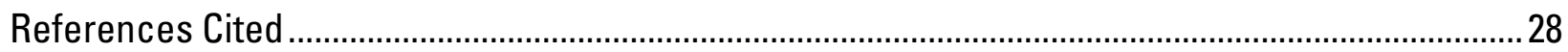

\section{List of Appendixes}

Appendix 1. Attendees of the IMW workshop "The evaluation of hazardous faults in the Intermountain West."

Appendix 2. Agenda for IMW workshop "The evaluation of hazardous faults in the Intermountain West."

Appendix 3. Selected PowerPoint presentations from the workshop

3a. Utah Quaternary Fault Parameters Working Group, William R. Lund, Utah

Geological Survey

3b. Particularly hazardous Quaternary faults in Arizona, Phillip A. Pearthree, Arizona Geological Survey.

3c. Hazardous Quaternary faults in Colorado, Vincent Matthews, Colorado

Geological Survey

3d. Hazardous Quaternary faults in Idaho, William Phillips and Roy Breckenridge, Idaho Geological Survey

3e. Hazardous Quaternary faults in Montana, Michael Stickney, Montana Bureau of Mines and Geology

3f. Hazardous Quaternary faults in the Yellowstone area, Kenneth Pierce, USGS.

3g. Hazardous Quaternary faults in Eastern Oregon, Ian Madin, Oregon Department of Geology and Mineral Industries

3h. IMW Quaternary faults in the USGS National Seismic Hazard maps, Kathleen Haller, USGS 


\title{
Evaluation of Hazardous Faults in the Intermountain West Region-
}

\section{Summary and Recommendations of a Workshop}

\author{
By Anthony J. Crone', Kathleen M. Haller', and Joseph Z. Maharrey'
}

\section{Introduction}

The U.S. Geological Survey's (USGS) Earthquake Hazards Program (EHP) has the responsibility to provide nationwide information and knowledge about earthquakes and earthquake hazards as a step to mitigating earthquake-related losses. As part of this mission, USGS geologists and geophysicists continue to study faults and structures that have the potential to generate large and damaging earthquakes. In addition, the EHP, through its External Grants Program (hereinafter called Program), supports similar studies by scientists employed by state agencies, academic institutions, and independent employers.

For the purposes of earthquake hazard investigations, the Nation is geographically subdivided into tectonic regions. One such region is the Intermountain West (IMW), which here is broadly defined as starting at the eastern margin of the Rocky Mountains in New Mexico, Colorado, Wyoming, and Montana and extending westward to the east side of the Sierra Nevada mountains in eastern California and into the Basin and Range-High Plateaus of eastern Oregon and Washington. The IMW contains thousands of faults that have moved in Cenozoic time, hundreds of which have evidence of Quaternary movement, and thus are considered to be potential seismic sources (fig. 1).

Ideally, each Quaternary fault should be studied in detail to evaluate its rate of activity in order to model the hazard it poses. The study of a single fault requires a major commitment of time and resources, and given the large number of IMW faults that ideally should be studied, it is impractical to expect that all IMW Quaternary faults can be fully evaluated in detail. A more realistic approach is to develop a prioritized list of IMW structures that potentially pose a significant hazard and to focus future studies on those structures. Accordingly, in June 2008, we convened a two-day workshop at the USGS offices in Golden, Colorado, to seek input from representatives of selected State Geological Surveys in the IMW and with knowledgeable regional experts to identify the important structures for future studies (Appendix 1). Such a priority list allows Program managers to guide the limited resources toward studies of features that are deemed to potentially pose the most serious hazards in the IMW. It also provides the scientific community with a list of structures to investigate because they are deemed to pose a significant hazard to population centers or critical structures.

The IMW encompasses all or large parts of 12 states including Arizona, New Mexico, extreme west Texas, Colorado, Utah, Nevada, eastern California, eastern Oregon, eastern

\footnotetext{
${ }^{1}$ U.S. Geological Survey, MS 966, P.O. Box 25046, Denver, Colorado 80225-0046
} 
Washington, Idaho, western Wyoming, and western Montana. In Utah, (Lund, 2005) and more recently in Nevada (dePolo, 2006), geoscientists have been taken steps to evaluate geologic data related to well-studied faults and to develop a statewide priority list of hazardous structures. In contrast to Utah and Nevada, the other IMW states contain substantially fewer Quaternary faults, so there have not been any previous efforts to develop similar priority lists. This workshop was organized to address this matter and create a more balanced perspective of priorities throughout the entire IMW region. Because working groups and workshops had already been convened to specifically deal with Quaternary fault priorities in Utah and Nevada, this workshop specifically emphasized structures outside of these two states. 
Figure 1. Diagram of the Western U.S. showing general area of the Intermountain West (IMW) in the gray shaded area. The IMW includes all or part of 12 states and extends into northern Mexico as the southern extension of the Rio Grande rift. Colored lines are Quaternary faults: red, historical; orange, latest Quaternary $(<15 \mathrm{ka})$; green, late Quaternary $(<130 \mathrm{ka}$; and blue, middle Quaternary ( $<750 \mathrm{ka}$ ) faulting. Data on age of faulting is from USGS Quaternary fault-and-fold database (http://earthquake.usgs.gov/regional/qfaults). Map created by S. Rhea, USGS.

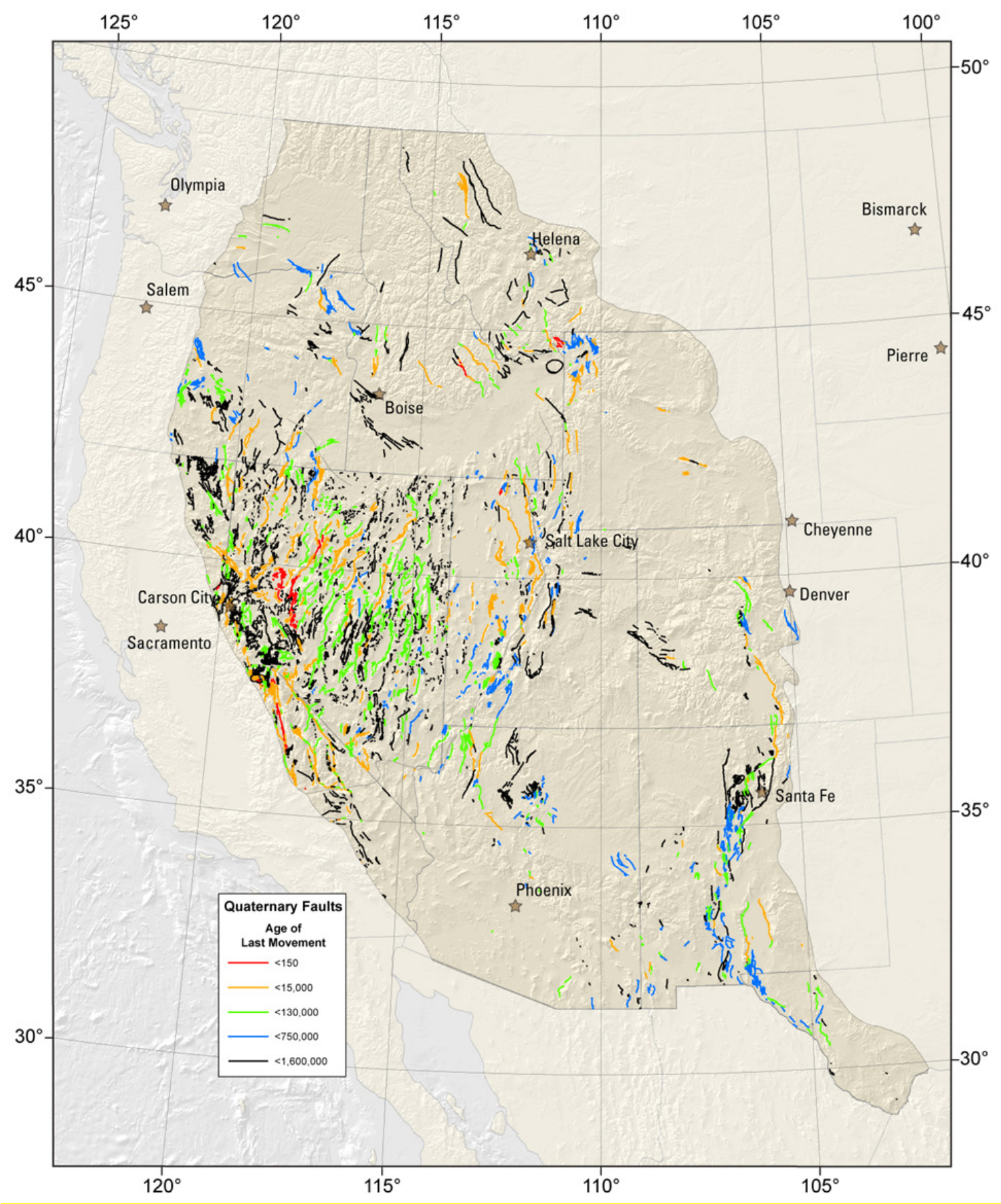




\section{The Workshop Organization}

A primary objective of the workshop was to solicit input, advice, and guidance from state geological surveys in the IMW regarding their perspective on hazardous structures in their respective states. The USGS recognizes the value and importance of working in partnership with state geological surveys and other agencies and organizations to assess seismic hazards and to evaluate hazardous faults. State surveys and agencies typically have close ties to their constituents and legislators, who look to the state surveys as a local source of earth-science information. Most actions and policies to deal with geologic hazards are implemented at the state level, so it is important that state geological surveys are engaged and participate in the process, including the starting point of developing research priorities. Most of the IMW states chose to send representatives, which contributed to the success of the workshop. The input from these representatives provided the foundation for discussions and the resultant priority list.

The first day of the workshop started with a few introductory presentations, but concentrated on overview presentations that summarized the status of knowledge and identified high-priority structures in each IMW state (excluding Utah, Nevada, and Washington) (Appendix 2). The second day emphasized the development of criteria to prioritize faults and discussions of how to apply those criteria. These discussions led to the development of some subjective criteria and an example of a possible weighted rating system. Eventually, the workshop participants individually ranked all of the structures discussed on the first day, and we compiled the cumulative ranking that is the basis for the ranked list presented in this report.

This report provides a summary of the presentations and discussions, and explains the evaluation process that led to the development of the priority list. For simplicity and to provide a succinct synopsis, we summarize many of the presentations and discussions as a series of bullets or numbered lists. This format captures the essential components of conversations and topics and allows us to efficiently encapsulate the salient points that arose. An underlying premise of discussions in the workshop was that we only discussed structures in the IMW region outside of the states of Utah and Nevada because those states already have processes in place to evaluate structures in their respective states. So unless specifically indicated, all subsequent references in this report to the IMW excludes structures in the states of Utah and Nevada.

\section{First Day Activities}

\section{Overview: Need for the Workshop and Goals (Anthony Crone, USGS)}

- The workshop provided a venue where geoscientists familiar with potentially hazardous faults in the IMW could collectively discuss aspects of these faults and identify structures that pose a significant threat and therefore warrant additional study.

- The mission of the USGS assigns it responsibility and oversight for seismic hazard studies and regional risk assessments throughout the IMW. However, the USGS recognizes and relies upon the expertise of and collaboration with other geoscientists from state geological surveys, academic institutions, and the private sector, so that we can collectively assemble the most complete knowledge of potentially hazardous faults in the IMW and use this knowledge as a basis for hazard assessments.

- The USGS National Seismic Hazard Maps incorporate a variety of data to evaluate the regional and local hazards. These sources include historical seismicity, Quaternary faults, and more recently, geodetic data. Our discussions in this workshop will focus on structures where 
geological information (or lack thereof) is relevant to assessing the hazard posed by specific structures. Thus, our discussions of structures should rely on ground-based information.

\section{USGS External Grants in the IMW and the USGS National Seismic Hazard Maps (Mark Petersen, USGS, IMW Regional Coordinator and Chief, National Seismic Hazard Map project)}

- For the purpose of this workshop, our focus is on the External Grants funding that is available for research on IMW structures in states other than Utah and Nevada. Funds through the External Grants part of the Earthquake Hazards Program (EHP) are distributed via a peerreview, competitive process, and historically it has been difficult to effectively compete for support for IMW studies outside of the high-hazard areas of Utah and Nevada. One goal of this workshop should be to identify structures in the IMW that pose a substantial hazard and therefore, warrant additional study. With such a priority list, proposals to study those structures may be able to compete more effectively with proposals to study IMW structures in Utah and Nevada.

- The current total budget for the USGS EHP's externally funded research has remained stagnant at about $\$ 6$ million annually for several years. At the Program level, funds for IMW studies are competing with research funds needed for studies elsewhere in the United States, including California, the Pacific Northwest, and the Central and Eastern United States, as well as topical studies. The IMW Region is viewed as having a moderate to high hazard, so the need for continuing studies in the region cannot be dismissed as unimportant.

- Geographically, the IMW Region is currently experiencing very rapid population growth in many areas and extensive changes in land use and development. Many metropolitan areas are expanding, with widespread construction and infrastructure development. Because of this growth and development, it is important to characterize the hazard as thoroughly as possible. The USGS recognizes this pressing need.

- The National Seismic Hazard maps are the main product that quantifies the level of seismic hazard nationwide, and this information affects building codes, which then affects development. Codes that are commensurate with the level of hazard need to be implemented in all parts of the IMW, including states other than Utah and Nevada.

- In Utah, the Utah Geological Survey arranges working groups, including a Quaternary Fault Parameters Working Group (UQFPWG), that meet on a regular basis to evaluate progress and to update priorities deemed to be the most important targets for future studies. The UQFPWG has been very effective at identifying and ranking structures that warrant additional study. A similar group was convened to carry out a similar function in the State of Nevada. However no such body exists in other IMW states, but perhaps it is advisable to establish such a regional IMW working group following the Utah model. This IMW Fault Working Group can serve the same role in the IMW as the UQFPWG serves in Utah. In the case of Utah, the input from this group provides valuable guidance that helps define priorities for research funding both within and outside of the USGS.

Question: What is the possibility of developing subregional working groups to identify and rank the hazard of specific structures? An example might be a working group focused on faults in the Yellowstone parabola.

Response: There are a variety of ways to subdivide the IMW region on the basis of groups of states, geography, or by geologic domains, such as, for example, a Rio Grande rift working group. This should be discussed and perhaps resolved in the course of this workshop. 
- The States of Utah and Nevada now host Web sites that contain information about Quaternary faults in their respective states and ranks priority targets for future studies. A similar type of Web site would be very useful for faults in other parts of the IMW, but similar to the working group(s), it is not clear how the area of coverage would be defined. Still, it is important that other parts of the IMW have a similar type of web presence containing information about understudied Quaternary faults.

- Attendee Comment: USGS seems like a logical host for such a Web site because, depending on how the area of interest is defined, it could cross state lines or it could encompass the entire IMW region. The USGS's mandate encompasses the entire region rather than being geographically confined to state boundaries.

- Response: The USGS is one option to host such a Web site, but there are other organizations such as the Association of State Geologists (ASG) or the Western States Seismic Policy Council (WSSPC) that could be candidates to host such a site.

- Attendee Comment: It is very important that results from this workshop are followed by a commitment to implement ideas and suggestions that are brought up in discussions. The USGS Geologic Hazards Team should spearhead the effort to expand the commitment for geographically broader studies in the IMW.

- When the workshop attendees advocate steps to promote studies in a geographically larger area, we need to consider relevant questions, such as:

1. If we rank structures in the IMW region, what are the important criteria to use?

2. What structures are important at the regional level? What structures do the individual states view as important from their perspective?

3. When fully organized, a goal might be to possibly fund two or three research projects in the IMW (outside of Utah and Nevada) annually, assuming that the projects are of sufficiently high quality to merit support. Ultimately research projects have to be scientifically strong and relevant to successfully acquire funding through the External Grants panel-review process.

\section{History and Utility of the Utah Quaternary Fault Parameters Working Group (Appendix 3a) (William Lund, Utah Geological Survey, Cedar City, Utah)}

- The ultimate goal of the Utah Quaternary Fault Parameters Working Group (UQFPWG) is to prioritize the structures that have the potential to generate damaging earthquakes.

- The original UQFPWG: the process that has led to the current UQFPWG began in 2003 when it was recognized that the currently available data and knowledge about Utah faults was insufficient to fully characterize the hazard. The Utah Geological Survey (UGS) received support to convene a panel of experts to systematically evaluate all of the paleoseismic trenching data on Utah faults and to develop consensus values for recurrence intervals and slip rates for each structure. The UQFPWG was composed of geologists and seismologists, many of whom have worked and are working in Utah and others who are not involved in Utah studies.

- During the initial meetings, it soon became apparent that, for even the best-studied faults, the data was still too sparse to perform statistical analyses. The original list of faults included the most obvious structures (for example, the Wasatch fault zone), and obscure faults that few knew about. At this time, much of the non-Wasatch fault data in Utah was derived from U.S. Bureau of Reclamation studies. 
- In 2003, only 16 percent of Utah's faults or fault segments had been studied in detail; 32 of 212 faults or fault segments. Much of these data were from studies at a single point along the fault. In view of the paucity of data, the working group was then asked to identify additional faults or fault segments that needed study and to prioritize those structures. By the end of 2004, the group identified 20 faults that needed further study, and the UGS focus is now narrowed to a subset of these structures.

- The UQFPWG today: The original working group has now evolved into three standing committees, one of which focuses on Quaternary faults. The UQFPWG is now composed of individuals who are working or have worked on Utah faults. Since 2005, it has been meeting annually to review the results of recently completed and ongoing studies, update consensus values on Utah faults, and revise recommendations for priority studies. The UGS also issues annual summaries of the working group's results on the UGS Web site to keep the public and scientific community informed of developments.

\section{Hazardous Quaternary Faults in Arizona}

(Appendix 3b)

\section{(Phillip Pearthree, Arizona Geological Survey, Tucson, Arizona)}

- The overall picture of hazardous faults in Arizona has not changed significantly since the first basic studies were conducted about 25 years ago. Most historical seismicity in Arizona is concentrated in the northern part of the state with a cluster of events in the Flagstaff area dating back to 1900 . However, the 1887 earthquake, which occurred just across the southern border in northern Mexico, is the largest historical earthquake to affect Arizona and possibly the entire IMW.

-Quaternary faults in Arizona:

1. Approximately $90-100$ faults have evidence of movement in the past $2 \mathrm{Ma}$.

2. Approximately 30 faults have been active in the past $130 \mathrm{ka}$.

3. Approximately 10 faults have been active in the past $15 \mathrm{ka}$.

4. Approximately 10 faults have been trenched.

5. Most faults in Arizona have estimated slip rates of less than $0.2 \mathrm{~mm} / \mathrm{yr}$.

Quaternary Faults in Arizona:

- Algodones fault (Yuma area)

1. It is a northwest-trending structure that follows a basement high, which separates adjacent deep basins. It offsets older Colorado River terraces; the fault has at least $15 \mathrm{~m}$ of vertical displacement in possible late Pleistocene fluvial deposits.

2. Trenched in $1970 \mathrm{~s}$

3. Most recent event is latest Pleistocene (11-15 ka), and fault has evidence of multiple late Quaternary displacements of $0.5-1.5 \mathrm{~m}$ in size.

4. The potential rupture length is unknown and may extend to the northwest of Yuma.

5. Because of its location adjacent to the Colorado River, liquefaction could be a serious problem in the Yuma area.

- Needles graben and folds-Mohave Valley (Arizona-Nevada)

1. A small graben on a Pleistocene fan was recognized in the $1970 \mathrm{~s}$, and the feature is listed in the USGS Quaternary fault-and-fold database. The structure is associated with a larger monoclinal fold, and more faults have been discovered recently.

2. A middle Pleistocene fan is vertically displaced more than $25 \mathrm{~m}$, and Pliocene river deposits are more strongly deformed. 
3. The structure is at least $20 \mathrm{~km}$ long.

4. The Arizona Dept. of Transportation (ADOT) is interested in this structure because, if it is a seismic hazard, the department may have to reroute a major highway.

- Big Chino fault zone (Prescott area)

1. This fault zone is located along the southwest margin of the Colorado Plateau

2. It is approximately $55 \mathrm{~km}$ long and may be segmented.

3. 20-m-high fault scarps are common on alluvial fans of probable Pleistocene age.

4. Trenching suggests three surface ruptures in the past $\sim 100 \mathrm{ka}$, and the youngest rupture is late Pleistocene in age.

5. Located north of the rapidly developing Prescott area.

- Lake Mary fault zone (Flagstaff area)

1. The fault zone is located in an area of abundant historical seismicity, and consist of many young faults, which indicate a fairly high regional hazard.

2. The Lake Mary fault zone is the longest fault zone in the area; it is defined by a 25-kmlong fault escarpment that vertically displaces a $6 \mathrm{Ma}$ basalt about $130 \mathrm{~m}$. These values yield a low long-term slip rate, but we do not have any good data on the age or length of the most recent surface rupture.

- Hurricane fault (Arizona-Utah)

1. The fault zone has a total length of about $250 \mathrm{~km}$ and extends northward into Utah, so it is a "shared" fault with the state of Utah.

2. It is defined by an impressive escarpment; an $850 \mathrm{ka}$ basalt is vertically displaced approximately $200 \mathrm{~m}$ and an approximately $100 \mathrm{ka}$ deposit is vertically displaced $20 \mathrm{~m}$.

3. The fault is likely divided into three segments that have ruptured in the Holocene and late Pleistocene (last $20 \mathrm{ka}$ ), but the length of individual ruptures are poorly known, as is information on recurrence intervals.

4. It poses a primary hazard to rapidly developing southern Utah, including the St. George area.

- Washington fault (Arizona-Utah)

1. This $65-\mathrm{km}$-long fault also extends into Utah and is marked by a locally impressive escarpment.

2. Recent studies suggest three late Quaternary surface ruptures, but important details, such as the slip rate, are not known.

3. Similar to the Hurricane fault, it is located near the rapidly developing parts of southern Utah, including the St. George area.

\section{Hazardous Quaternary Faults in Colorado}

(Appendix 3c)

(Vincent Matthews, State Geologist, Colorado Geological Survey, Denver, Colorado)

- Colorado is viewed as the least seismically hazardous state in the IMW region, yet it has more than 300 faults that offset Miocene deposits. It contains approximately 90 Quaternary faults.

- Colorado's Most Hazardous Quaternary Faults

- Golden fault

1. It is located along the Front Range in Golden, Colorado and adjacent to the Denver metropolitan area, but little is know about its Quaternary history. 
2. A HAZUS analysis indicates that a M6.5 earthquake would produce approximately $\$ 23$ billion in damage.

3. Quaternary movement on the fault was first suggested by Glenn Scott in the 1970s as a result of his trench located north of Golden, Colorado. The fault may have two periods of post-500 ka Quaternary movement. However many basic questions remain about the fault's location, dip direction, and times of past earthquakes.

4. Because of these questions, the fault needs a complete re-study to better understand its structure and hazard.

\section{- Rocky Mountain Arsenal faults}

The presence of faults was not recognized until fluid injection at the Rocky Mountain Arsenal triggered a series of moderate-magnitude earthquakes in the 1960s. They are not recognized at the surface, but imagery shows at least 11 lineaments in the area that have the same trend as the seismicity.

These faults are located in the Denver metropolitan area, so the exposure is high. Based on a HAZUS analysis, a M6.25 earthquake would produce approximately $\$ 15$ billion in damage.

These lineaments and structures need a complete re-study to better understand their hazard.

\section{- Rampart fault}

The Rampart faults is located near Colorado Springs.

Studies of a trench at a site near the U.S. Air Force Academy suggests two periods of Quaternary offset.

Eric Leonard reported about $190 \mathrm{~m}$ offset of the 37 Ma Wall Mountain tuff, but there are questions about the validity of the implications of this measurement.

A HAZUS analysis indicates that a M7.0 earthquake would produce approximately $\$ 23$ billion in damage.

\section{- Ute Pass fault}

This was one of eight Colorado faults that Glenn Scott originally documented as having evidence of Quaternary movement, but the Colorado Geological Survey has not been able to document the offset that Scott originally reported.

Nevertheless, this fault needs a thorough study to better understand its hazard and history of movement.

- Williams Fork faults

Following a regional study in 1993, Unruh and others suggested that this fault had the highest slip rate of any fault in Colorado. Subsequently, these faults were mapped in detail by Kirkham, and one strand was trenched but the results are uncertain. Additional sites need to be studied because only the fault's location and that it has Quaternary movement are certain.

The fault is a potential hazard because it is located in an area that is experiencing large population growth.

A HAZUS analysis indicates that a M6.5 earthquake would produce approximately $\$ 3.5$ billion in damage.

- Recent studies of other faults in Colorado have contributed new data

Sangre de Cristo fault zone: recent work by Anthony Crone and Michael Machette.

Southern Sawatch fault: evidence of possible liquefaction features. 
Mosquito fault: not many Quaternary deposits cross the fault. McCalpin recognized mainly landsliding along the fault trace.

Busted Boiler fault in southwestern Colorado. The Bureau of Reclamation recently excavated seven trenches across the fault.

Anton scarp: long, linear escarpment on the plains of eastern Colorado. The Colorado Geological Survey has completed four 125-m-long trenches across the scarp in recent years and have not found evidence of young faulting.

\section{Hazardous Quaternary Faults in New Mexico (David Love, New Mexico Bureau of Geology and Mineral Resources, Socorro, New Mexico)}

- Many faults in New Mexico are unstudied so it is difficult to select only five that warrant study. Understanding the seismic hazard in New Mexico requires a better understanding of a number of critical unknowns.

- The largest historical earthquake in New Mexico was approximately M6.0 in the Socorro area in 1906. There seemed to be an interval of relatively high seismicity between 1900 and 1910. Is there a correlation with the seismicity in the San Francisco area in the same era?

- New Mexico has approximately sixteen M2.0 earthquakes annually, three M3.0 earthquakes, and one M4.0 earthquake every 4.5 years. Historically, New Mexico has not been a seismically active state.

- The Anglo written record in New Mexico extends back to about 1850 and notes earthquakes in the Socorro area. The Pueblo era, which extends back about 500 years, does not contain records of large earthquakes in the state. Only one native tribe has a word for "earthquake," and interestingly, it is a tribe that is closest to the Pajarito fault.

- Statewide, there is no correlation between Quaternary faults and earthquakes.

- The primary region of concern is the north-south trending Rio Grande rift system that extends through central New Mexico that lies between the Colorado Plateau and the Southern Rockies. The rift system contains numerous faults and fault segments. Relay ramps link many of the faults, and some of the ramps seem to be active.

- In the central part of the rift, shallow magma bodies are associated with contemporary surface deformation.

- In the northern part of the rift, the Jemez caldera was a source of numerous tephras, which are useful for dating times of deformation.

- Pleistocene lakes were present in many places in and adjacent to the rift; deposits in these lakes and their shoreline deposits could provide good datums to constrain timing of deformation.

- In many places, 30-40 feet (9.1-12.2 m) of Holocene fill and eolian deposits are present throughout the rift and may obscure evidence of young faulting.

- Studies of faulting in the rift and along its margins is most important in New Mexico because the state's major population centers of Las Cruces, El Paso, Albuquerque, and Santa Fe are in the rift.

- New Mexico has a number of faults that are similar to the Pitaytachi fault in northern Sonora, Mexico, which produced the 1887 earthquake. By analogy, it may not be unreasonable to apply the intensity values from this earthquake to a number of New Mexico faults. 
New Mexico's Most Hazardous Quaternary Faults

- East Franklin Mountains fault

Including the Artillery Range, Organ Mountains, and San Andres fault that extend north of the East Franklin Mountains fault. The fault is now highly urbanized and therefore difficult to study.

- Albuquerque area faults

Sean Connell (NM Bureau of Mines and Geology) has constructed cross-sections that show a network of rift-related faults in the subsurface. A key question is: "Do these faults have the potential to generate damaging earthquakes?" The San Ysidro fault has about $30 \mathrm{~m}$ of paleosols exposed on the hanging wall of the fault; this could be evidence of a long record of stability and periodic movements.

- Pajarito fault system

The Pajarito fault system has been extensively studied, largely because of its proximity to Los Alamos National Laboratory, a critical facility. Many studies have examined the paleoseismology of the faults, but the hazard seems to increase as more data is acquired. The present data indicate three Holocene events and other older events. This is a complex system with many splays.

- Embudo-Santa Clara faults

These faults are located at the southern end of south Sangre de Cristo fault system and are part of the accommodation zone between the Sangre de Cristo and Pajarito fault systems in the northern Rio Grande rift.

\section{General comments by workshop participants:}

The East Heights area of Albuquerque encompasses a large number of unstudied faults in a highly populated area. Because of the urbanization, it is difficult to study these faults, but perhaps the easiest, most practical way is to use geophysical methods.

The Hubbell Springs fault is a complex network of faults in close proximity to Albuquerque. The entire system is more than $70 \mathrm{~km}$ long, at least $18 \mathrm{~km}$ wide, and is composed of multiple strands, so it is difficult to accurately determine the cumulative displacement across all strands, especially by conventional methods of surveying or trenching. LiDAR (Light Detection and Ranging) across the fault system might be the best and only accurate measure of cumulative offset across the entire system.

\section{Hazardous Quaternary Faults in West Texas and Adjacent Areas (Michael Machette, USGS, Denver, Colorado)}

- The USGS National Seismic Hazard maps incorporate 12 faults in the West Texas-southern New Mexico-Mexico area.

- Most faults in this area have low slip rates, and therefore, are viewed as low-hazard faults.

- Based on their lengths and other parameters, they could generate earthquakes in the magnitude range of 6.1-7.2.

West Texas and Adjacent Areas Most Hazardous Quaternary Faults

- East Franklin Mountains fault

The fault was initially trenched by Jeff Keaton in the early 1990s and subsequently by Jim McCalpin. Based on their studies, the most recent event occurred around $10 \mathrm{ka}$. The fault has an estimated slip rate of $0.18 \mathrm{~mm} / \mathrm{yr}$. Accurately dating the ages of paleoevents has been challenging because of the limestone terrain, but OSL may offer dating 
opportunities that were not available at the time of the earlier trenching studies. A key problem for studies in the area is to acquire access to promising paleoseismic sites. To date, generally no access has been granted for any type of detailed scientific investigation.

This is a long fault zone that extends through a region with a large population and a large number of poorly built structures. The public is generally unaware of the surrounding local earthquake hazard. Future fault studies in this area could potentially benefit by exploring possible cost-sharing with El Paso Electric Company (Texas).

\section{- Lobo Valley fault zone}

The fault zone is a basin-margin structure that is about $60 \mathrm{~km}$ long and is divided into four sections. The 1934 Valentine, Texas, earthquake is attributed to this fault zone. It is the easternmost structure of the southern Rio Grande rift. Access to sites along the fault is difficult. The risk associated with the fault zone is low because it is in a sparsely populated area.

\section{- Amargosa fault}

This fault is located entirely in northern Mexico, but it is a relatively long fault whose length suggests it has the potential to generate earthquakes possibly as large as M7.0. An event of this magnitude could cause significant shaking in El Paso, Texas, which is about 170 miles away. This structure is a basin-bounding fault that has an estimated slip rate of about $0.11 \mathrm{~mm} / \mathrm{yr}$ and an estimated recurrence interval of about $13 \mathrm{k} . \mathrm{y}$. The fault has not been studied in detail, so the quality of current estimates of slip rate and recurrence are not well constrained.

\section{Discussion of Hazardous Quaternary Faults in the Southern IMW (Anthony Crone, moderator, USGS, Denver, Colorado)}

The bullets below are synopses of comments made by workshop participants during this openforum session.

- The initial effort to stimulate in-depth paleoseismic investigations of the Wasatch fault zone in Utah was largely initiated by the USGS Earthquake Hazard Program's designation of the Wasatch Front as a target area of interest. The USGS dedicated people and resources to a multiyear research program, and this demonstration of interest in Utah's earthquake hazards motivated the Utah Geological Survey to become more active and better understand the seismic hazards within the state.

- Another big factor in the success of Quaternary fault studies in Utah is the fact that the Utah Geological Survey (UGS), as a principle stake-holder, provides cost-sharing for most studies. The willingness for the UGS to directly contribute to studies was an important and beneficial factor that increased their ability to secure outside grant money for research in Utah.

- Some workshop participants feel that, at times, the EHP seems to be stuck on the "risk" factor to significant populations as an overriding criteria when determining what faults warrant study. This results in other faults being ignored because the population at risk is not deemed to be high enough. Some faults in low-population areas could still be important to study on the basis of other factors or criteria.

- Participants recognize that it may be true that some faults in sparsely populated areas warrant study, but when a fault or fault zones poses a risk to population centers, this effectively draws attention to the structure. 
- Participants noted that the risk a fault poses to people should not be the only argument or criteria needed to justify a seismic-hazard investigation. Other factors exist as well, including the danger the fault poses to critical infrastructure.

- The regional strategy of the EHP is to designate high-priority study areas (for example, the Pacific Northwest, Southern California, and other) and to dedicate people and resources to these areas. Some participants suggested that the USGS identify the highest priority hazard areas, study them intensively for a finite period of time, and them move on to other areas.

- The initial paleoseismic and earthquake-hazard-related studies in Utah gave the IMW Region an identity and was a positive starting point. The UGS became a productive contributor that led to a strong Federal and State collaboration. The outstanding results show the benefits of this strong collaboration. Now it is time to begin studying other areas of the IMW region.

- The general message from Earthquake Program management still remains to focus on urbanized areas where the risk is high. This overall policy greatly influences where the majority of EHP funds are spent.

- To increase the amount and quality of earthquake-hazard related work in the IMW, the USGS should assist individual state agencies to identify meaningful research that will better constrain the state's earthquake hazards. This approach is a proven and effective method to improve general knowledge of earthquake hazards in the region.

- Given the limits of time, earthquake geologists, and resources, the USGS's Earthquake Hazards Group should consider aligning or partnering with other USGS teams and programs to pool individual resources, which in turn, could enable both groups to expand the breadth of current research activities.

- The net result of our discussions at this workshop should be to develop a list of priorities. We need to start the conversation about what are our, USGS, and IMW regional priorities should be, and ask, "What and where are the holes in our knowledge base within the region?" Next we should ask, "Why are there holes?"

\section{Hazardous Quaternary Faults in Idaho \\ (Appendix 3d) \\ (William Phillips, Idaho Geological Survey, Moscow, Idaho)}

- Geographically, Idaho is part of the IMW, but administratively from the USGS perspective, it is part of the Pacific Northwest region. So, EHP proposals for studies in Idaho are currently reviewed with those in the Pacific Northwest region of the EHP. However, we would prefer to be placed in the IMW region because of the greater geological similarities to IMW problems and geography.

- The nature of the seismicity in Idaho is the most complex in the entire IMW region. Idaho encompasses a variety of geological provinces: the Basin and Range, the Snake River Plain, the Yellowstone parabola, and the Yakima fold and fault belt.

- Seismicity patterns of note in Idaho include:

1. An area of diffuse seismicity between the Sawtooth fault in central Idaho and the Lost River-Lemhi-Beaverhead Ranges.

2. An area of diffuse seismicity near the McCall-Long Valley area north of Boise. 
3. Seismicity in Silver Valley of northern Idaho, near the Coeur d'Alene area. There is some question about whether this seismicity could be related to mining.

- Discrete patterns of faults in Idaho include:

1. Basin and Range faults in southeastern Idaho that are interrupted by Snake River basin.

2. Western Idaho faults.

3. Western Snake River Plain faults.

Idaho Quaternary Faults (not necessarily the most hazardous)

- The notion of studying low probability-high risk structures is very appealing for the state of Idaho.

\section{- Beaverhead fault}

This could be the most important poorly known fault in the state. It is included in the 2008 USGS National Seismic Hazard map. It is about $134 \mathrm{~km}$ long, is a southwestdipping normal fault, and is subdivided into six segments. It has an estimated slip rate of $0.12 \mathrm{~mm} / \mathrm{yr}$. It is a companion fault to the Lost River fault, which produced the 1983 Borah Peak earthquake. No paleoseismic trenches have been excavated on the fault, and there is no numerical dating of paleoevents. The estimated slip rate is based solely on scarp morphology. The National Seismic Hazard maps assign a maximum magnitude of M7.0, similar to the neighboring Lost River fault. It is close to INL (Idaho National Laboratory), a critical national facility.

\section{- Squaw Creek fault}

The Squaw Creek fault is the closest major fault near Boise, the state's largest city. It is an approximately 48-km-long, east-dipping normal fault. Based on its length, it could produce a M7.0 earthquake. It has an estimated slip rate of $0.1-0.2 \mathrm{~mm} / \mathrm{yr}$. One trench across the fault found evidence of multiple Holocene events and offset of the Mazama ash (about $7.6 \mathrm{ka}$; Zdanowicz and others, 1999). The fault is located in uplifted Columbia River basalts, which complicates paleoseismic studies.

\section{- Long Valley fault}

The Long Valley fault is not included in the 2008 National Seismic Hazard maps. This east-dipping normal fault is about $63 \mathrm{~km}$ long. It has an estimated slip rate of $0.1-0.2$ $\mathrm{mm} / \mathrm{yr}$. Although the fault has not been trenched, it is tentatively subdivided into two segments. In 2005, an earthquake swarm containing events in the M4 range occurred in the vicinity of the fault (Sprenke and others, 2007). Prehistoric movements have produced large scarps on Bull Lake-age deposits, but not on Pinedale-age deposits. The Long Valley fault is considered to be a high risk-low probability structure.

\section{- Heise-Grand Valley fault} Only the Wyoming part of the Heise-Grand Valley fault is included in the 2008 National Seismic Hazard. It is an approximately 136-km-long, east-dipping normal fault. Its length implies that it could produce a M7.0 earthquake. Geomorphically, the fault appears to become less active to the north-northwest in Idaho. It has been trenched at one location. It is near Palisades dam and reservoir, which is a critical source of water for aquifer recharge and irrigation. The Heise-Grand Valley fault is considered to be a high risk-low probability structure.

\section{- Sawtooth fault}

Developing studies of the Sawtooth fault report evidence of young displacements, but the results of this work have not been formally released. 
- Of the five faults listed above, only the first two are included in the National Seismic Hazard maps.

- The Idaho Geological Survey recommends that Idaho be placed in the IMW Region rather than the Pacific Northwest for the purposes of EHP proposals.

\section{Hazardous Quaternary Faults in Montana (Appendix 3e) (Michael Stickney, Montana Bureau of Mines and Geology, Butte, Montana)}

\section{- Mission fault}

The Mission fault is the best studied fault in Montana largely because of the efforts of the U.S. Bureau of Reclamation. It is approximately $102 \mathrm{~km}$ long and is divided into two segments. The northern segment does not have evidence of being active in Quaternary time, however, this part of the fault was overrun by late Quaternary ice sheets, so the evidence could have been obliterated by glacial processes. The southern segment has evidence of Holocene movement; the northern end of this segment is located south of Polson, Montana. The southern end of the south segment ends at the Lewis and Clark zone.

Bureau of Reclamation geologists excavated six trenches across the fault in 1992 and concluded that the maximum credible earthquake (MCE) for the Mission fault is Ms7.5, the age of the MRE was about $7.7 \pm 0.2 \mathrm{ka}$, and the average recurrence interval is $4-8 \mathrm{k} . \mathrm{y}$. Seismicity in the area of the fault is unusually deep; regionally, earthquakes are as deep as $20-30 \mathrm{~km}$. This might indicate that faults in this area could extend to greater depths than are typically considered, resulting in larger fault-plane areas that could rupture. The Mission fault is located near significant population centers and important structures, including 11 notable earth-filled dams, all of which are within $20 \mathrm{~km}$ of the fault. The city of Missoula is about $45 \mathrm{~km}$ south of the fault.

\section{- Canyon Ferry fault}

The 35-km-long Canyon Ferry fault is divided into two segments. It was trenched in 2002 by the U.S Bureau of Reclamation. This study concluded that no Holocene faulting had occurred, the age of the MRE is about $13 \pm 1 \mathrm{ka}$, and two or possibly three events occurred between 13-21 ka. This suggests possible clustering of events on the fault. The Bureau of Reclamation study estimated a MCE of M6.9-7.2 for the fault. The long-term slip rate is about $0.16 \mathrm{~mm} / \mathrm{yr}$, but the rate during a cluster of events could be $1.0 \mathrm{~mm} / \mathrm{yr}$. Recurrence intervals could be greater than 13 k.y., or as short as a few thousand years during an interval of clustered events.

The Canyon Ferry fault bounds the northeast side of a valley that is a structural graben; faults on the southwest side of the valley have not been studied.

\section{- Madison fault}

The 99-km-long Madison fault is divided into three sections, and a short part of the fault was reactivated during the 1959 Hebgen Lake earthquake. The fault has not been trenched. The area around the fault is largely aseismic, but a cloud of seismicity crosses the central part of the fault. However, focal mechanisms for earthquakes in this area suggest that they are not occurring on the Madison fault.

\section{- Hebgen and Red Canyon faults}

The Hebgen and Red Canyon faults ruptured during the 1959, M7.3 Hebgen Lake earthquake. Even though this earthquake occurred in a sparsely populated area, it caused 
29 fatalities and $\$ 11$ million in damage (equivalent to $\$ 78$ million in 2008).

In 2000, four trenches were excavated across the fault, but evidence of pre-1959 Holocene faults was reported in only one trench.

The focal mechanism for the 1959 event indicates slip on a fault that trends more eastwest than the scarps.

\section{- Centennial fault}

The 63-km-long Centennial fault is subdivided into three sections and has the highest slip rate $(1.3 \mathrm{~mm} / \mathrm{yr})$ of any fault in Montana. Lima Dam is as close as $15 \mathrm{~km}$ from the western end of the fault. The eastern end of the fault forms a " $T$ " intersection with the southern end of the Madison fault. A magnitude 4.4 earthquake in February 2006 occurred on the fault at a depth of about $14 \mathrm{~km}$. The fault has not been trenched or studied in detail.

- Red Rock fault

The Red Rock fault is a Basin and Range fault located north of the Snake River Plain in southern Montana. The 25-km-long Red Rock fault consists of two sections, the Timber Buttes and Sheeps Creek sections. A trench excavated on the Sheeps Creek section in 1986 indicated that the MRE occurred about $3 \mathrm{ka}$ and that two previous postglacial events also occurred on this section.

- High Risk-Low Probability Structures

Many Quaternary faults in Montana are unstudied, even the "well-known" faults. Several are in close proximity to Butte and other cities, where old masonry buildings would be damaged by moderate-magnitude events. Additional studies are likely to lead to new conclusions. Many Montana faults would be good candidates to study using LiDAR because of vegetated scarps, which conceal important details.

\section{Hazardous Quaternary Faults in the Yellowstone Area, Wyoming (Appendix 3f) (Kenneth Pierce, USGS, Bozeman, Montana)}

\section{- Yellowstone Parabola}

The parabola associated with migration of the Yellowstone hotspot is a controlling factor in the distribution of volcanic rocks and Quaternary faults in the region, including northwestern Wyoming. Faults in the front of the parabola commonly have large vertical offsets, but this may not necessarily be a true measure of the hazard. For example, the slip rates for the Teton and East Mount Sheridan faults are $1.3 \mathrm{~mm} / \mathrm{yr}$, and $1.4 \mathrm{~mm} / \mathrm{yr}$, respectively. Yet the Upper Yellowstone Valley and Eagle Bay faults are characterized by slip rates of 0.37 and $0.48 \mathrm{~mm} / \mathrm{yr}$, respectively. In addition, the Hoback fault may not have moved in the Quaternary, and may only have a slip rate of $0.07 \mathrm{~mm} / \mathrm{yr}$.

\section{- Teton fault}

The 50-km-long Teton fault is marked by very high scarps: as much as about $34 \mathrm{~m}$ high and about $20 \mathrm{~m}$ of surface offset. The Yellowstone ice cap may have affected late Quaternary slip on the fault. A recent study by Swiss researchers proposed that the ice cap flexed and compressed the crust, which affected movement on the fault. When the ice cap melted, the crustal relaxation resulted in a concentration of events in the time between $8 \mathrm{ka}$ and $12 \mathrm{ka}$. Therefore, assigning a single recurrence interval to the fault is complicated.

The cumulative vertical offset on the $4.5 \mathrm{Ma}$ Kilgore tuff yields a long-term slip rate that 
is similar to the postglacial rate. Submerged probable shorelines beneath the east side of Jackson Lake suggest as many as 10 postglacial surface-displacement events.

\section{- Faults East of the Yellowstone Parabola}

Several possibly active faults east of the Teton fault may define deformation at the leading edge of the Yellowstone parabola. They include: (1) a possible fault on the northeast side of Bobcat Ridge, (2) the Baldy Mountain fault, which is about $32 \mathrm{~km}$ east of the Teton fault and has a small cumulative offset but a high postglacial slip rate, and (3) the Factory Hill fault scarp.

\section{- East Mount Sheridan fault}

The East Mount Sheridan fault is marked by a scarp that has surface offsets of as much as $30 \mathrm{~m}$, and about $10 \mathrm{~m}$ on postglacial fans. The inferred slip rate of $1.4 \mathrm{~mm} / \mathrm{yr}$ based on these scarps may be overstated, but the postglacial rate is still relatively high.

\section{- Eagle Bay fault}

The Eagle Bay fault is located beneath Yellowstone Lake and could pose a hazard to Yellowstone National Park. It is in the Yellowstone caldera, where the depth of the brittle-ductile transition zone is shallow, possibly only $3 \mathrm{~km}$ deep. This shallow transition zone may mean that the fault poses a minimal hazard because of the relatively small fault area that could rupture.

\section{Hazardous Quaternary Faults in Southwest Wyoming (James McCalpin, GeoHaz Consulting, Crestone, Colorado)}

\section{- Generalizations about Southwestern Wyoming faults}

They are located in the Mesozoic-age Overthrust Belt of western Wyoming. Many of the faults in this area have relatively high slip rates, some of the highest in the IMW. The slip rates for most faults in the area are based on clustering of Holocene events. For example, the Bear River fault had surface-rupturing events at about $2.4 \mathrm{ka}$ and $4 \mathrm{ka}$. This implies a short-term recurrence interval on the order of a few thousand years. However, the total offset of late Pleistocene deposits is much less than the amount implied by this slip rate. So, there seems to be a high short-term rate and a lower long-term rate. Clustered behavior of southwest Wyoming faults explains the relatively high slip rates but relatively poor expression on the landscape. These relations indicate that the high slip rates have not been sustained for long periods of time and that the short-term slip rates do not accurately depict the fault's long-term behavior.

\section{- Rock Creek fault}

The slip rate for this fault is based on short recurrence during clustered events, not on a long-term average.

\section{- Bear River fault}

Appears to have a pattern of clustered earthquakes, with two late Holocene events, but no geomorphic evidence that this rate has been sustained throughout the Quaternary.

- Star Valley fault

Paleoseismic history of the fault indicated a bimodal pattern of earthquakes. At present, it appears that we have moved through an interval of clustered events and are now in a longer intra-cluster cycle.

- Grays River fault

Evidence of two clustered middle to late Holocene events preceded by longer time interval with no faulting. 


\section{Hazardous Quaternary Faults in Eastern Oregon (Appendix 3g)}

(Ian Madin, Department of Geology and Mineral Industries (DOGAMI), Portland, Oregon)

- Eastern Oregon is characterized by a low level of seismicity, but contains faults that clearly demonstrate evidence of Quaternary movement. Not only are these faults unstudied, they are neglected. A common problem with eastern Oregon faults is that they tend to be associated with bedrock scarps where the footwall consists of consolidated bedrock and deposits in the hanging wall consist of scarp colluvium and(or) basin fill. These relations make it difficult to measure stratigraphic offsets and to develop good paleoseismic histories.

\section{- Klamath graben faults}

Historical seismicity in the area is largely confined to the M5.9 and 6.0 Klamath Falls earthquakes, which occurred in 1993. Numerous faults have been mapped in the graben, many of which are in urbanized areas, but their paleoseismic histories remain unknown. There are a number of places where paleoseismic studies could be conducted, but most are difficult study sites because the scarps are in bedrock. The USGS parameters for the faults are estimates. A 40-ka ash, which was exposed in a building excavation, is cut by faults in the graben system. Many faults are exposed in gravel pits, but have not been studied in detail. No Mazama ash is present in the colluvium at the base of these bedrock scarps, which implies that movement is young, but remains undocumented.

\section{- Metolius-Sisters fault zone}

The Metolius-Sisters fault zone near Bend is not associated with much recorded seismicity but is composed of numerous fault strands. The current population in the area is on the order of 130,000-140,000, and is growing rapidly. There are abundant sites for paleoseismic studies, but they are difficult study sites because of bedrock scarps.

Evidence indicates that some faults have likely been active in the last few thousand years, but this is undocumented.

\section{- Grande Ronde Valley faults}

The Grande Ronde Valley is bounded by faults, but there is very little historical seismicity in the area and no record of damaging earthquakes. The aggregate population in the area is about 20,000. Similar to other eastern Oregon faults, there are abundant paleoseismic sites, but they are difficult to study because the scarps are in bedrock.

\section{- Wallula fault system}

The Wallula fault system in northeastern Oregon is near the tri-cities area of Walla Walla-Richland-Pendleton. It is located in an area of modest seismicity where an approximately M6.0 historical earthquake caused some damage. The area's aggregate population is $150,000-200,000$, and nearby major facilities include dams on the Columbia River and the Hanford site in nearby Washington. The fault has not been examined in enough detail to determine if suitable paleoseismic sites exist. The system contains numerous fault strands, some of which have evidence of latest Pleistocene or possibly Holocene movement.

\section{- Powder River Peninsula fault zone}

The Powder River Peninsula fault zone, on the Oregon-Idaho border, is in an area of modest recorded seismicity. The fault zone is near Brownlee Dam on the Snake River. The faults are short but appear to be fairly active. In most places, movement on the faults 
has juxtaposed bedrock against colluvium, but Bonneville-age flood gravels are clearly offset. There is no information on the ages of events, recurrence intervals, or estimated earthquake magnitudes.

- Value of LiDAR and IFSAR (Interferometric Synthetic Aperture Radar)

DOGAMI and the State of Oregon have and continue to acquire LiDAR data in many parts of the state. These data are extremely valuable for a variety of geological studies. For example, DOGAMI will acquire 5-m, "bare-earth" data in Malheur County for about $\$ 4,200$ per quadrangle. The cost is about $\$ 500$ per square mile to obtain 1-m resolution data.

\section{Discussion of Hazardous Quaternary Faults in the Northern IMW (Anthony Crone, moderator, USGS, Denver, Colorado)}

The bullets below are synopses of comments made by workshop participants during this openforum session.

- The next objective is to determine how to categorize faults in the IMW that warrant additional investigation. Should the IMW project and the USGS's priorities solely be focused on understudied faults near high population centers?

- In prioritizing study areas, the IMW region could benefit from: (1) having a defined set of criteria against which individual faults or fault zones could be evaluated, and (2) developing a list of faults or fault zones that meet those criteria and therefore are deemed to be priorities for study in the IMW.

- So what are the most important factors that contribute to the hazard and risk? Is it relatively high slip rates, say greater than $0.2 \mathrm{~mm} / \mathrm{yr}$ ? Is it structures that have short recurrence intervals, say less than 5 k.y.? Or is it the recency of last movement? Is it important and valuable to study low slip rate faults that are close to urban centers? Or is it important to study high slip rate faults in rural areas?

- The challenge is to develop and apply a simple set of criteria and weighting scheme that accounts for the level of hazard associated with a specific fault or fault zone.

- Another factor to consider in prioritizing structures is the impact or value of increasing our knowledge of a particular structure.

- Criteria used to define the hazard posed by a structure can be based on various qualities such as geologic domain, proximity to metropolitan regions, or on what is at risk by earthquakes on a fault. It is important to identify faults that are associated with high risk.

- We need to consider the consequences of low-probability events in high-risk areas.

- Some of the fundamental questions related to earthquake hazards are the accuracy of recurrence models, the amounts and sources of uncertainties in the data, and the effects of temporal clustering on defining the hazard.

- Lastly, we need to look at risk compared to the hazard. Are we at a minimally acceptable level of understanding the hazard and risk for all major urban population centers in the IMW? 


\section{Second Day Activities}

\section{IMW Quaternary Faults in the National Seismic Hazard Maps (Appendix 3h) (Kathleen Haller, USGS)}

- The current version of the USGS National Seismic Hazard maps incorporate more than 100 faults in the IMW region excluding those in Utah and Nevada (table 1).

- Most of the IMW faults characterized in the national seismic hazard maps are assigned low slip rates. However, most areas with high hazard reflect the high rates of seismicity rather than the increased hazard caused by proximity to fault(s). The hazard in the Intermountain Seismic Belt and the Central Nevada Seismic Belt is noteworthy. (App. 3h, image 1).

- The values for fault slip rates are typically based on only a few investigations for any individual fault (App. 3h, image 2).

- In the IMW, the calculated maximum magnitude is based on magnitude-length relations. Fifteen faults are long enough to assign maximum magnitudes greater than M7.3, which is the largest observed earthquake in the region (App. 3h, image 3).

- Following the general rule for the rest of the United States, less than one-quarter of the known Quaternary faults have the minimal data needed to characterize the fault as a earthquake source in a seismic hazard assessment (App. 3h, image 4).

Table 1. IMW faults that are currently included in the National Seismic Hazard maps.

[Faults are listed alphabetically for each state. Values in the Annual Rate (annualized rate of the maximummagnitude earthquake) column are exponential numbers such that $2.74 \mathrm{E}-04$ is equivalent to $2.74 \times 10^{-4}$. State abbreviations are: AZ, Arizona; CO, Colorado; ID, Idaho; MT, Montana; NM, New Mexico; OR, Oregon; TX, Texas; WY, Wyoming. —, no data.]

\begin{tabular}{|c|c|c|c|c|c|c|}
\hline Fault Name & State & $\begin{array}{l}\text { Slip rate } \\
(\mathrm{mm} / \mathrm{yr})\end{array}$ & $\begin{array}{c}\text { Dip } \\
\text { (degrees) }\end{array}$ & $\begin{array}{l}\text { Maximum } \\
\text { magnitude }\end{array}$ & $\begin{array}{c}\text { Annual } \\
\text { rate }\end{array}$ & $\begin{array}{l}\text { Recurrence } \\
\text { interval (ka) }\end{array}$ \\
\hline Algodones fault zone & $\mathrm{AZ}$ & 0.15 & 50 & 6.57 & $2.74 \mathrm{E}-04$ & 3.6 \\
\hline Aubrey fault zone & $\mathrm{AZ}$ & 0.018 & 50 & 7.18 & $1.35 \mathrm{E}-05$ & 74.1 \\
\hline Big Chino fault & $\mathrm{AZ}$ & 0.083 & 50 & 7.04 & $7.59 \mathrm{E}-05$ & 13.2 \\
\hline Dutchman Draw fault & $\mathrm{AZ}$ & 0.075 & 50 & 6.49 & $1.55 \mathrm{E}-04$ & 6.5 \\
\hline Hurricane fault zone (central) & $\mathrm{AZ}$ & 0.2 & 50 & 7.44 & $1.02 \mathrm{E}-04$ & 9.8 \\
\hline Hurricane fault zone (south) & $\mathrm{AZ}$ & 0.081 & 50 & 7.40 & $4.39 \mathrm{E}-05$ & 22.8 \\
\hline Sevier/Toroweap fault zone (south) & $\mathrm{AZ}$ & 0.11 & 50 & 7.50 & - & - \\
\hline Cheraw fault & $\mathrm{CO}$ & 0.15 & 60 & 7.00 & $1.15 \mathrm{E}-04$ & 8.7 \\
\hline Northern Sangre de Cristo fault & $\mathrm{CO}$ & 0.18 & 50 & 7.50 & - & - \\
\hline Southern Sawatch fault & $\mathrm{CO}$ & 0.062 & 50 & 6.99 & $6.19 \mathrm{E}-05$ & 16.2 \\
\hline Beaverhead fault & ID & 0.12 & 50 & 7.00 & - & - \\
\hline Big Flat-Jakes Creek fault & ID & 0.04 & 50 & 6.81 & $5.13 \mathrm{E}-05$ & 19.5 \\
\hline Cuddy Mountain-Lick Creek fault & ID & 0.05 & 50 & 6.79 & $6.67 \mathrm{E}-05$ & 15.0 \\
\hline Eastern Bear Lake fault & ID & 0.6 & 50 & 7.29 & $3.85 \mathrm{E}-04$ & 2.6 \\
\hline Lemhi fault & ID & 0.22 & 50 & 7.00 & - & - \\
\hline Lost River fault & ID & 0.15 & 45 & 7.00 & - & - \\
\hline Rush Peak fault & ID & 0.05 & 50 & 6.78 & $6.69 \mathrm{E}-05$ & 14.9 \\
\hline Squaw Creek fault & ID & 0.1 & 50 & 7.03 & $9.43 \mathrm{E}-05$ & 10.6 \\
\hline Blacktail fault & MT & 0.03 & 50 & 6.94 & $3.17 \mathrm{E}-05$ & 31.5 \\
\hline
\end{tabular}




\begin{tabular}{|c|c|c|c|c|c|c|}
\hline Canyon Ferry fault & MT & 0.13 & 50 & 6.92 & $1.43 \mathrm{E}-04$ & 7.0 \\
\hline Centennial fault & MT & 0.9 & 50 & 7.17 & $6.90 \mathrm{E}-04$ & 1.4 \\
\hline Emigrant fault & MT & 0.25 & 50 & 7.12 & $2.03 \mathrm{E}-04$ & 4.9 \\
\hline Georgia Gulch fault & MT & 0.031 & 50 & 6.42 & $7.14 \mathrm{E}-05$ & 14.0 \\
\hline Hebgen-Red Canyon fault & MT & 0.5 & 50 & 7.30 & $4.99 \mathrm{E}-05$ & 20.0 \\
\hline Helena Valley fault & MT & 0.01 & 50 & 6.60 & $1.75 \mathrm{E}-05$ & 57.1 \\
\hline Jocko fault & MT & 0.08 & 50 & 6.47 & $1.72 \mathrm{E}-04$ & 5.8 \\
\hline Madison fault & MT & 0.4 & 50 & 7.45 & $2.02 \mathrm{E}-04$ & 5.0 \\
\hline Mission fault & MT & 0.32 & 50 & 7.36 & $1.84 \mathrm{E}-04$ & 5.4 \\
\hline Red Canyon fault & MT & 0.5 & 60 & 6.60 & $7.44 \mathrm{E}-04$ & 1.3 \\
\hline Red Rock fault & MT & 0.5 & 50 & 6.73 & $7.29 \mathrm{E}-04$ & 1.4 \\
\hline Red Rock Hills fault & MT & 0.17 & 50 & 6.27 & $4.90 \mathrm{E}-04$ & 2.0 \\
\hline Sweetwater fault & MT & 0.04 & 50 & 6.38 & $9.64 \mathrm{E}-05$ & 10.4 \\
\hline Thompson Valley fault & MT & 0.08 & 50 & 6.22 & $2.45 \mathrm{E}-04$ & 4.1 \\
\hline Alamogordo fault & NM & 0.11 & 50 & 7.50 & $5.11 \mathrm{E}-05$ & 19.6 \\
\hline Black Mesa fault zone & NM & 0.02 & 50 & 6.54 & $3.81 \mathrm{E}-05$ & 26.2 \\
\hline Caballo fault & NM & 0.025 & 50 & 6.64 & $4.17 \mathrm{E}-05$ & 24.0 \\
\hline Calabacillas fault & NM & 0.0069 & 50 & 6.83 & $8.73 \mathrm{E}-06$ & 114.5 \\
\hline Cañones fault & NM & 0.02 & 50 & 6.81 & $2.56 \mathrm{E}-05$ & 39.1 \\
\hline County Dump fault & NM & 0.038 & 50 & 6.89 & $4.40 \mathrm{E}-05$ & 22.7 \\
\hline East Paradise fault zone & NM & 0.0096 & 50 & 6.38 & $2.33 \mathrm{E}-05$ & 42.9 \\
\hline Embudo fault & NM & 0.09 & 90 & 7.19 & $3.90 \mathrm{E}-05$ & 25.6 \\
\hline Gallina fault & NM & 0.02 & 50 & 6.93 & $2.17 \mathrm{E}-05$ & 46.1 \\
\hline Hubbell Springs fault & NM & 0.089 & 50 & 7.00 & $8.72 \mathrm{E}-05$ & 11.5 \\
\hline Jemez-San Ysidro fault & NM & 0.02 & 50 & 7.09 & $1.70 \mathrm{E}-05$ & 58.8 \\
\hline La Bajada fault & NM & 0.078 & 50 & 6.96 & $8.10 \mathrm{E}-05$ & 12.3 \\
\hline La Canada del Amagre fault zone & NM & 0.012 & 50 & 6.50 & $2.44 \mathrm{E}-05$ & 41.0 \\
\hline La Jencia fault & NM & 0.021 & 50 & 6.84 & $2.57 \mathrm{E}-05$ & 38.9 \\
\hline Lobato Mesa fault zone & NM & 0.0054 & 50 & 6.56 & $1.00 \mathrm{E}-05$ & 100.0 \\
\hline Nacimiento fault & NM & 0.02 & 50 & 7.30 & $1.27 \mathrm{E}-05$ & 78.7 \\
\hline Nambe fault & NM & 0.02 & 50 & 7.05 & $1.81 \mathrm{E}-05$ & 55.2 \\
\hline Organ Mountains fault & NM & 0.15 & 50 & 6.79 & $1.98 \mathrm{E}-04$ & 5.1 \\
\hline Pajarito fault & NM & NA & 50 & 7.05 & $9.90 \mathrm{E}-05$ & 10.1 \\
\hline Picuris-Pecos fault & NM & 0.05 & 50 & 7.39 & $2.78 \mathrm{E}-05$ & 36.0 \\
\hline Pojoaque fault & NM & 0.02 & 50 & 7.03 & $1.87 \mathrm{E}-05$ & 53.5 \\
\hline Puye fault & NM & 0.03 & 50 & 6.59 & $5.31 \mathrm{E}-05$ & 18.8 \\
\hline San Andres Mountains fault & NM & 0.1 & 50 & 7.50 & - & - \\
\hline San Felipe fault zone & NM & 0.043 & 50 & 6.97 & $4.42 \mathrm{E}-05$ & 22.6 \\
\hline San Francisco fault & NM & 0.063 & 50 & 6.76 & $8.77 \mathrm{E}-05$ & 11.4 \\
\hline Sawyer Canyon fault & NM & 0.024 & 50 & 6.15 & $8.24 \mathrm{E}-05$ & 12.1 \\
\hline Socorro Canyon fault zone & NM & 0.027 & 50 & 7.04 & $2.50 \mathrm{E}-05$ & 40.0 \\
\hline Southern Sangre de Cristo fault & NM & 0.13 & 50 & 7.42 & $6.83 \mathrm{E}-05$ & 14.6 \\
\hline Tijeras-Canoncito fault & NM & 0.09 & 90 & 7.29 & $3.40 \mathrm{E}-05$ & 29.4 \\
\hline Zia fault & NM & 0.038 & 50 & 6.84 & $4.68 \mathrm{E}-05$ & 21.4 \\
\hline Abert Rim fault & OR & 0.5 & 50 & 7.00 & $4.92 \mathrm{E}-04$ & 2.0 \\
\hline Battle Rock fault zone & OR & 0.1 & 50 & 7.00 & $9.73 \mathrm{E}-05$ & 10.3 \\
\hline Beaver Creek fault zone & OR & 0.2 & 50 & 6.52 & $3.96 \mathrm{E}-04$ & 2.5 \\
\hline Chemult graben fault system (east) & OR & 0.052 & 50 & 7.16 & $3.98 \mathrm{E}-05$ & 25.1 \\
\hline Chemult graben fault system (west) & OR & 0.44 & 50 & 7.21 & $3.13 \mathrm{E}-04$ & 3.2 \\
\hline Cottonwood Mountain fault & OR & 0.09 & 50 & 6.97 & $9.16 \mathrm{E}-05$ & 10.9 \\
\hline
\end{tabular}




\begin{tabular}{|c|c|c|c|c|c|c|}
\hline Goose Lake & OR & 0.1 & 50 & $\begin{array}{l}7.02 \\
6.85\end{array}$ & $\begin{array}{l}4.65 \mathrm{E}-05 \\
8.37 \mathrm{E}-05\end{array}$ & 21.5 \\
\hline Grant Butte fault & OR & 0.11 & 50 & 6.21 & $3.41 \mathrm{E}-04$ & 2.9 \\
\hline Juniper Mountain fault & OR & 0.01 & 50 & 6.53 & $1.94 \mathrm{E}-05$ & 51.5 \\
\hline Klamath graben fault system (east) & OR & 0.2 & 50 & 7.36 & $1.15 \mathrm{E}-04$ & 8.7 \\
\hline Klamath graben fault system (west) & OR & 0.16 & 50 & 7.06 & $1.42 \mathrm{E}-04$ & 7.0 \\
\hline Metolius fault zone & OR & 0.038 & 50 & 7.36 & $2.18 \mathrm{E}-05$ & 45.9 \\
\hline Paulina Marsh fault & OR & 0.29 & 50 & 6.26 & $8.41 \mathrm{E}-04$ & 1.2 \\
\hline Pine Valley graben fault system, Brownlee section & OR & 0.008 & 50 & 6.56 & $1.50 \mathrm{E}-05$ & 66.7 \\
\hline Pine Valley graben fault system, Halfway-Posey Valley section & OR & 0.008 & 50 & 6.91 & $8.96 \mathrm{E}-06$ & 111.6 \\
\hline Santa Rosa fault system & OR & 0.13 & 50 & 7.50 & $5.39 \mathrm{E}-05$ & 18.6 \\
\hline Sky Lakes fault zone & OR & 0.28 & 50 & 7.08 & $2.45 \mathrm{E}-04$ & 4.1 \\
\hline Southeast Newberry fault zone & OR & 0.51 & 50 & 7.20 & $3.74 \mathrm{E}-04$ & 2.7 \\
\hline Steens fault zone & OR & 0.3 & 50 & 7.50 & $1.24 \mathrm{E}-04$ & 8.1 \\
\hline Tule Springs Rim fault & OR & 0.1 & 50 & 6.90 & $1.12 \mathrm{E}-04$ & 8.9 \\
\hline Wallowa fault & OR & 0.14 & 50 & 7.08 & $1.21 \mathrm{E}-04$ & 8.3 \\
\hline Warner Valley faults (east) & OR & 0.11 & 50 & 7.50 & - & - \\
\hline Warner Valley faults (west) & OR & 0.11 & 50 & 6.99 & $1.08 \mathrm{E}-04$ & 9.3 \\
\hline Winter Rim fault system & OR & 0.43 & 50 & 7.19 & $3.18 \mathrm{E}-04$ & 3.1 \\
\hline Acala fault & $\mathrm{TX}$ & 0.088 & 50 & 6.09 & $3.27 \mathrm{E}-04$ & 3.1 \\
\hline Amargosa fault & $\mathrm{TX}$ & 0.11 & 50 & 7.22 & $7.77 \mathrm{E}-05$ & 12.9 \\
\hline Arroyo Diablo fault & $\mathrm{TX}$ & 0.013 & 50 & 6.41 & $3.03 \mathrm{E}-05$ & 33.0 \\
\hline Caballo fault & $\mathrm{TX}$ & 0.11 & 50 & 6.97 & $1.12 \mathrm{E}-04$ & 8.9 \\
\hline Campo Grande fault & $\mathrm{TX}$ & 0.048 & 50 & 7.00 & $4.67 \mathrm{E}-05$ & 21.4 \\
\hline East Baylor Mountain - Carizzo Mountain fault & TX & 0.008 & 50 & 6.96 & $8.22 \mathrm{E}-06$ & 121.7 \\
\hline East Franklin Mountains fault & TX & 0.1 & 50 & 7.03 & $9.40 \mathrm{E}-05$ & 10.6 \\
\hline East Sierra Diablo fault & TX & 0.02 & 50 & 6.86 & $2.42 \mathrm{E}-05$ & 41.3 \\
\hline West Delaware Mountains fault zone & TX & 0.024 & 50 & 6.70 & $3.65 \mathrm{E}-05$ & 27.4 \\
\hline West Eagle Mountains-Red Hills fault & TX & 0.013 & 50 & 6.69 & $2.00 \mathrm{E}-05$ & 50.0 \\
\hline West Indio Mountains fault & TX & 0.044 & 50 & 6.66 & $7.13 \mathrm{E}-05$ & 14.0 \\
\hline West Lobo Valley fault zone & TX & 0.034 & 50 & 7.15 & $2.69 \mathrm{E}-05$ & 37.2 \\
\hline Bear River fault zone & WY & 1.5 & 50 & 6.90 & $4.35 \mathrm{E}-04$ & 2.3 \\
\hline Eagle Bay fault & WY & 0.48 & 50 & 6.82 & $6.13 \mathrm{E}-04$ & 1.6 \\
\hline East Mount Sheridan faults & WY & 1.4 & 50 & 6.64 & $2.32 \mathrm{E}-03$ & 0.4 \\
\hline Grand Valley fault & WY & 1.1 & 50 & 7.10 & $9.31 \mathrm{E}-04$ & 1.1 \\
\hline Greys River fault & WY & 0.62 & 50 & 7.05 & $5.64 \mathrm{E}-04$ & 1.8 \\
\hline Hoback fault & WY & 0.071 & 50 & 6.56 & $1.33 \mathrm{E}-04$ & 7.5 \\
\hline Rock Creek fault & WY & 1.7 & 50 & 6.95 & $1.79 \mathrm{E}-03$ & 0.6 \\
\hline Teton fault & WY & 1.3 & 50 & 7.16 & $9.96 \mathrm{E}-04$ & 1.0 \\
\hline Upper Yellowstone Valley faults & WY & 0.37 & 50 & 6.54 & $7.06 \mathrm{E}-04$ & 1.4 \\
\hline
\end{tabular}




\section{General comments by workshop participants:}

It is worth thinking about how the National Seismic Hazard maps might change if we had more detailed studies of faults in the IMW. What would a modern version of the maps look like if they had been generated prior to the 1959 Hebgen Lake earthquake? Would the hazard in this area be comparable?

The issue about how to deal with fault length in the hazard maps is not a simple one. For long fault systems, it is clear that the entire zone does not rupture during a single event. Ideally, we would like to have the knowledge to subdivide those faults into discrete rupture segments, but we do not yet know how to accurately identify rupture segments and the issue of segmentation is not well understood. For example, what is the threshold fault length above which a fault should be treated as being segmented?

\section{Developing Criteria for Prioritizing Hazards Faults (Anthony Crone, USGS)}

- What are the characteristics that identify hazardous faults?

1. High slip rates: generally $>0.2 \mathrm{~mm} / \mathrm{yr}$, which would produce approximately 3 -m-high scarps in 15 ka deposits.

2. Short recurrence intervals: $<5 \mathrm{ka}$.

3. Recency of last movement: should faults that have evidence of movement in the Holocene be considered hazardous? or middle Holocene? or even younger?

- How should we define risk?

1. Should risk be defined by the proximity of a fault to a significant population or infrastructure? Should risk be defined by the proximity to the epicenter of a significant historical earthquake?

2. Should it be defined by the potential for serious damage to critical facilities (such as dams, power plants, nuclear facilities, critical transportation facilities)?

- How do we:

1. Quantify "proximity" in terms of measureable distances?

2. Determine what constitutes a "significant" population?

3. Define a "critical facility?"

- Other issues to consider

1. What is the impact of increased knowledge for a specific structure?

a. Will better data significantly modify our understanding of the level of hazard posed by a specific structure?

Example: East Mt. Sheridan fault, Wyoming has a recurrence interval of $400 \mathrm{yrs}$.

b. Will more data better define the risk to people or critical structures?

Example: South Sangre de Cristo fault, New Mexico

c. Will obtaining data on previously unstudied structures improve the National Seismic Hazard maps?

Example: Sawtooth fault, Idaho

2. Will urbanization and development destroy suitable study sites and eliminate the possibility of acquiring critical data?

Example: East Franklin Mountains. fault

- The Challenge: to develop and apply a simple scheme that accounts for the level of hazard and the degree of risk for a fault based on its distance to populated areas or to critical facilities as well as other criteria. 
- Considerable discussion led to a list of subjective criteria that can be used to prioritize IMW faults (table 2). Workshop participants recognized the difficulty in developing and applying a set of balanced, consistent, and widely accepted numerical values for each of the criteria without an extensive deliberation, review, and vetting. This would require an exhaustive process that was far beyond the scope of this workshop. Nevertheless, it was worthwhile having the criteria list as a reminder of the factors to consider when evaluating faults.

Table 2. Subjective criteria used to prioritize IMW faults

[Not all criteria necessarily apply to all structures that were considered in the final ranking. The numerical sequence in the list does not imply differing levels of importance for the individual criteria]

1. Proximity to population centers.

2. Proximity to critical facilities.

3. Scientific merit relative to general seismic hazard issues. Study of a structure will yield a better understanding of how to evaluate hazards and hazard models.

4. Influence on National Seismic Hazard Maps. Study of the structure will eliminate suspect features from the hazard maps or will result in particularly hazardous faults and folds being included in future versions of the maps.

5. Improvement in fault parameters. Study of a structure will resolve major questions about its rate of activity or about uncertainties in important fault parameters, such as slip rate, magnitude, recurrence interval, or time since the last event.

6. Urbanization (or other factors) is eliminating suitable sites, and if the structure is not studied soon, then opportunities will be permanently lost.

7. Level of knowledge about a structure. The level of knowledge of a structure is good, fair, poor, or unknown. A modest amount of study may significantly improve our level of knowledge for poor or unknown faults.

8. HAZUS as guide to estimating potential losses. HAZUS is a somewhat independent way of characterizing the possible impact a structure may have on existing infrastructure and populations.

\section{Prioritizing Faults for Future Studies (Anthony Crone, USGS)}

- A number of workshop participants advocated dividing the IMW region into two parts: a Northern IMW working group and a Southern IMW working group. The rationale for this was that, in many aspects, the nature of the problems and structures confronted by the northern and southern IMW states were similar. The Utah Geological Survey indicated that it would be willing to provide support and act as an observer to guide the development of these working groups.

- The discussion about criteria and ways to rank structures prompted Jim McCalpin to spontaneously develop and present a prototype numerical rating system that could be used as a model ranking tool (table 3 ). This ranking system is simple and captures key aspects of the hazard and risk associated with structures, but the subjective weighting factors for each of the input parameters are difficult to quantify. 
Table 3. A proposed numerical rating system for IMW Quaternary faults.

[System was proposed by J. McCalpin as a possible methodology to apply to IMW faults]

Rating $=\mathrm{W}_{1} \mathbf{P}+\mathrm{W}_{2} \mathbf{S R}+\mathrm{W}_{3} \mathbf{R}+\mathrm{W}_{4} \mathbf{U}+\mathrm{W}_{5} \mathbf{I}+\mathrm{W}_{6} \mathbf{D}$

Where: $\mathrm{W}_{\mathrm{x}}$ are weights (integers between 1 and 10; 1 indicates low importance and 10 indicates high importance)

Bold letters are the Class values for each input parameter, where Class $1=1$, Class $2=2$, Class $3=3$

\begin{tabular}{lccc}
\hline \multicolumn{1}{c}{ Input Parameter } & Class 1 & Class 2 & Class 3 \\
\hline $\mathbf{P}=$ population of close city $(<100 \mathrm{~km})$ & $<20,000$ & $20,000-$ & $>200,000$ \\
or critical facility type & & 200,000 & \\
$\mathbf{S R}=$ slip rate (mm/yr) & $<0.1$ & $0.1-0.2$ & $>0.2$ \\
$\mathbf{R}=$ rapid urbanization of fault trace & low & med & high \\
$\mathbf{U}=$ uncertainty in current source & low & med & high \\
parameters & low & med & high \\
$\begin{array}{l}\text { I=impact on National Map of } \\
\text { changing fault's parameters (or of }\end{array}$ & & & \\
$\begin{array}{l}\text { adding a fault) } \\
\mathbf{D}=\text { distance from fault to city/critical } \\
\text { facility }(\mathrm{km})\end{array}$ & $>100 \mathrm{~km}$ & $20-100 \mathrm{~km}$ & $<20 \mathrm{~km}$ \\
\hline
\end{tabular}

Subjective relative weights:

$\mathrm{W}_{1}=10$ (population)

$\mathrm{W}_{2}=1$ (Slip rate)

$\mathrm{W}_{3}=4$ (rapid urbanization)

$\mathrm{W}_{4}=3$ (uncertainty in parameters)

$\mathrm{W}_{5}=5$ (impact of change)

$\mathrm{W}_{6}=7$ (distance fault to city)

Example 1: high-rated fault, East Franklin Mountains, Texas

Rating $=10 \mathrm{P}+1 \mathrm{SR}+4 \mathrm{R}+3 \mathrm{U}+5 \mathrm{I}+7 \mathrm{D}$

$=10(3)+1(2)+4(3)+3(2)+5(2)+7(3)=\mathbf{8 4}$

Example 2; low-rated fault, Rock Creek fault, Wyoming

Rating $=10 \mathrm{P}+1 \mathrm{SR}+4 \mathrm{R}+3 \mathrm{U}+5 \mathrm{I}+7 \mathrm{D}$

$=10(1)+1(3)+4(1)+3(3)+5(3)+7(1)=\mathbf{4 8}$

- Ultimately, we applied an "expert opinion" strategy to develop a ranked list of IMW structures. We compiled a master list composed of all the structures that were noted in the state-by-state presentations. The master list contained two fields: a "Top-ten" ranking and a "Priority category."

- Each workshop participant was given a copy of the list and asked to objectively rank their "Top-ten" structures. The participant's highest priority structure was given a score of 10 , the next highest priority, a score of 9 , and third-highest, a score of 8 . They continued this scoring sequence such that their 10th-highest priority structure was given a score of 1 .

- Participants were also asked to identify structures that might not be part of their "Top-ten" list, but seems significant enough to study because of other specific factors. We did not 
apply any scoring to this "Priority Category," but included it only as a means for recognizing a structure warranted more study. We did keep a tally of the number of times a specific structure was denoted in this Priority Category and list it in table 4.

- We then added the scores in the "Top-ten" category from all of the individual assessments to develop the ranked list. We also made a tally of the number of times a structure was checked as a "Priority" structure. The results are presented in table 4.

- Interestingly, each IMW state had at least one structure in the ten highest priority faults. Proximity to significant population centers appears to be an important trait shared by most of the high-scoring faults, but the Centennial fault is located in a sparsely populated part of southern Montana. This indicates that proximity of population was not always required for a structure to have a high ranking.

Table 4. Prioritized list of IMW faults.

[See text for explanation of how list was developed. Names of the 10 highest scoring structures are shown in bold type. Numbers listed in the Top 10 column are cumulative points totaled from all workshop participants; see text for explanation of how structures were scored. Numbers in Priority category are the total number of participants who concluded that the structure was not part of their "Top ten" list, but should have priority consideration for future study. State abbreviations are same as in table 1]

\begin{tabular}{lll} 
Structure name & $\begin{array}{l}\text { Cumulative Points from the } \\
\text { sum of "Top ten rankings" }\end{array}$ & $\begin{array}{l}\text { Priority } \\
\text { category }\end{array}$ \\
\hline
\end{tabular}

$\begin{array}{llcl}\text { 1. } & \text { E. Franklin Mtns. fault, NM and TX } & 147 & 1 \\ \text { 2. } & \text { Albuquerque area faults, NM } & 115 & 1 \\ \text { 3. Golden fault, CO } & 68 & 6 \\ \text { 4. Algodones fault, AZ } & 56 & 2 \\ \text { 5. Hurricane fault, AZ and UT } & 52 & 2 \\ \text { 6. Centennial fault, MT } & 47 & 4 \\ \text { 7. } \text { Rampart Range fault, CO } & 46 & 3 \\ \text { 8. } \text { Teton fault, WY } & 43 & 3 \\ \text { 9. Metolius-Sisters faults, OR } & 38 & 3 \\ \text { 10. Squaw Creek fault, ID } & 36 & 4 \\ \text { 11. Klamath graben faults, OR } & 34 & 5 \\ \text { 12. Washington fault, AZ and UT } & 29 & 3 \\ \text { 13. Mission fault, MT } & 27 & 4 \\ \text { 14. Rocky Mtn. Arsenal fault, CO } & 26 & 2 \\ \text { 15. Beaverhead fault, ID } & 24 & 6 \\ \text { 16. Sawtooth fault, ID } & 20 & 5 \\ \text { 17. Long Valley fault, ID } & 18 & 5 \\ \text { 18. Canyon Ferry fault, MT } & 17 & 3 \\ \text { 19. Madison fault, MT } & 16 & 5 \\ \text { 20. Wallula fault, OR } & 15 & 2 \\ \text { 21. Embudo-Santa Clara fault, NM } & 13 & 4 \\ \text { 22. Hebgen/Red Canyon fault, MT } & 13 & 1 \\ \text { 23. Powder River Peninsula fault, OR } & 9 & 1\end{array}$


24 East Mt. Sheridan fault, WY

25. Williams Fork fault, $\mathrm{CO}$

26. Grays River fault, WY

27. Pajarito fault, NM

28. Big Chino, AZ

29. Heise-Grand Valley faults, ID

30. Amargosa fault, northern Mexico

31. Lake Mary fault zone, AZ

32. Bear River fault, WY

33. Needles graben and fold, AZ

34. Star Valley fault, WY

35. Red Rock fault, MT

36. Hoback fault, WY

37. Eagle Bay fault, WY

38. Grande Ronde Valley fault, OR

39. Ute Pass fault, $\mathrm{CO}$

40. Rock Creek fault, WY

41. Hubble Springs fault system, NM

323

42. Lobo Valley fault, TX

\section{Concluding Remarks and Recommendations}

- Workshop participants collectively agreed that an IMW Web site be developed but did not develop a consensus on whether the IMW region should be divided into a Northern and a Southern region, with each region having its own working group. There was also no consensus on which agency or organization would best host an IMW Web site.

- Some participants proposed that individual IMW states study, manage, and update their data on Quaternary faults and that representatives from IMW states periodically meet to discuss progress on hazardous fault studies.

- The USGS welcomed assistance from and partnering with state geological surveys to manage and fine-tune the Quaternary fault data, which can then contribute to improved National Seismic Hazard maps.

- Some participants advocated that future Requests for Proposals from the EHP External Grants Program contain language that specifically acknowledges the desire to support worthy IMW proposals in states outside of Utah and Nevada.

- Workshop participants favored convening a similar meeting of IMW states every two to three years to evaluate progress on fault studies and to update a list of priority structures 


\section{References Cited}

dePolo, C.M., 2006, Estimating uncertainties of seismic hazard parameters for Nevada faults, formations of a Nevada Quaternary fault working group, and gaining consensus fault parameters: U.S. Geological Survey Earthquake Hazards Program Final Technical Report, Grant Award No. 06HQAG0126, 189 p. (available at:

http://earthquake.usgs.gov/research/external/research.php?yearID=2006\&pi=\&regionID=4\&a ward $=$ \&keyword $=$ \&institution $=\&$ submit $=$ Find + Projects $)$

Lund, W.R., 2005, Consensus preferred recurrence-interval and vertical slip-rate estimatesReview of Utah paleoseismic-trenching data by the Utah Quaternary Fault Parameters Working Group: Utah Geological Survey Bulletin 134, 114 p.

Petersen, M.D., Frankel, A.D., Harmsen, S.C., Mueller, C.S., Haller, K.M., Wheeler, R.L., Wesson, R.L., Zeng, Yuehua, Boyd, O.S., Perkins, D.M., Luco, Nicolas, Field, E.H., Wills, C. J., and Rukstales, K.S., 2008, Documentation for the 2008 update of the United States National Seismic Hazard maps: U.S. Geological Survey Open-File Report 2008-1128, 61 p. (available at: http://pubs.usgs.gov/of/2008/1128/)

Sprenke, K.F., Stickney, M.C., and Peterson, J. L., 2007, The Alpha earthquake swarm, Valley County, Idaho: Idaho Geological Survey Staff Report 07-3, 47 p. (available at: http://www.idahogeology.org/PDF/Staff_Reports_(S)/2007/AlphaSwarmdraft4_StaffReport_0 7-3.pdf

Zdanowicz, C.M., Zielinski, G.A., and Germani, M.S., 1999, Mount Mazama eruptionCalendrical age verified and atmospheric impact assessed: Geology, v. 27, no. 7, p. 621-624. 


\section{Appendixes}

Appendix 1. Attendees of the IMW workshop "The evaluation of hazardous faults in the Intermountain West."

Larry W. Anderson

U.S. Bureau of Reclamation

Denver, CO 80225-0007

Richard W. Briggs

U.S. Geological Survey

Denver, CO 80225-0046

Anthony J. Crone

U.S. Geological Survey

Denver, CO 80225-0046

Kathleen M. Haller

U.S. Geological Survey

Denver, CO 80225-0046

Robert M. Kirkham

Consulting Geologist

Alamosa, CO 81101

David W. Love

New Mexico Bureau of Mines \& Geol.

Socorro, NM 87801-4796

William R. Lund

Utah Geological Survey

Cedar City, UT 84720

Michael N. Machette

U.S. Geological Survey

Denver, CO 80225-0046

Joseph "Zeb" Z. Maharrey

U.S. Geological Survey

Denver, CO 80225-0046

Ian P. Madin

Oregon Dept. of Geol \& Min. Indust.

Portland, OR 97232

Vincent Matthews

Director, Colorado Geological Survey

Denver, CO 80203

James P. McCalpin

GEO-HAZ Consulting, Inc.

Crestone, CO 81131
Alan R. Nelson

U.S. Geological Survey

Denver, CO 80225-0046

Susan S. Olig

URS Corporation

Oakland, CA 94612

Dean Ostenna

William Lettis \& Associates

Golden, CO 80401

Phillip A. Pearthree

Arizona Geological Survey

Tucson, AZ 85701

Stephen F. Personius

U.S. Geological Survey

Denver, CO 80225-0046

William M. Phillips

Idaho Geological Survey

Moscow, ID 83844-3014

Mark D. Petersen

U.S. Geological Survey

Denver, CO 80225-0046

Kenneth L. Pierce

U.S. Geological Survey (retired)

Bozeman, MT 59717-3492

Michael C. Stickney

Montana Bureau of Mines \& Geology

Butte, MT 59701-8997

Seth J. Wittke

Wyoming State Geological Survey

Laramie, WY $82073^{2}$

\footnotetext{
${ }^{2}$ Representative for the State of Wyoming but unable to attend because of a schedule conflict
} 
Appendix 2. Agenda for IMW workshop "The evaluation of hazardous faults in the Intermountain West."

\section{Intermountain West Workshop}

"Initial Regional Evaluation of Hazardous Structures in the Intermountain West

June 18 and June 19, 2008

\section{Wednesday, June 18, 2008}

Welcome, Introduction, and Goals

Use of Quaternary Fault Data in the National Seismic Hazard Maps

History and Utility of the Utah

Quaternary Fault Working Group

Hazardous Quaternary Faults in Arizona

Hazardous Quaternary Faults in Colorado

Hazardous Quaternary Faults in New Mexico

Hazardous Quaternary Faults in West Texas and adjacent areas

Discussion: Structures in the Southern IMW

Hazardous Quaternary Faults in Idaho

Hazardous Quaternary Faults in Montana

Hazardous Quaternary Faults in Eastern Oregon

Hazardous Quaternary Faults in Wyoming

Discussion: Structures in the Northern IMW
Anthony Crone (USGS)

Mark Petersen (USGS)

Bill Lund (Utah GS, Cedar City)

Phil Pearthree (AZGS, Tucson)

Vince Matthews (Colo. GS, Denver)

David Love

(NM Bur. Geol. \& Min. Res.)

Michael Machette (USGS)

Anthony Crone, lead

Bill Phillips (Idaho GS)

Mike Stickney

(Mont. Bur. Mines \& Geol.)

Ian Madin (DOGAMI)

Ken Pierce (USGS) and

Jim McCalpin (GeoHaz. Inc.)

Kathy Haller, (USGS), lead

\section{Thursday, June 19, 2008}

Need for criteria to rank structures

A. Crone and K. Haller (USGS)

Group discussion: Developing priorities for future studies

Final Recommendations and Closing Comments

Adjourn 
Appendix 3. Selected PowerPoint presentations from the IMW workshop

Appendix 3a. Utah Quaternary Fault Parameters Working Group, William R. Lund, Utah Geological Survey
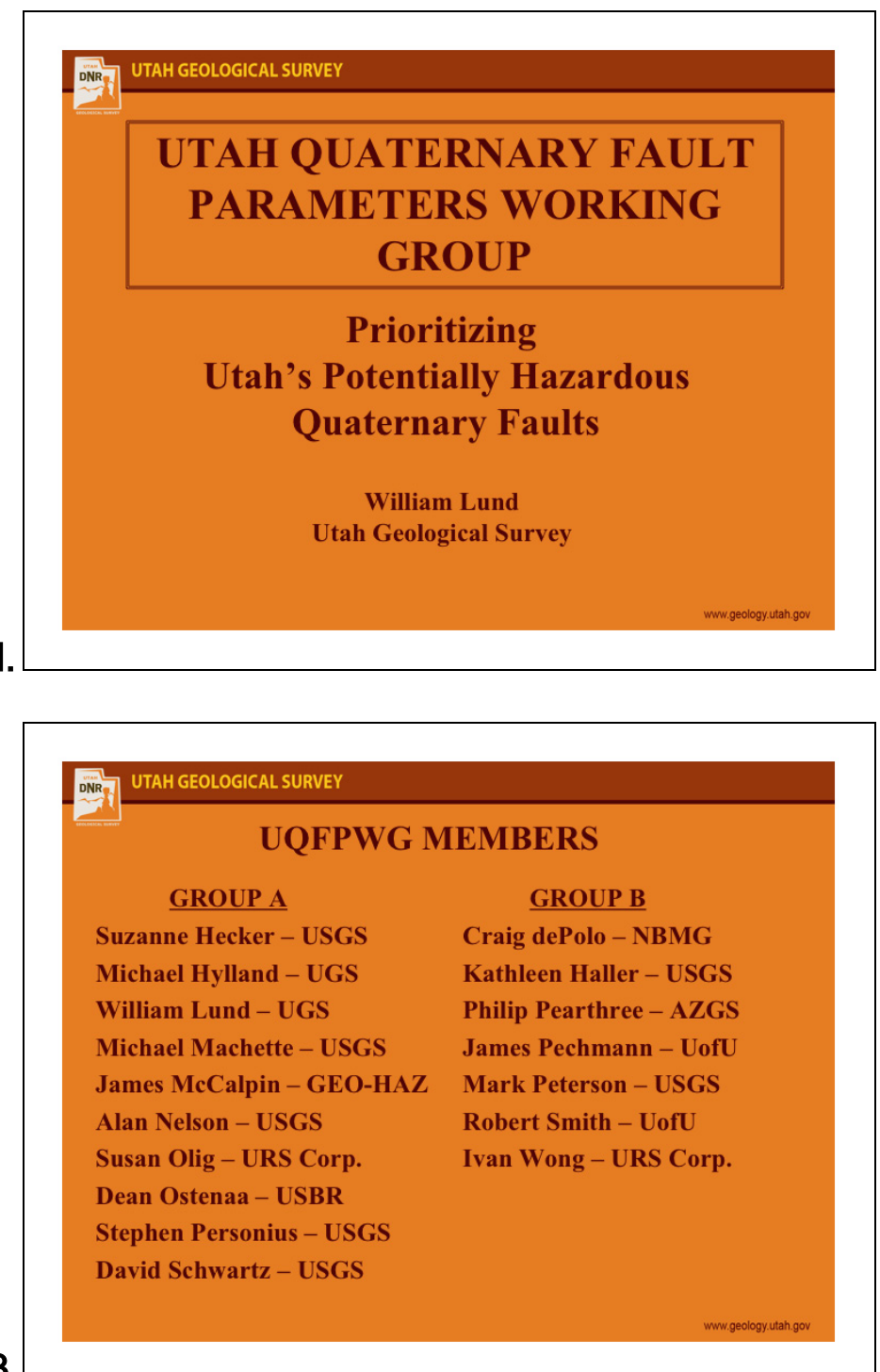

2
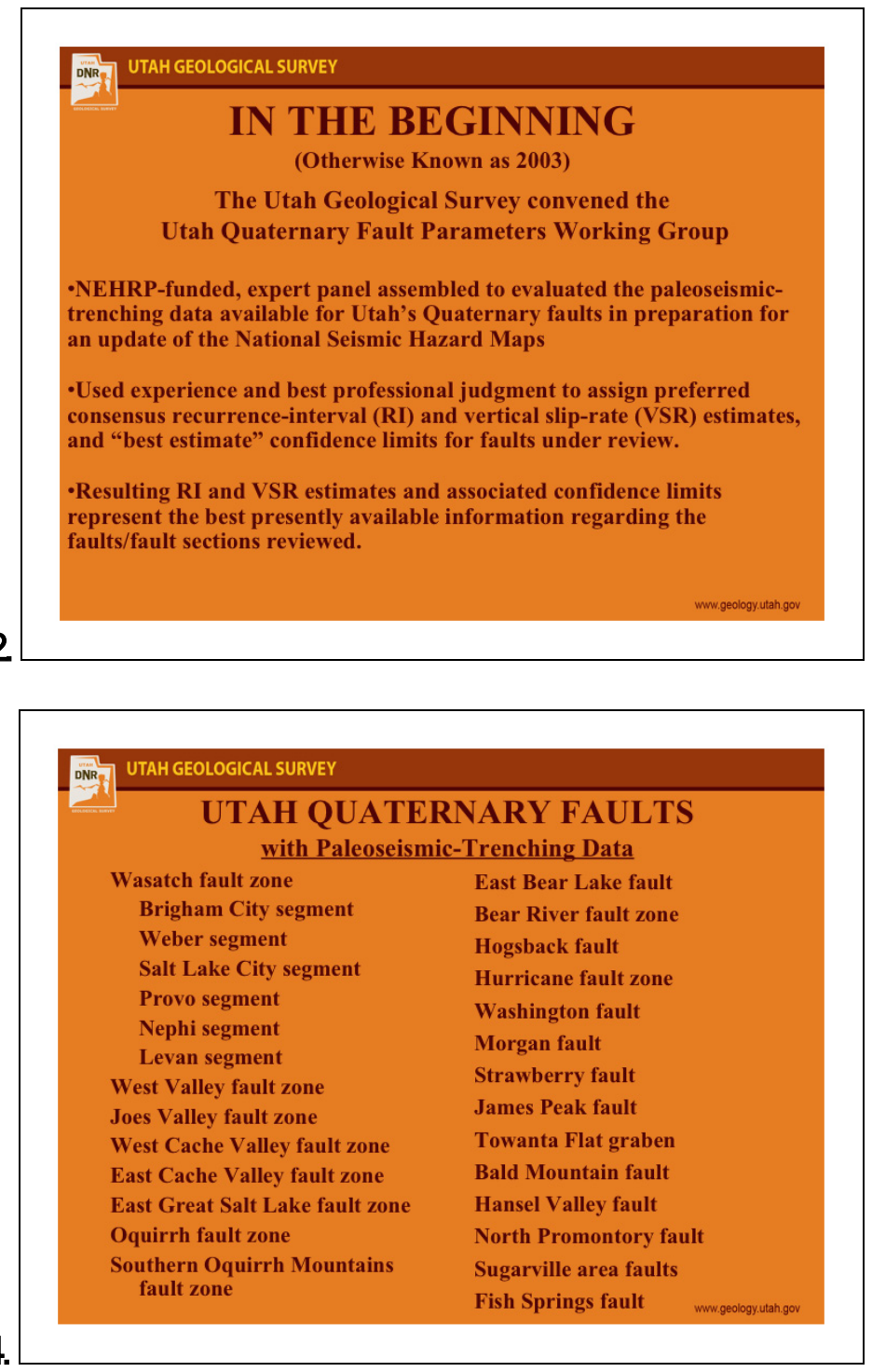


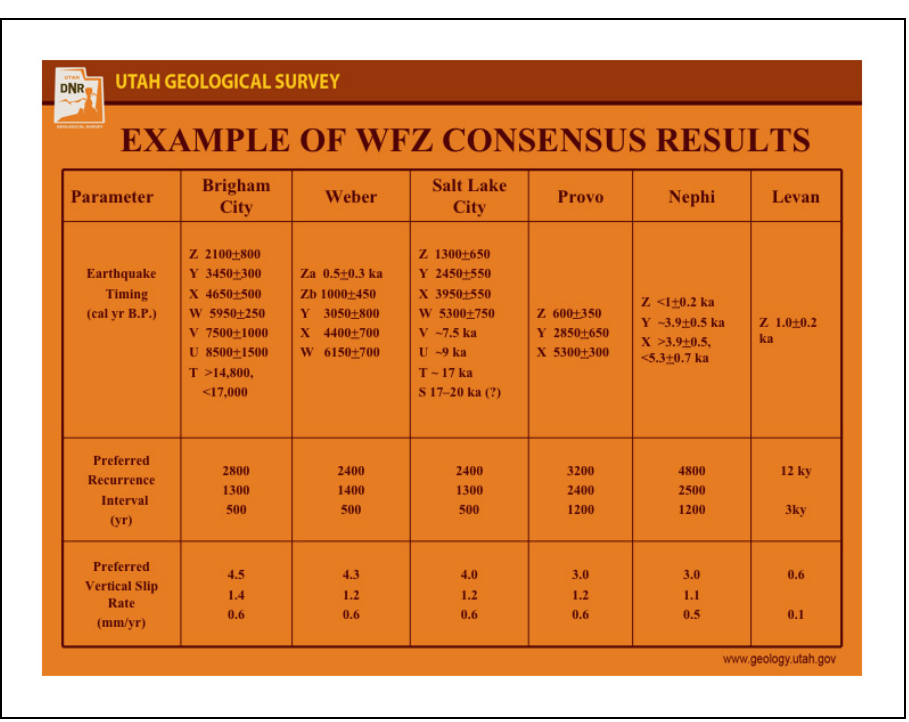

N

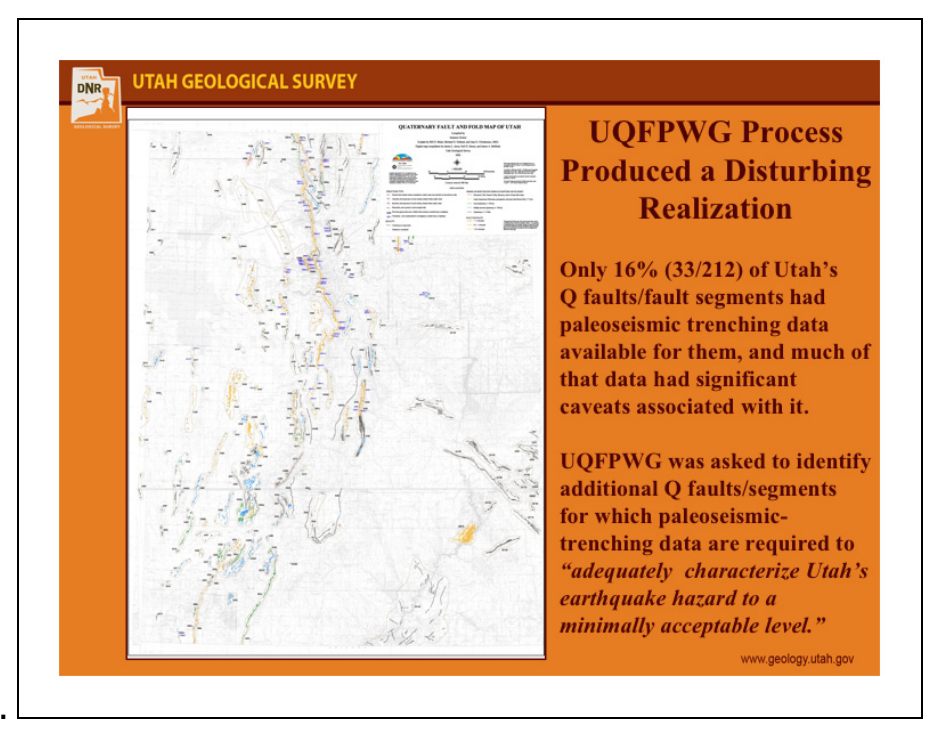

6.

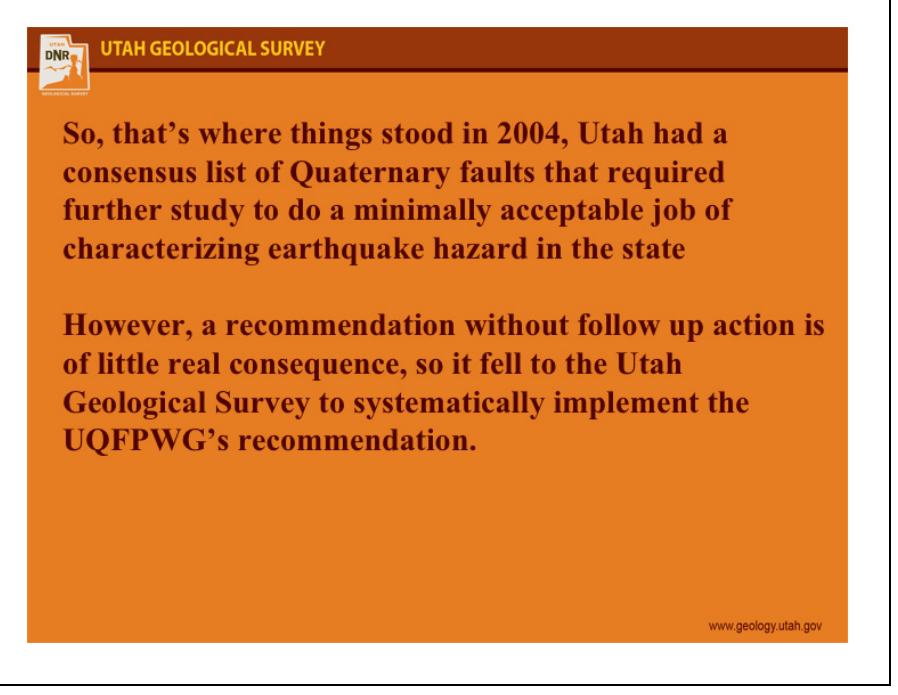

8.
7. 


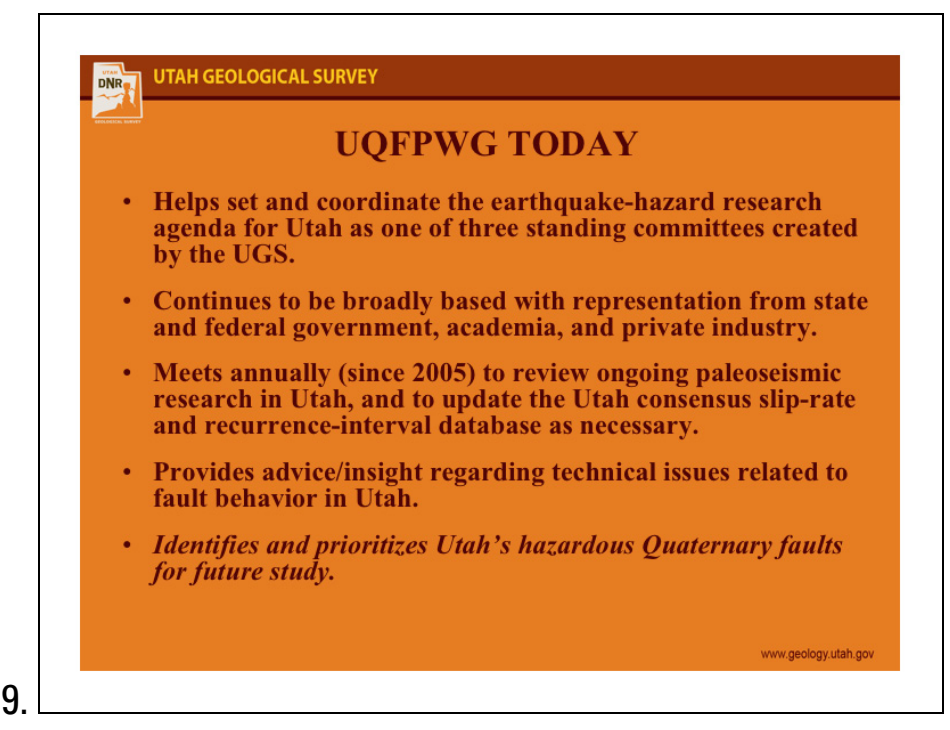

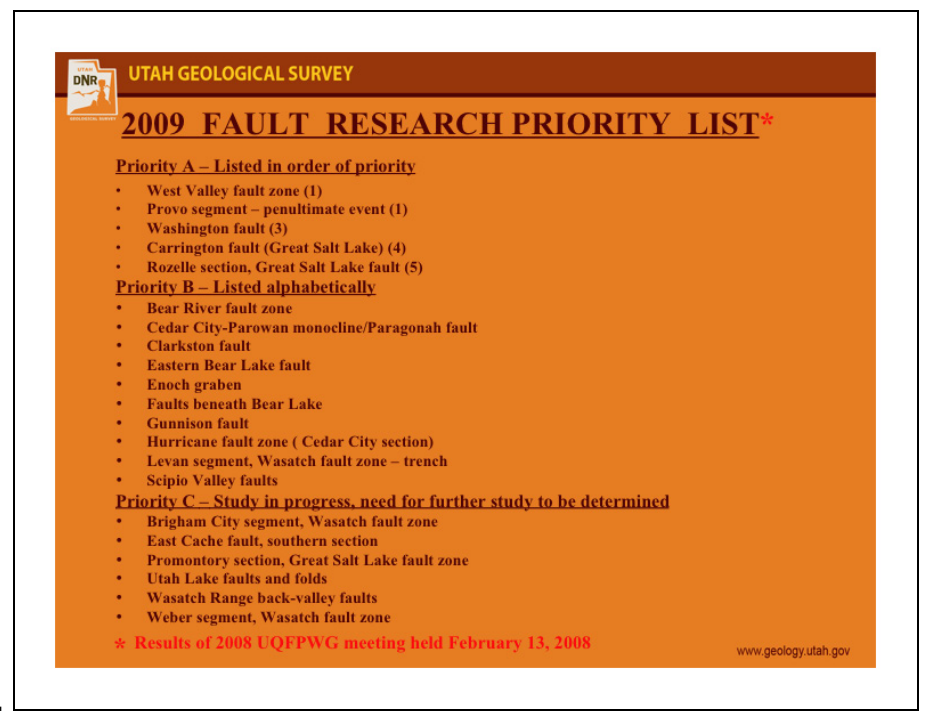

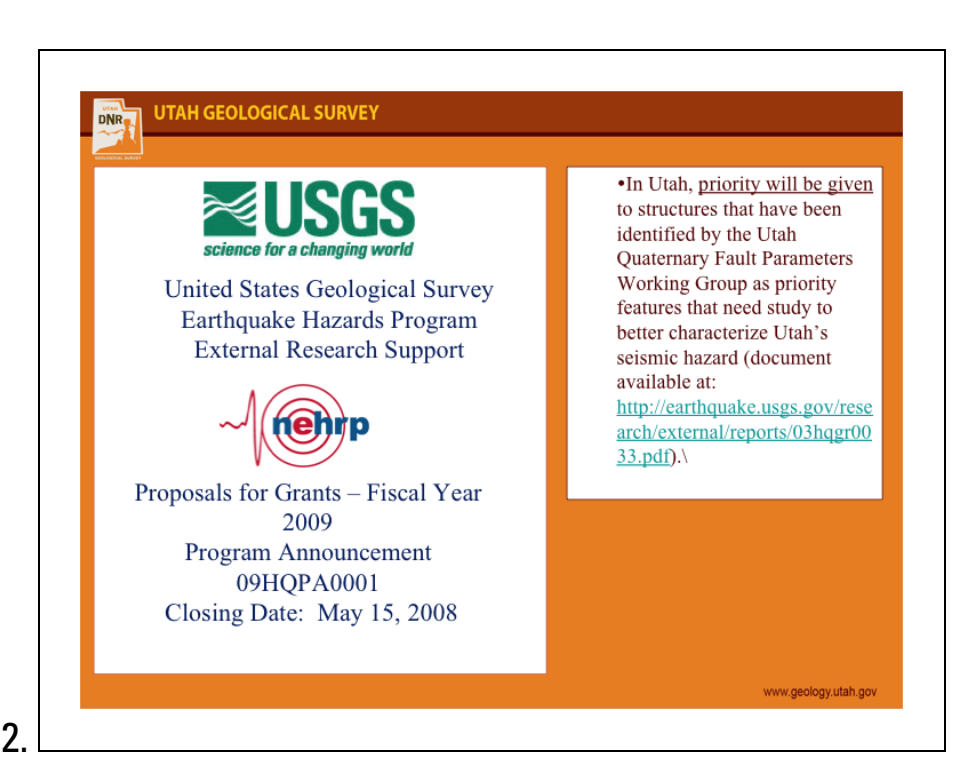




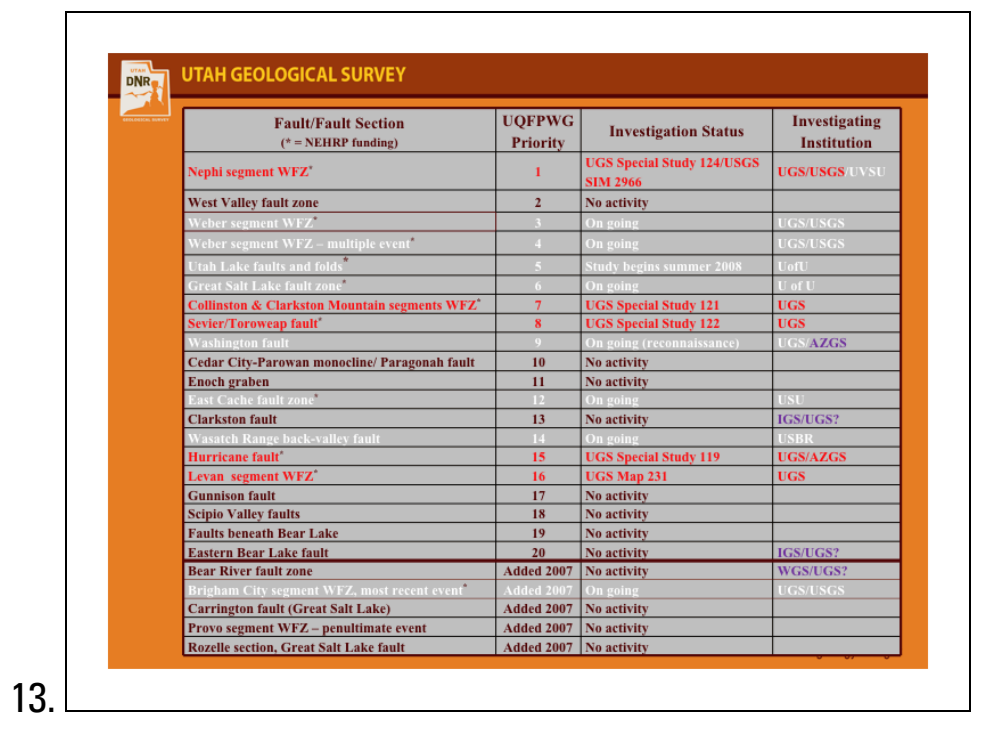


Appendix 3b. Particularly Hazardous Quaternary Faults in Arizona, Phillip A. Pearthree, Arizona Geological Survey
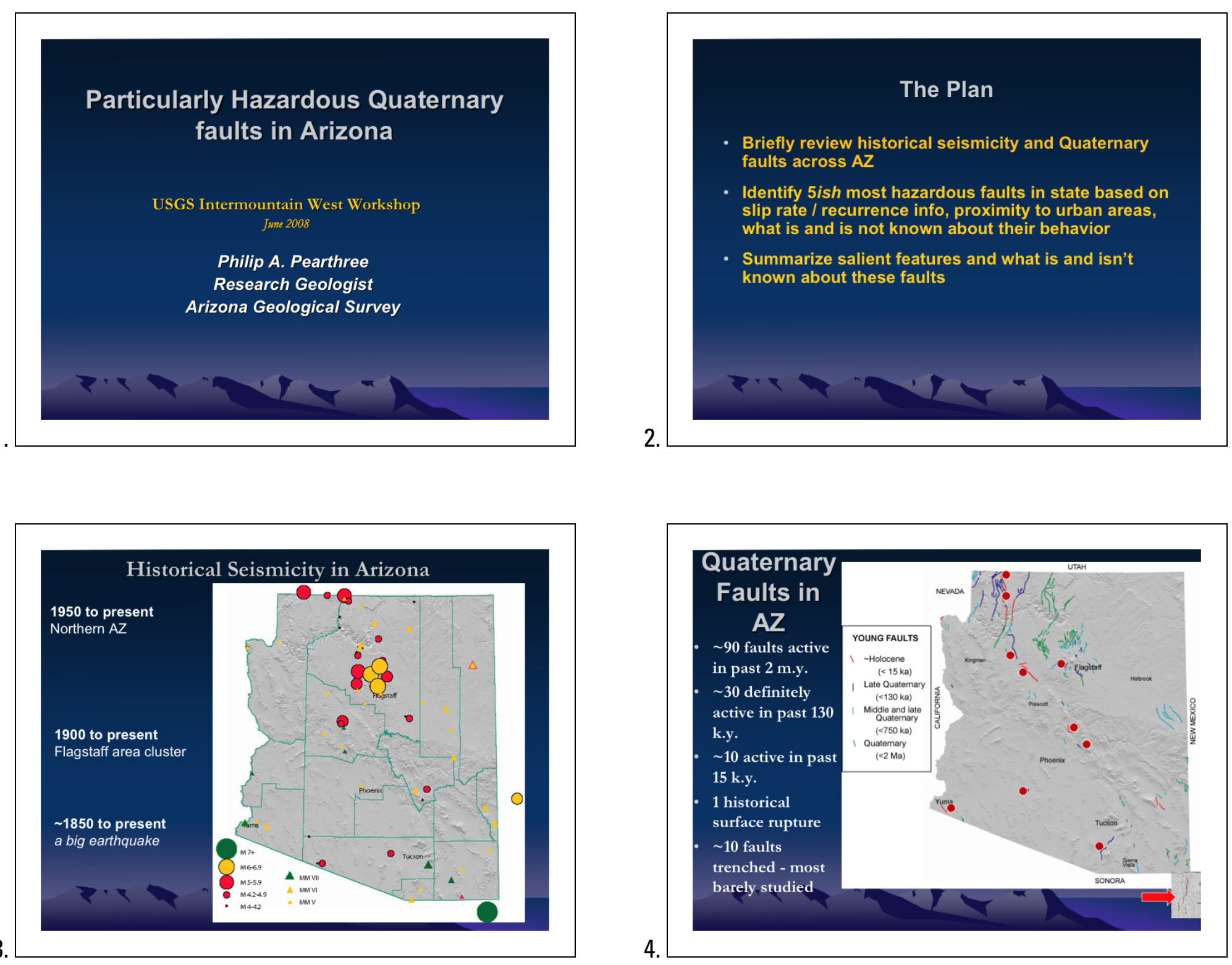

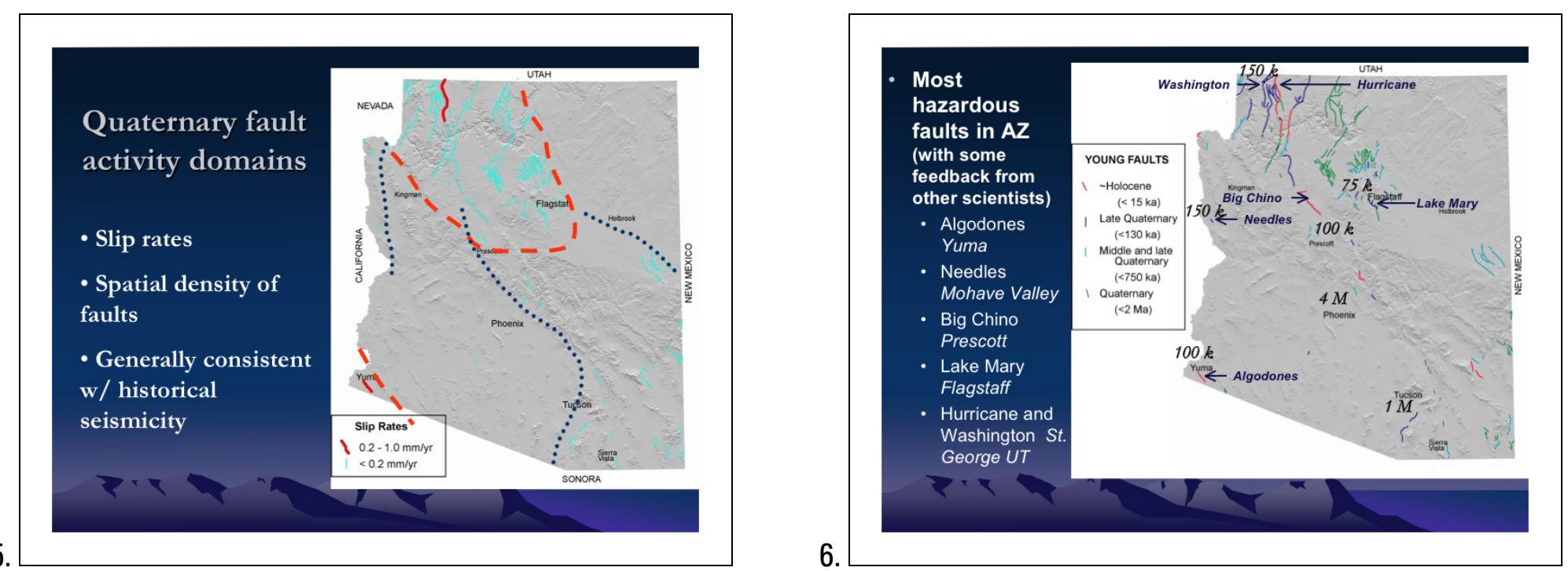

o
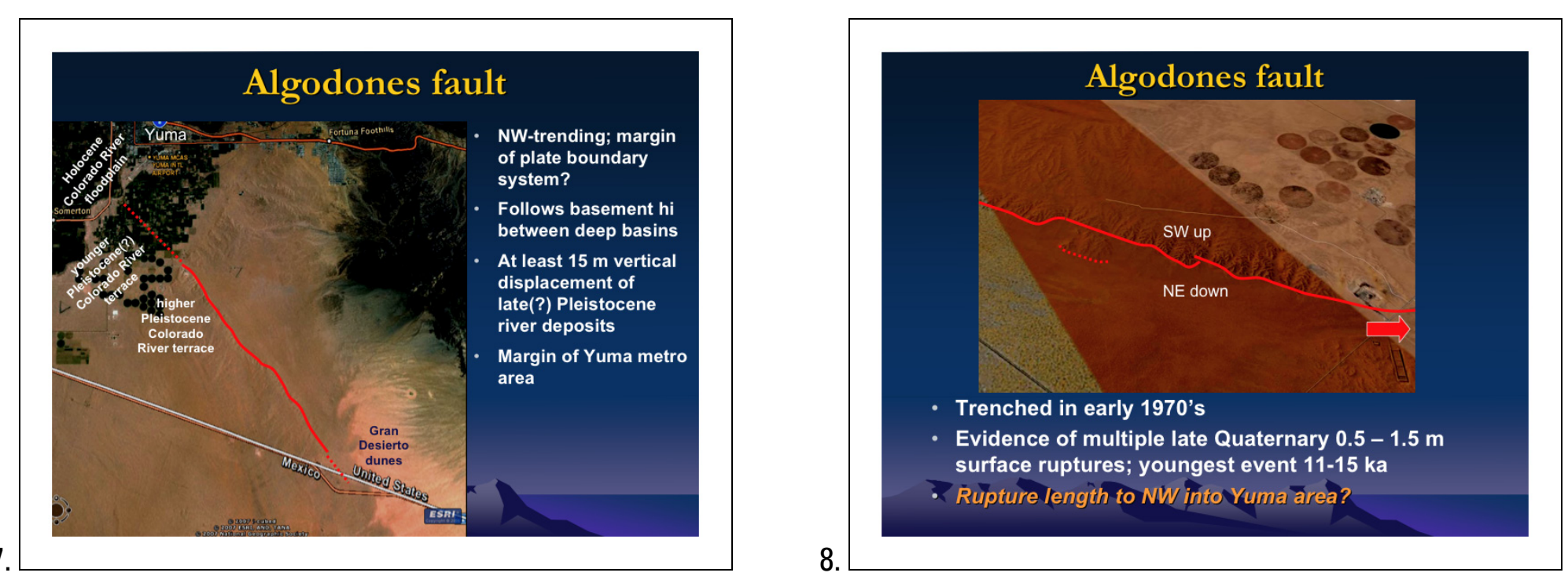


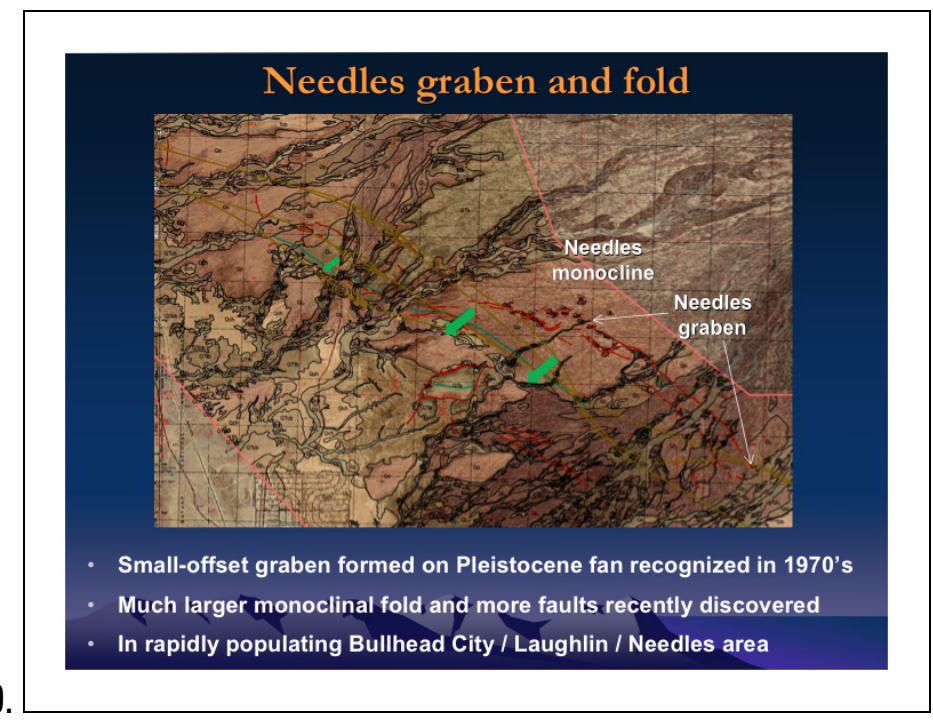

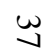

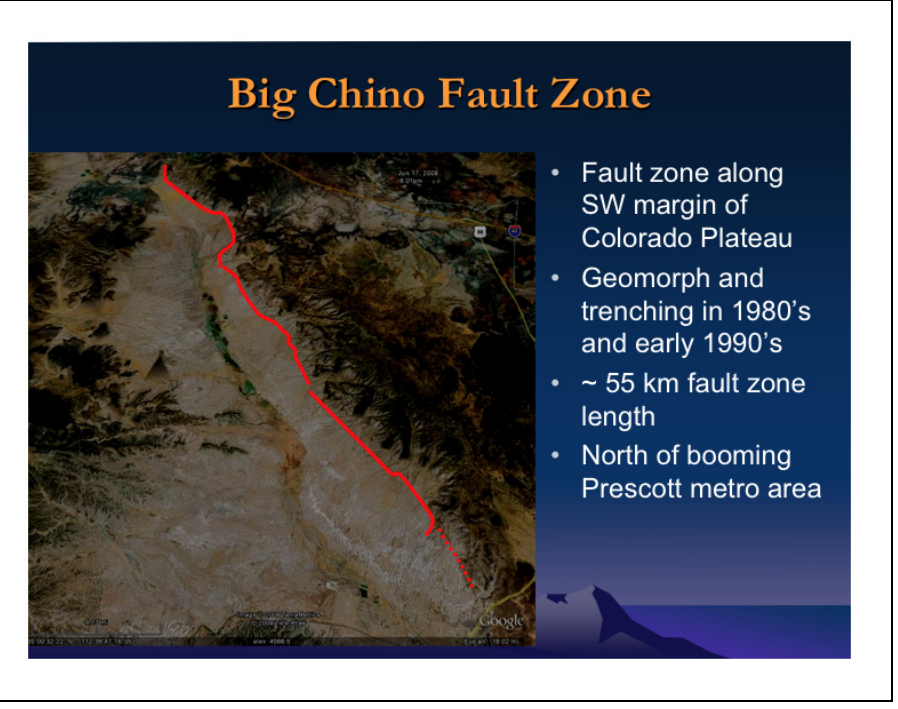

11.

\section{Needles graben and fold}

- Graben is wrinkle on

back of larger fold

. $>25 \mathrm{~m}$ vertical

displacement of $\sim$ middle

Pleistocene alluvial fan

- Substantially greater

tilting of Pliocene river

deposits

- More faulting than

previously recognized

- Total zone length at

least $20 \mathrm{~km}$

- ADOT interest, but

how to study?

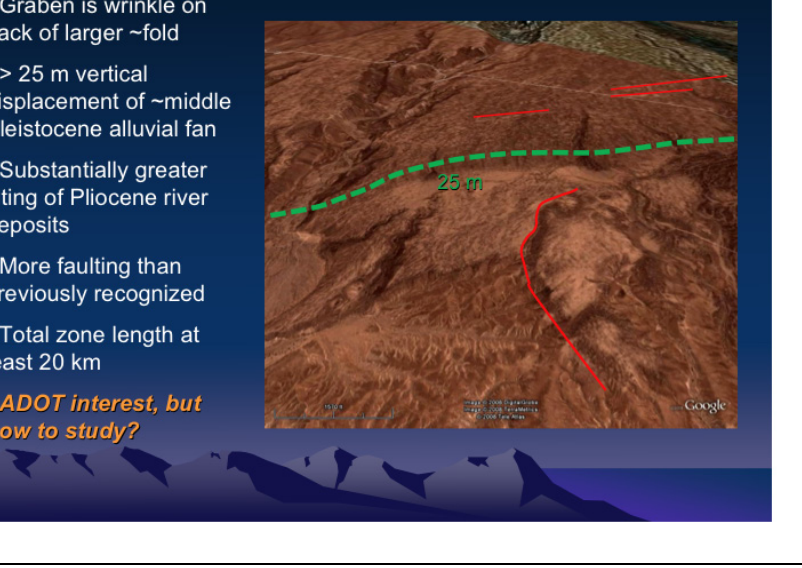

10.

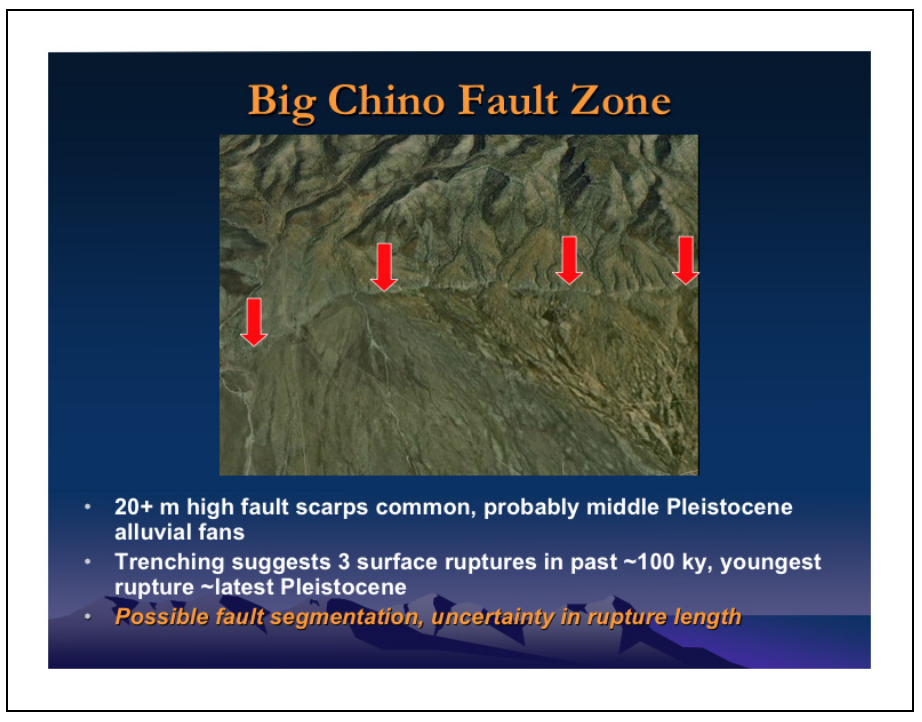



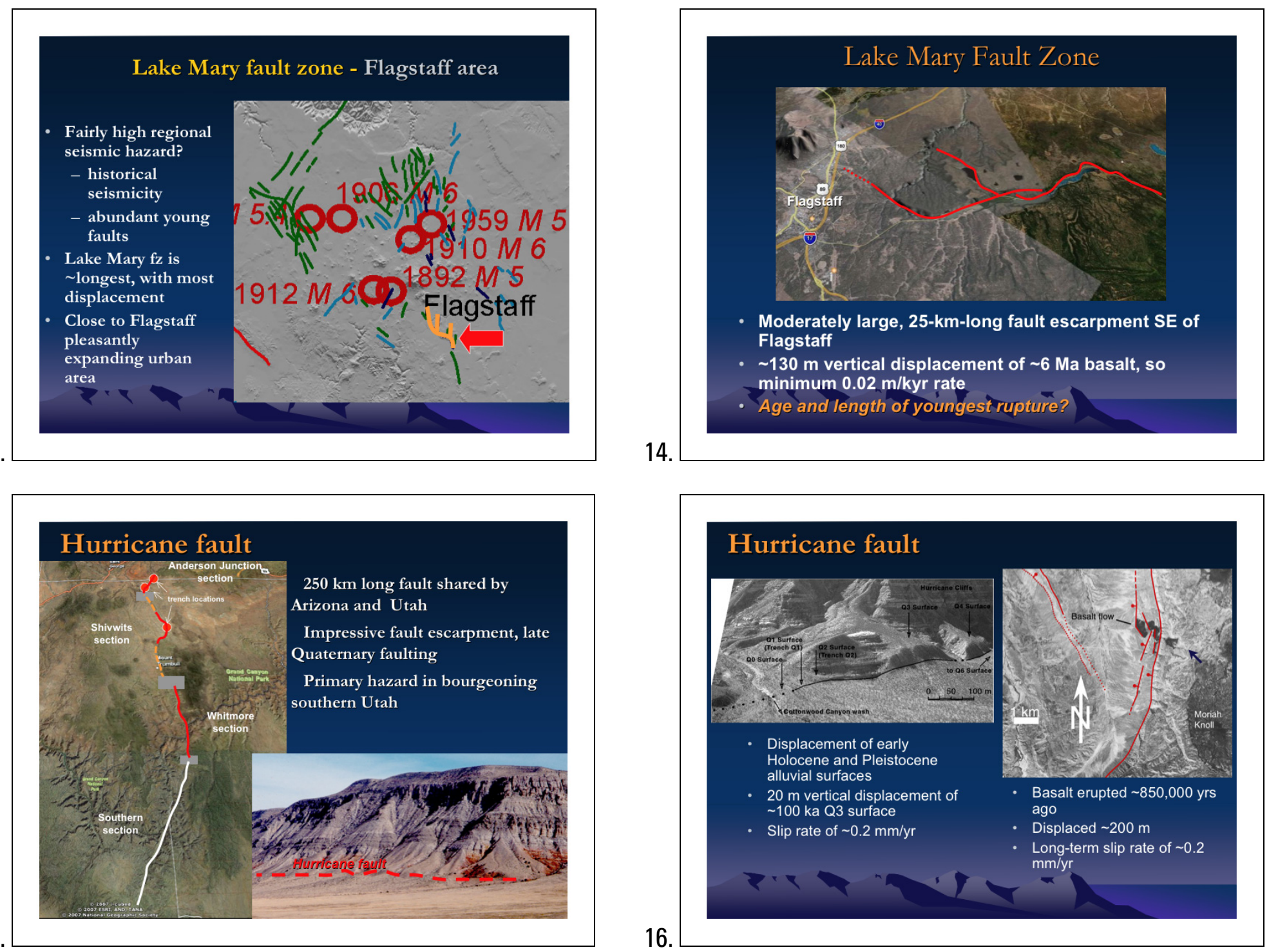


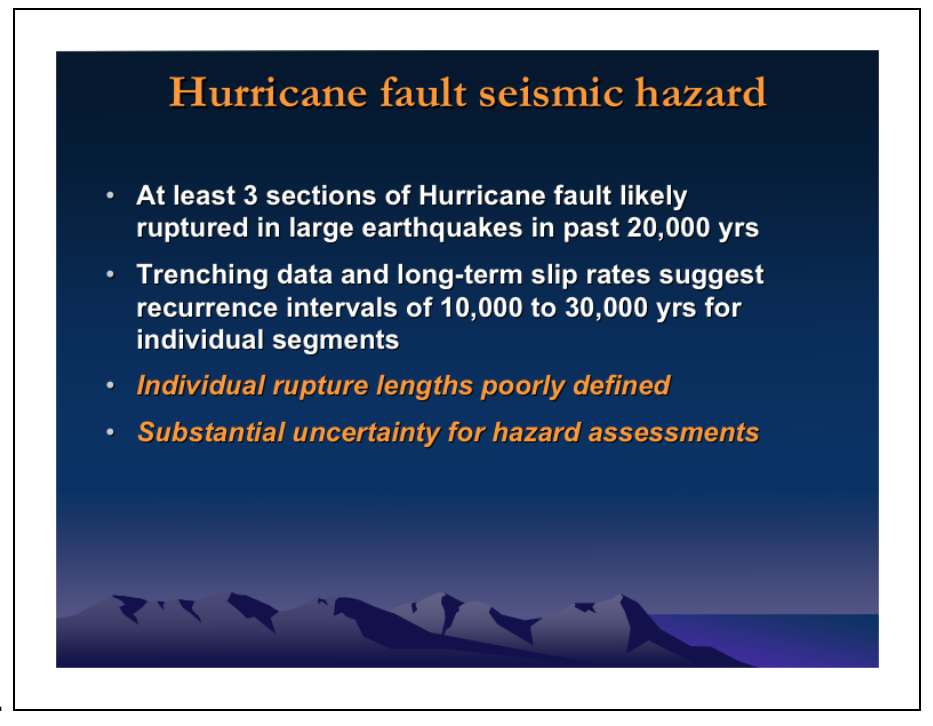

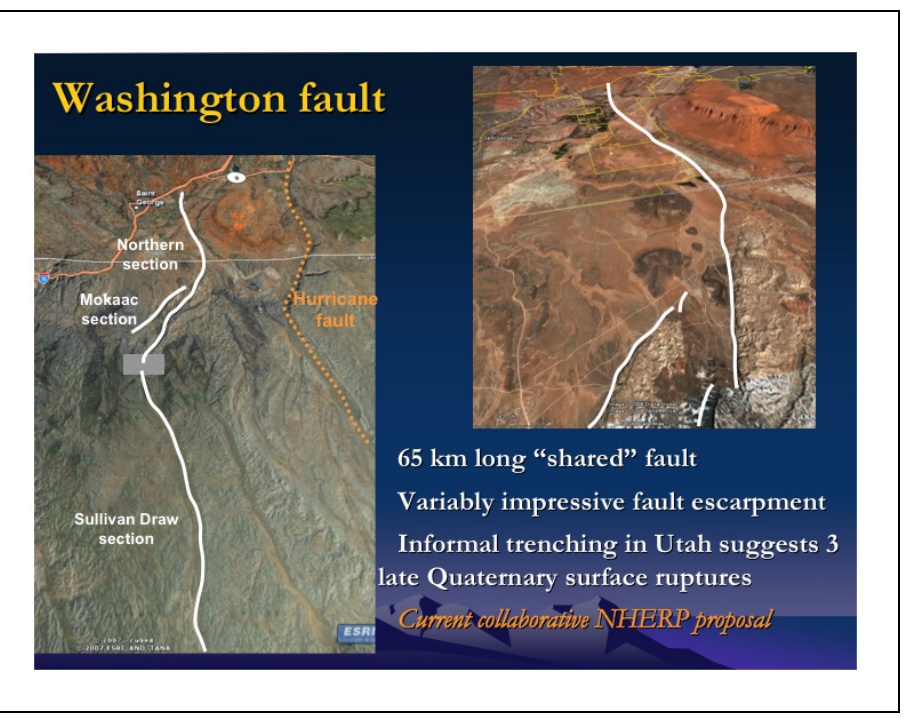

18.

19. 
Appendix 3c. Hazardous Quaternary faults in Colorado, Vincent Matthews, State Geologist, Colorado Geological Survey
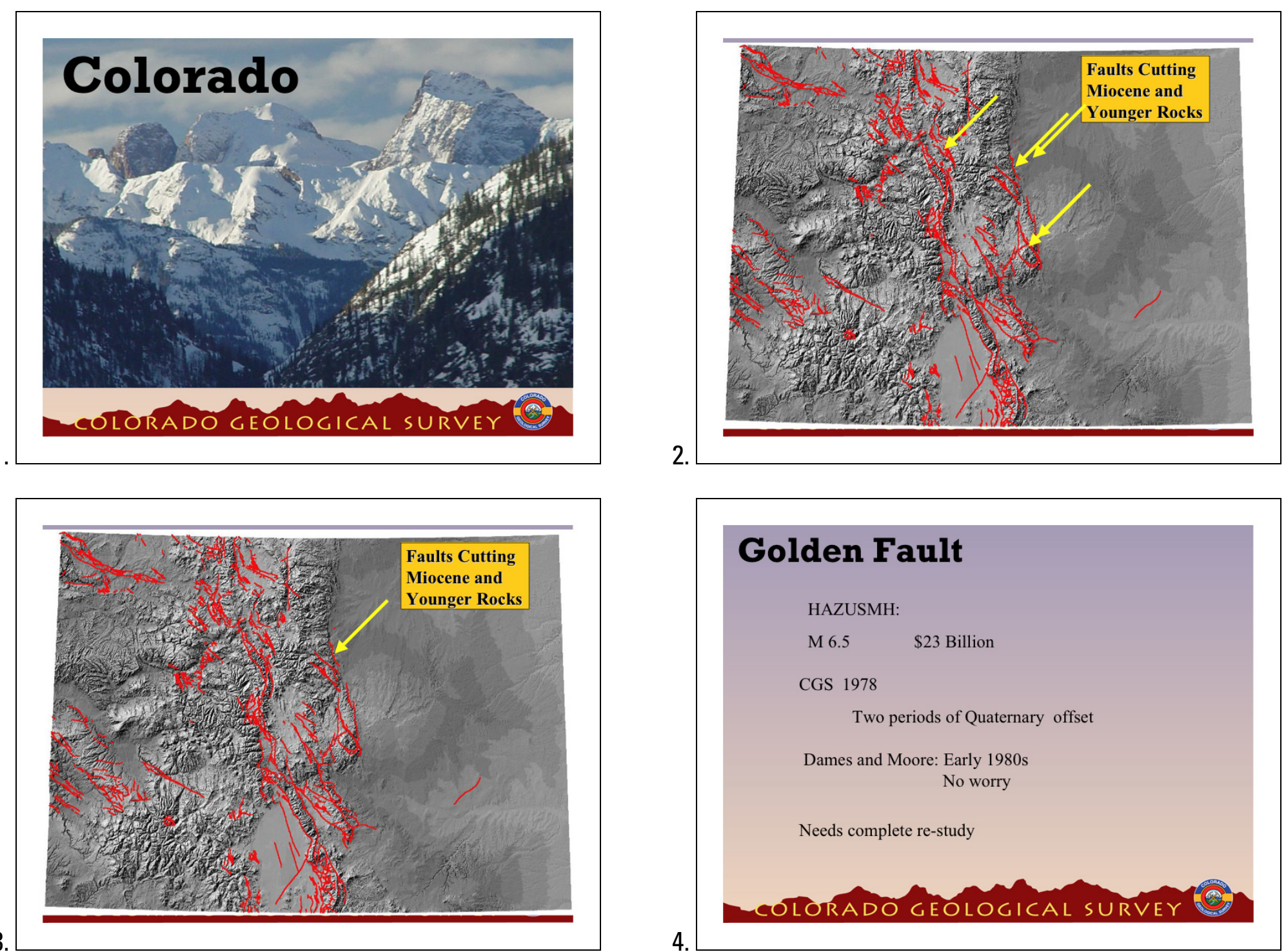


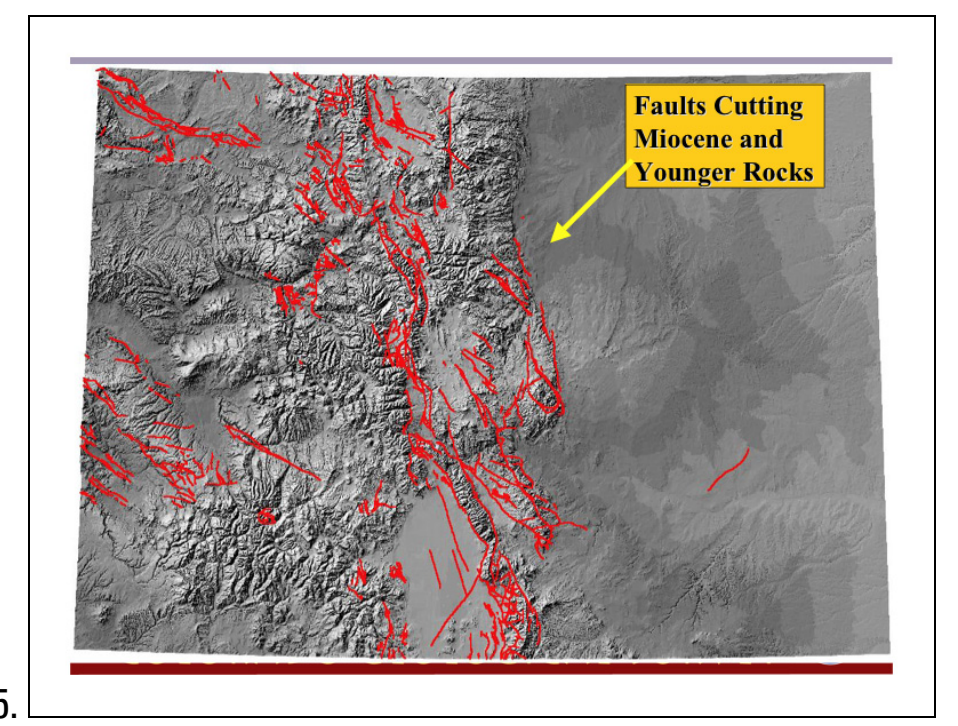

$\pm$

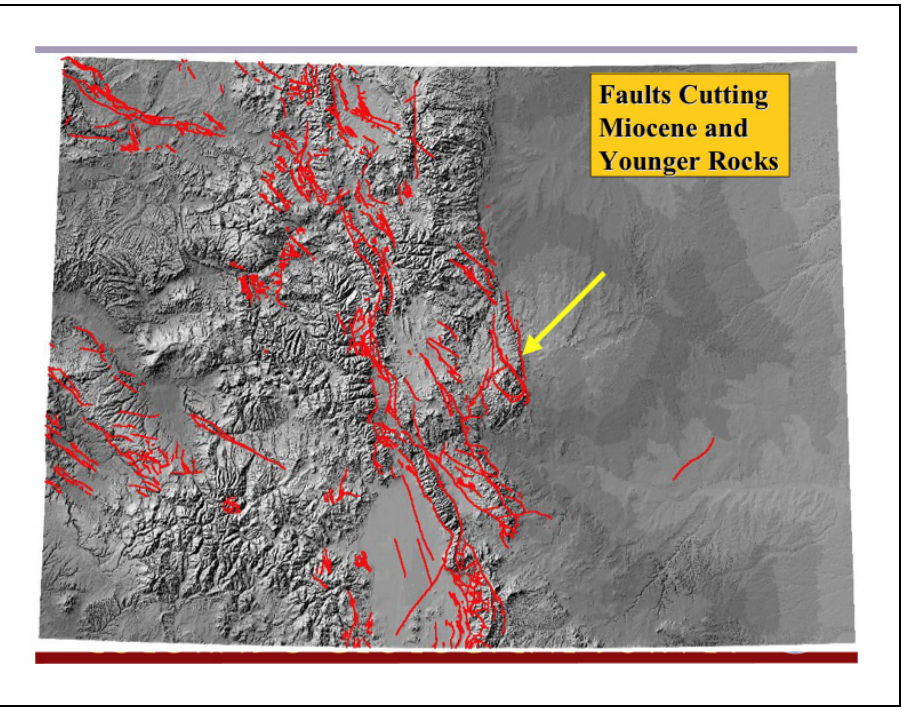

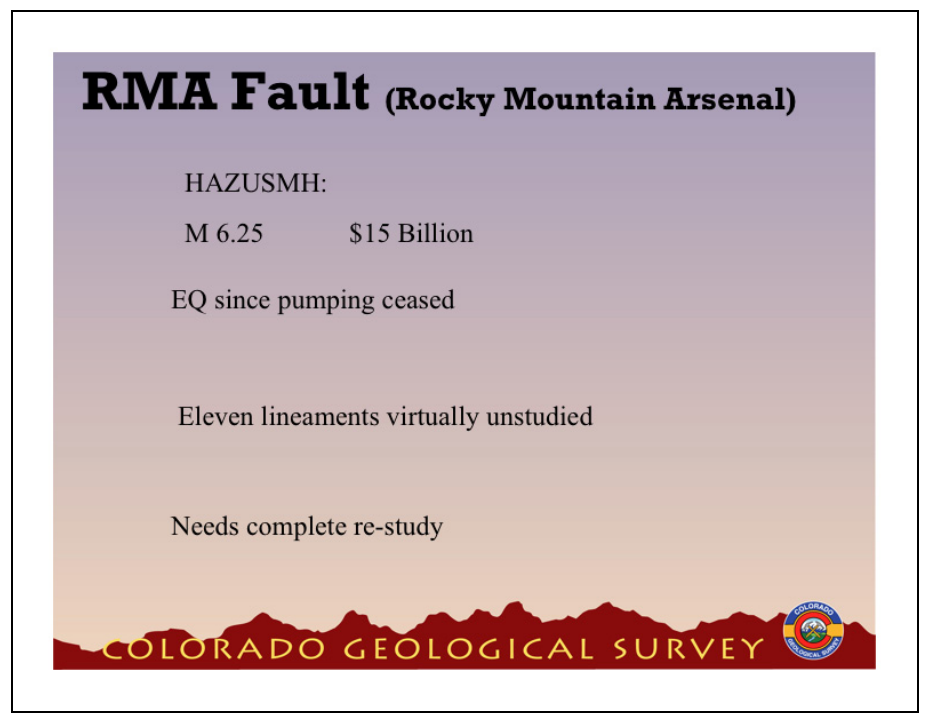

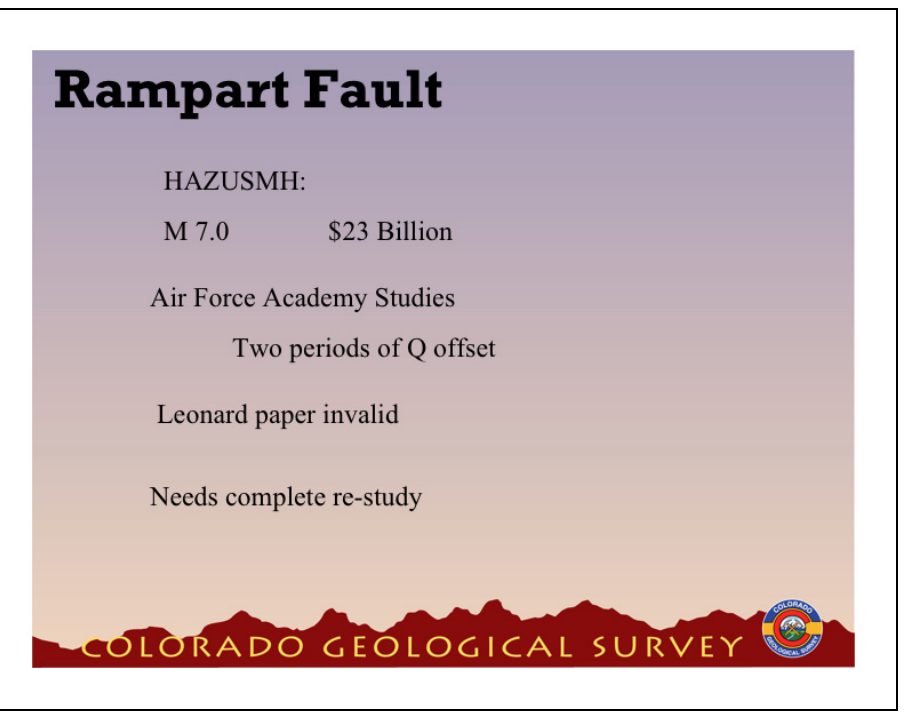




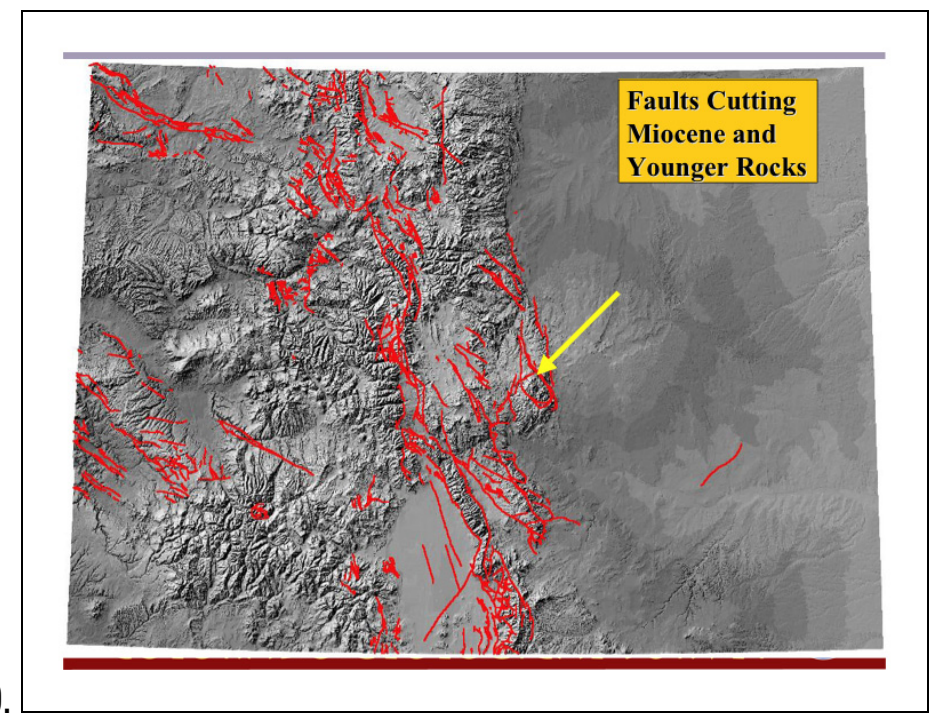

N

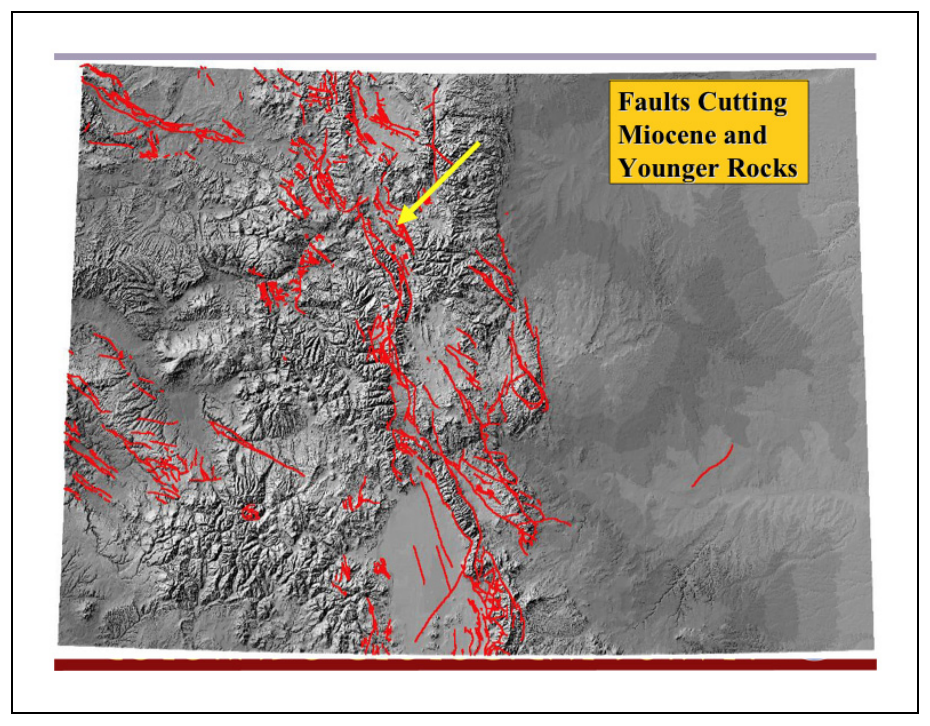

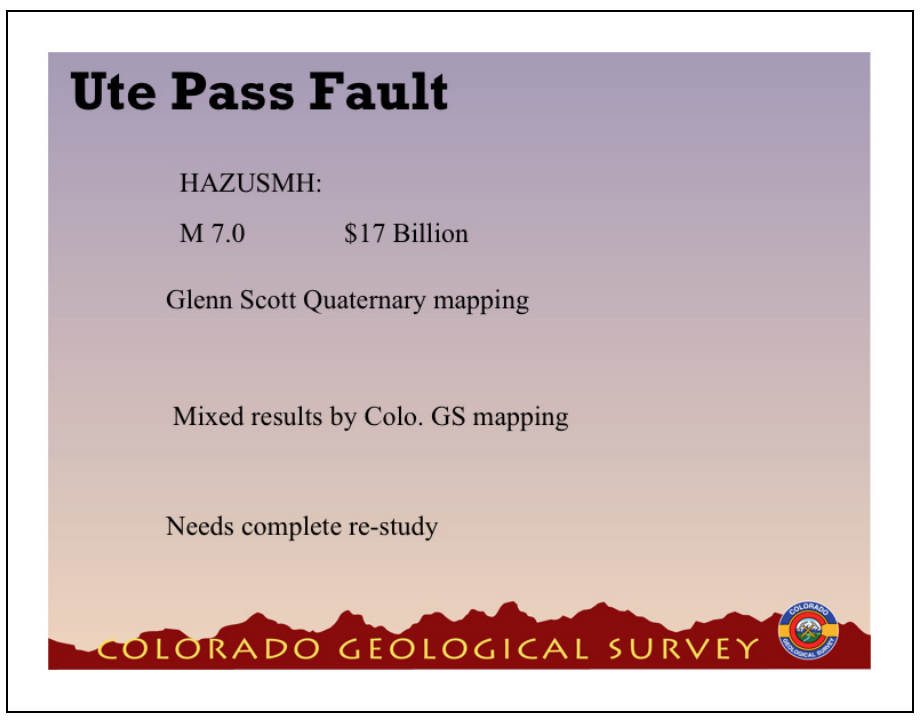

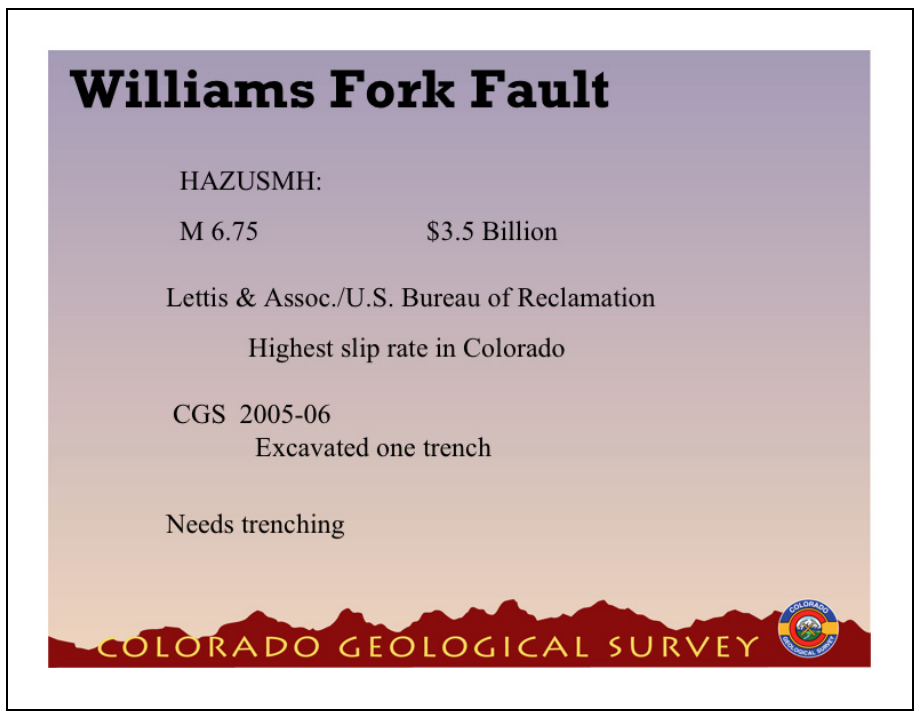



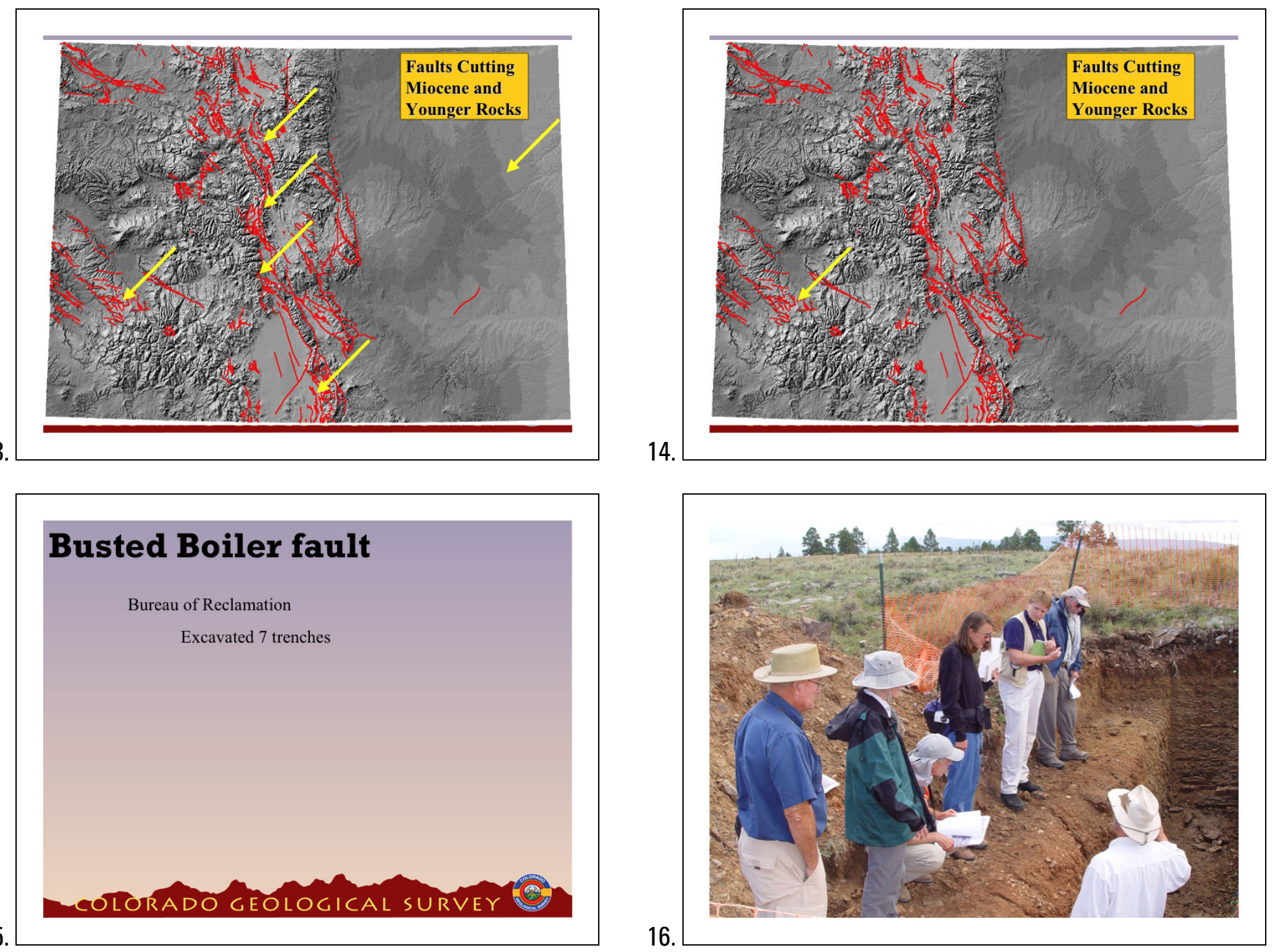

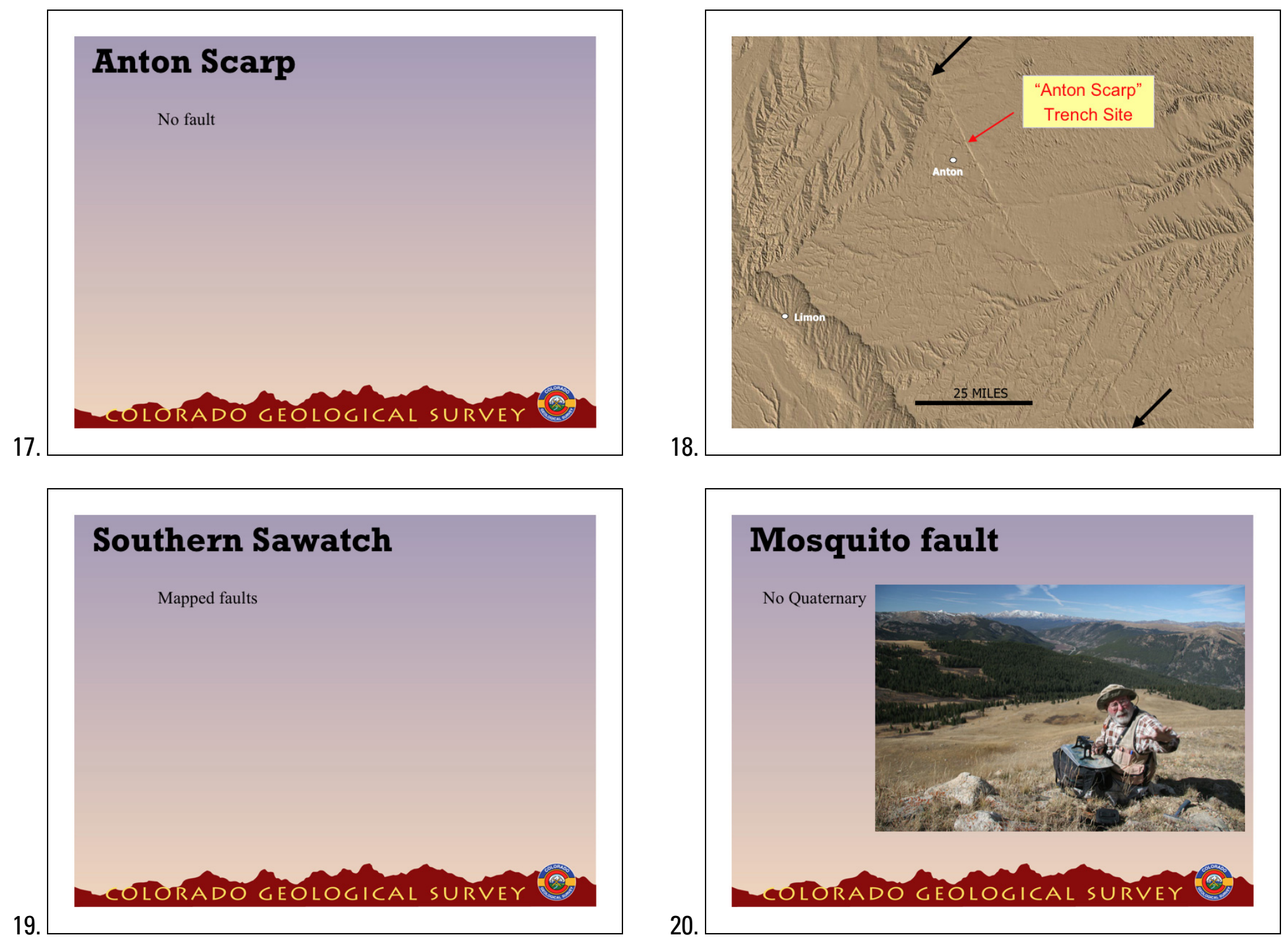


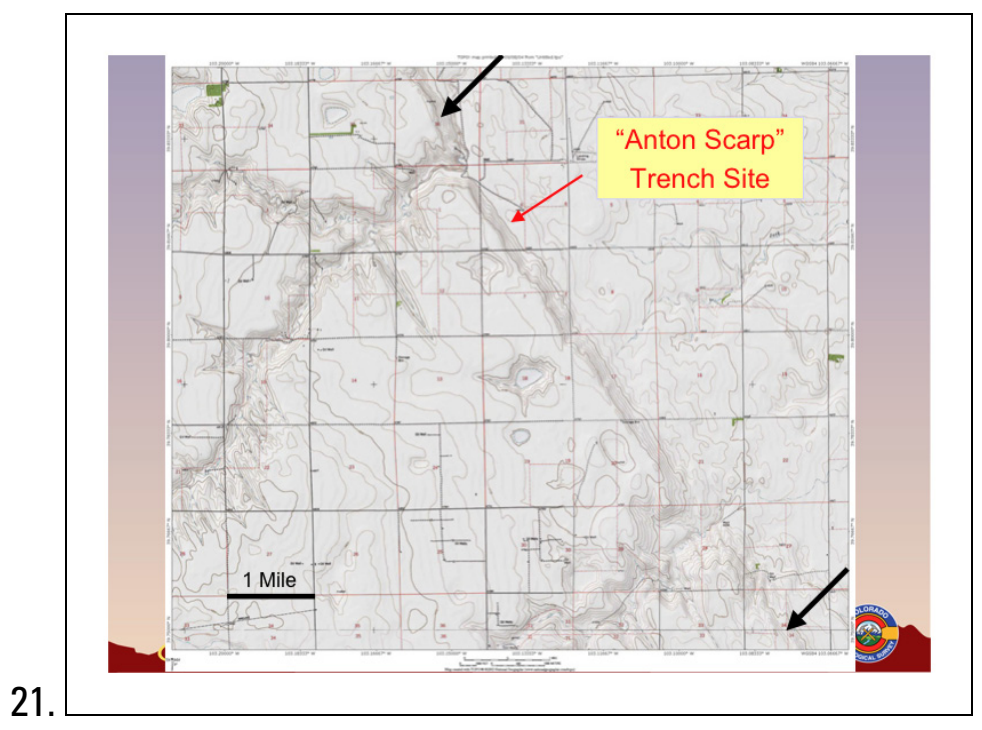

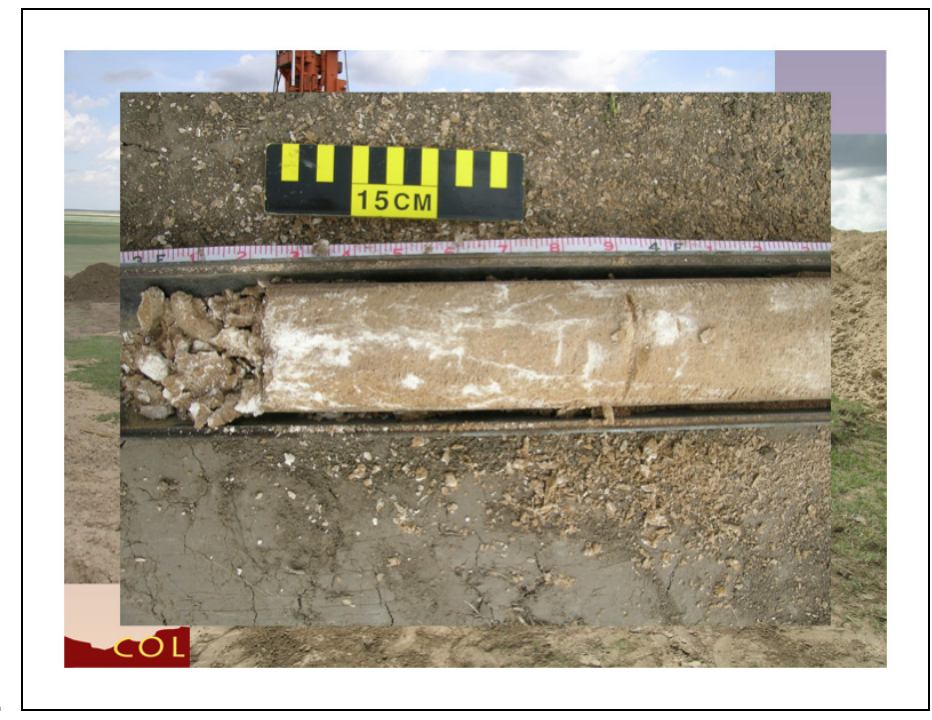

22.
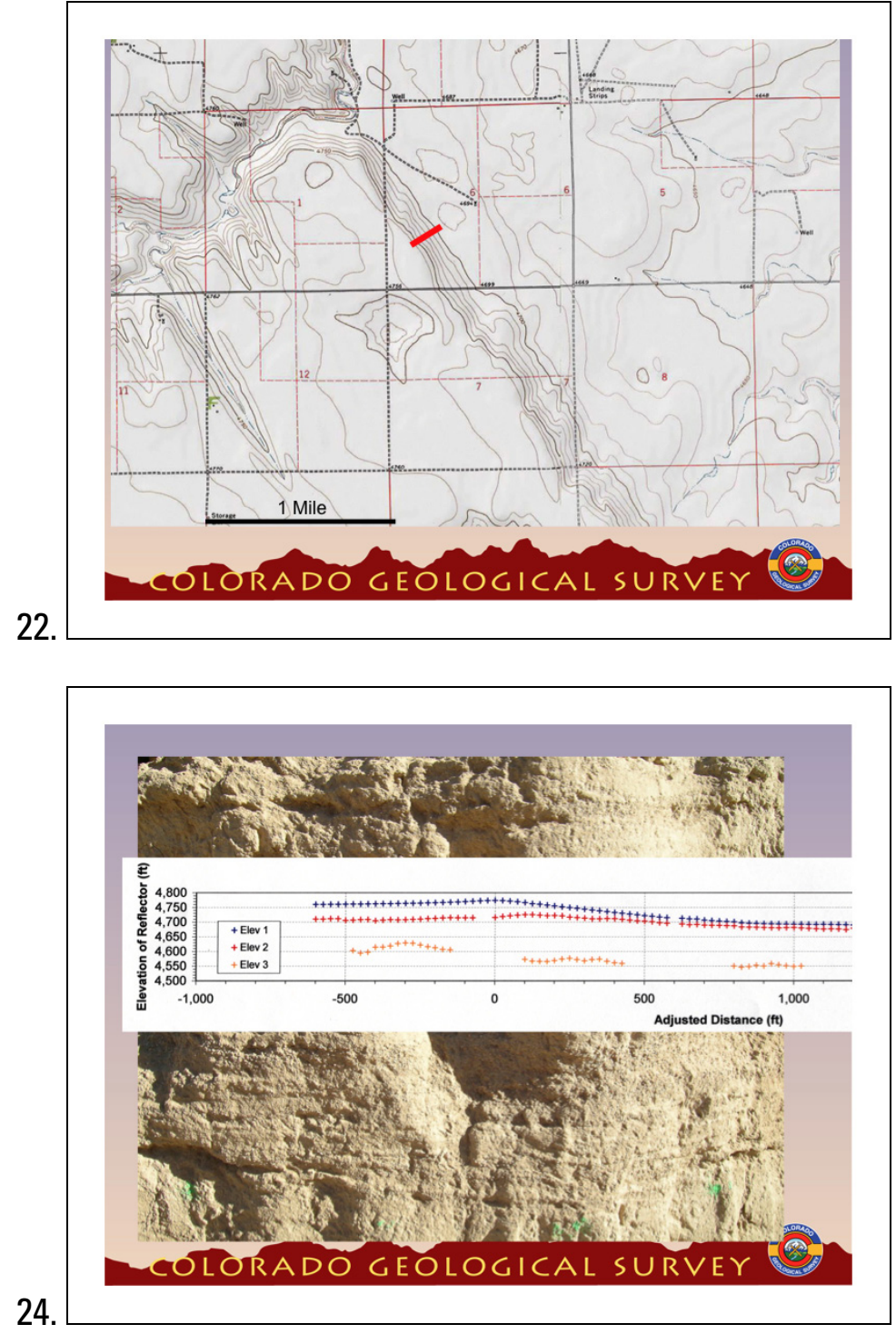

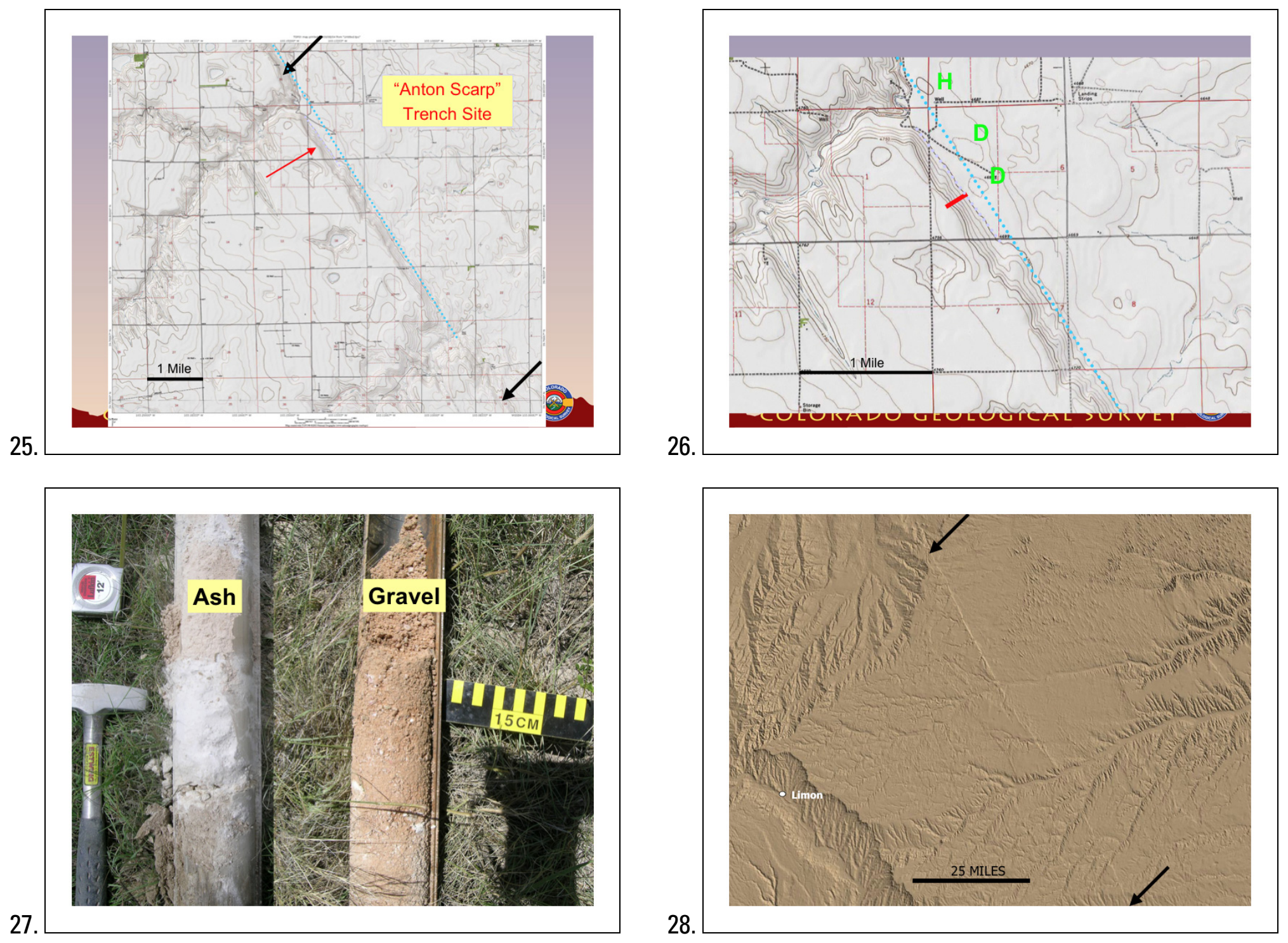

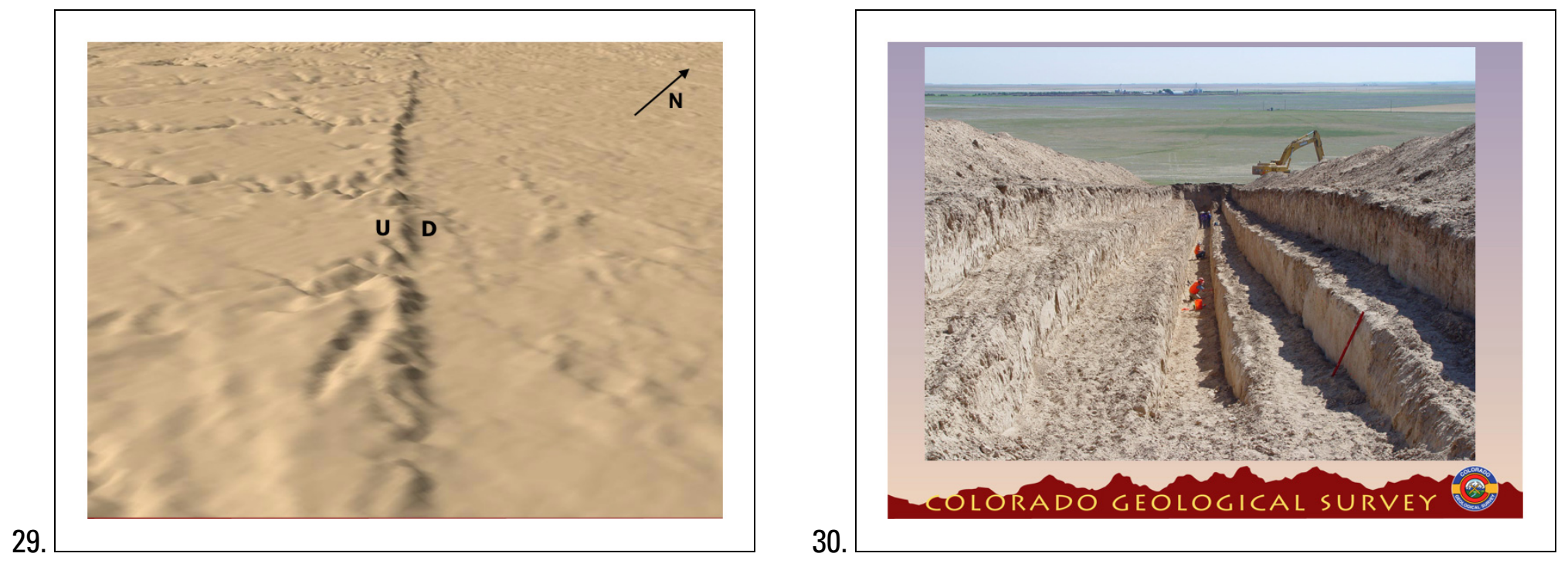

$\pm$

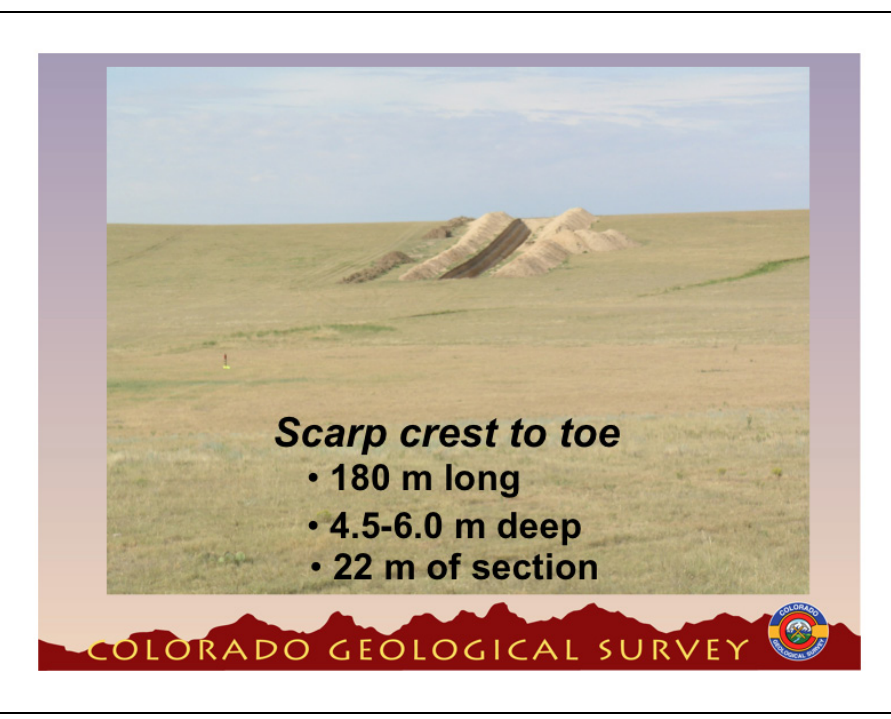


Appendix 3d. Hazardous Quaternary Faults in Idaho, Bill Phillips and Roy Breckenridge, Idaho Geological Survey
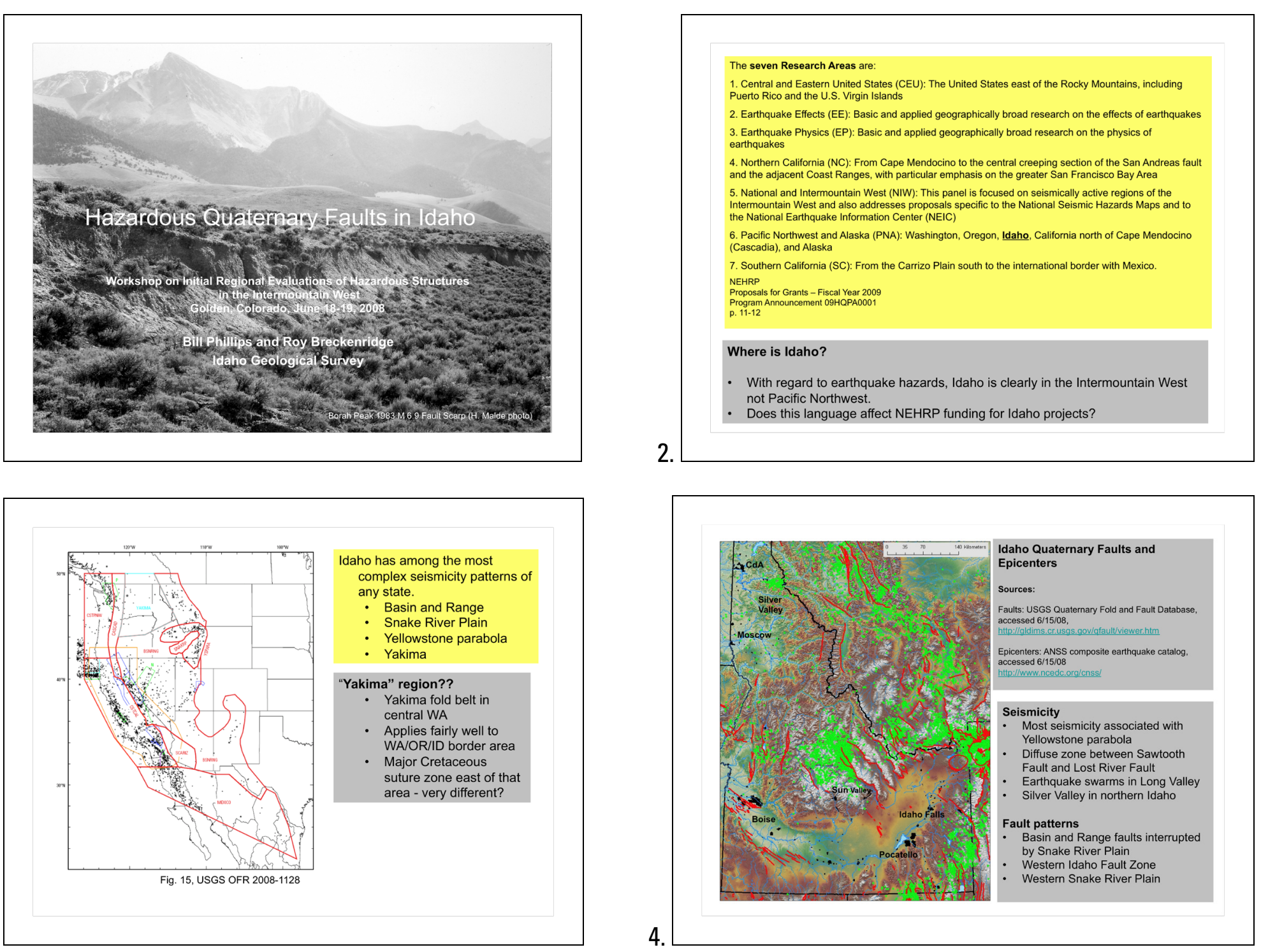


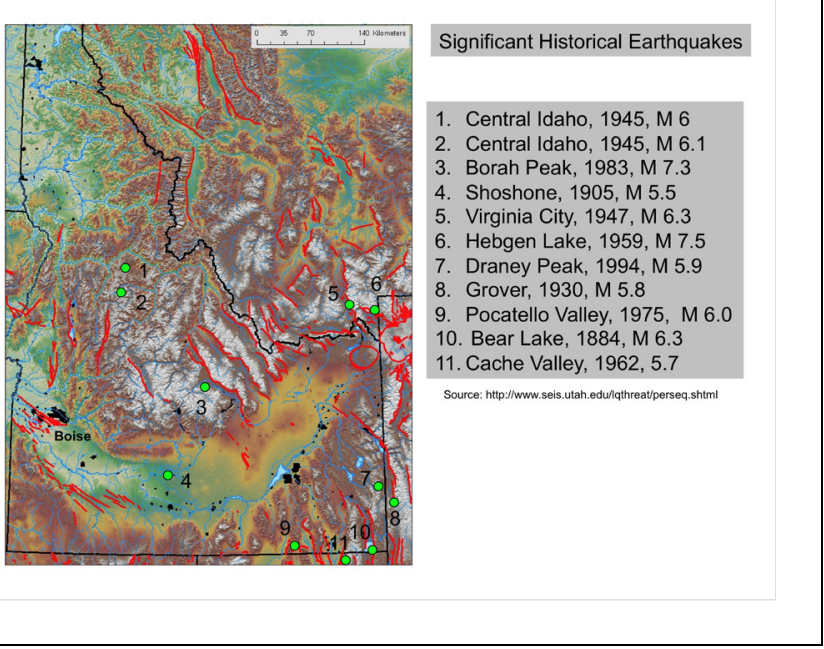

$\frac{6}{6}$

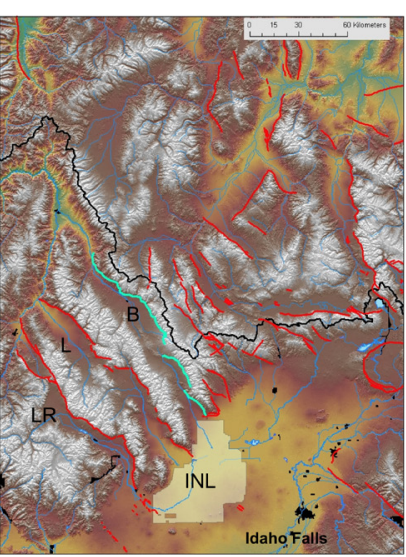

Major Faults of Idaho

Yellowstone parabola

Beaverhead

Used in 2008 NSHM

Length: $134 \mathrm{~km}$
Sense: Normal

Dip: SW

Slip Rate: $0.12 \mathrm{~mm} / \mathrm{y}$

6 segments

no trenches
no numerical dating

all

Why we picked it: "Most poorly studie

Why we picked it: "Most poofly
major fault in the state"

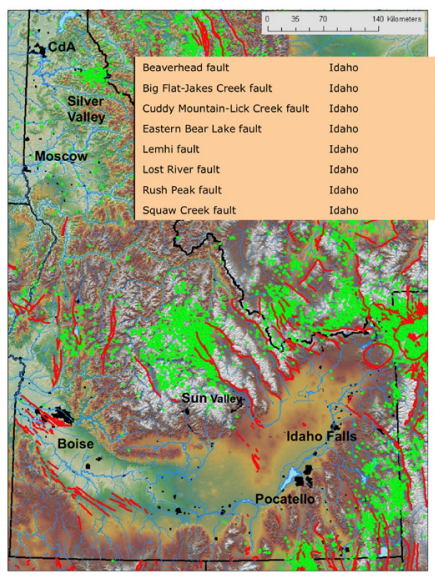

2008 National Seismic Hazard Map

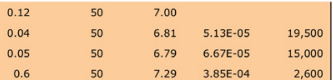

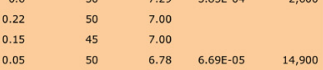

\begin{tabular}{|rrrr|}
\hline 50 & 6.78 & $6.698-05$ & 14,900 \\
50 & 7.03 & $9.435-05$ & 10,600 \\
\hline & & & \\
\hline
\end{tabular}

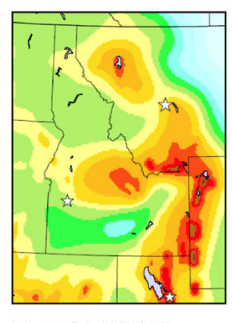

-hertz SA 10\% / 50 years

6.

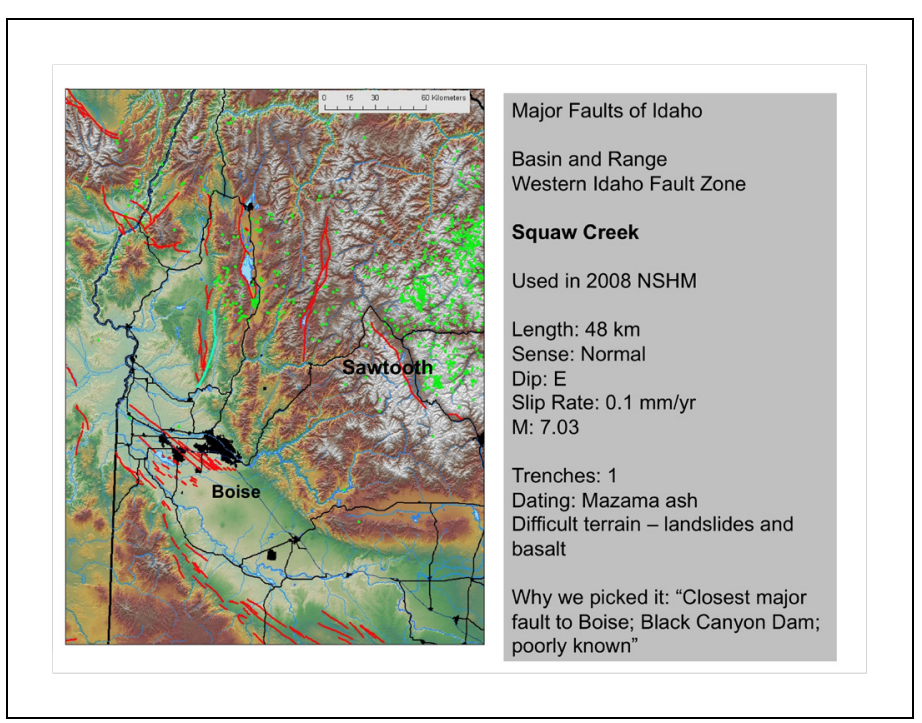



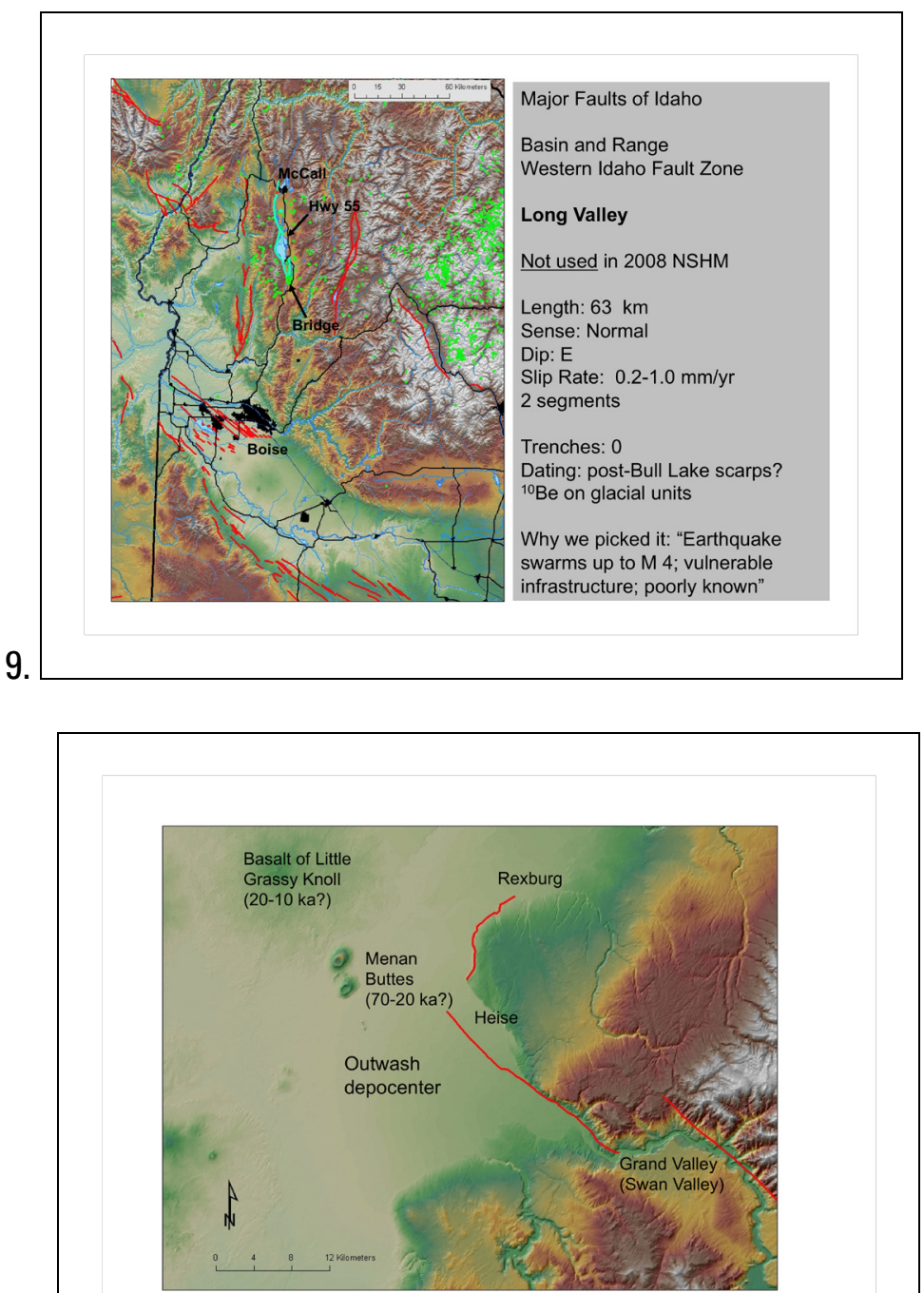

11.

Control by Heise-Grand Valley fault on volcanism and basin geometry?
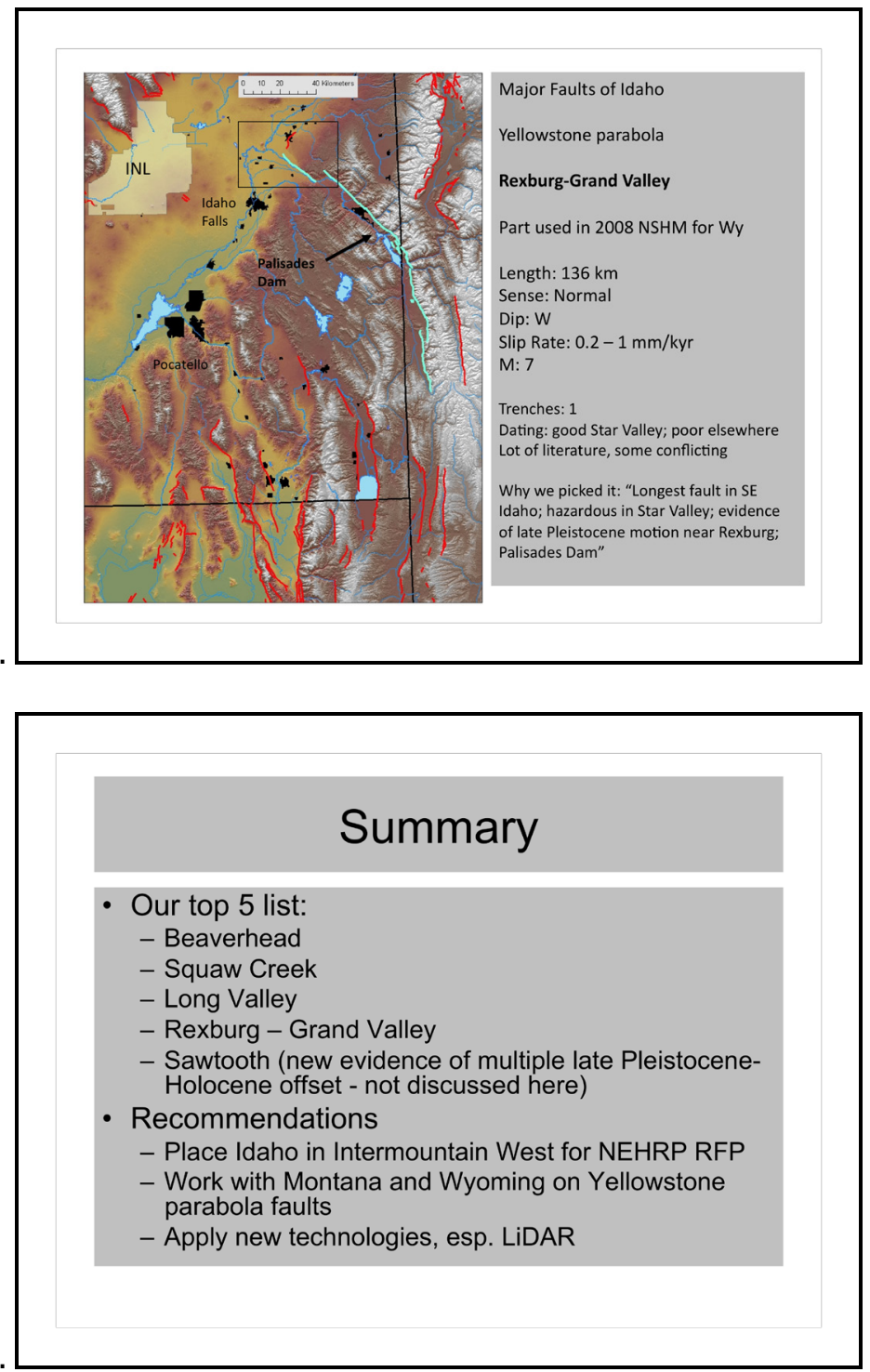
Appendix 3e. Hazardous Quaternary Faults in Montana, Michael Stickney, Montana Bureau of Mines and Geology

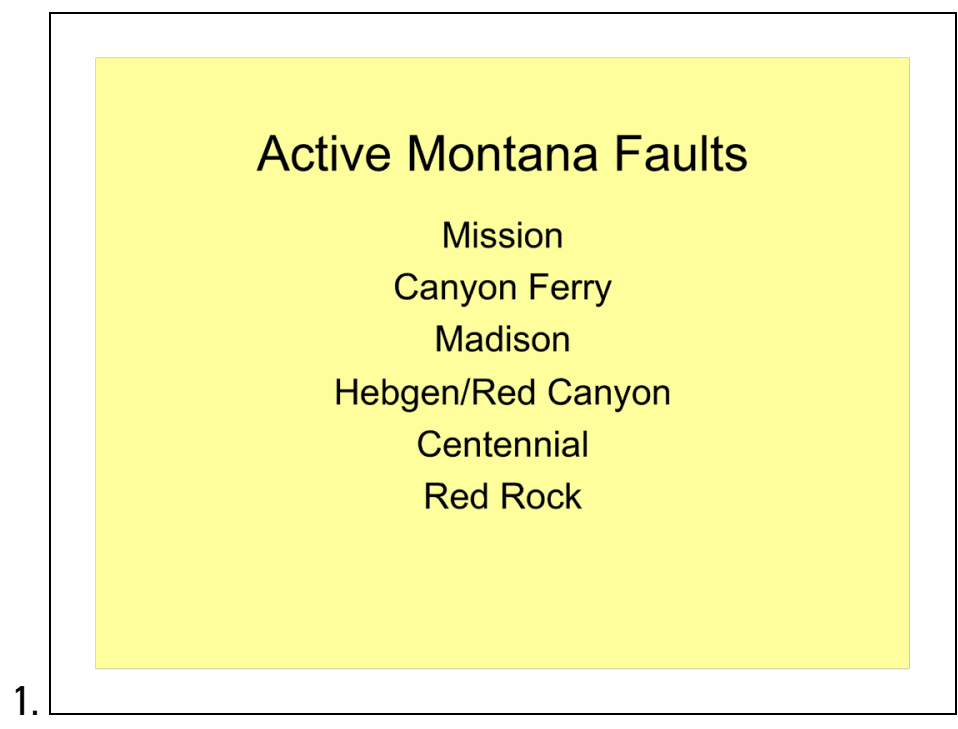

Ostenaa, Levish and Klinger released the Mission Fault Study as US Bureau of Reclamation Seismotectonic Report 94-8 in 1995.

Significant findings include:

Maximum Credible Earthquake is 7.5 (Ms)

Most recent event is $7.7 \pm 0.2 \mathrm{kyr}$

Average recurrence interval is 4 to $8 \mathrm{kyr}$

“...the average recurrence interval could be less than the elapsed time, $7.7 \mathrm{kyr}$, since the most recent faulting event. This may imply a higher the Mission fault than might otherwise be assumed.
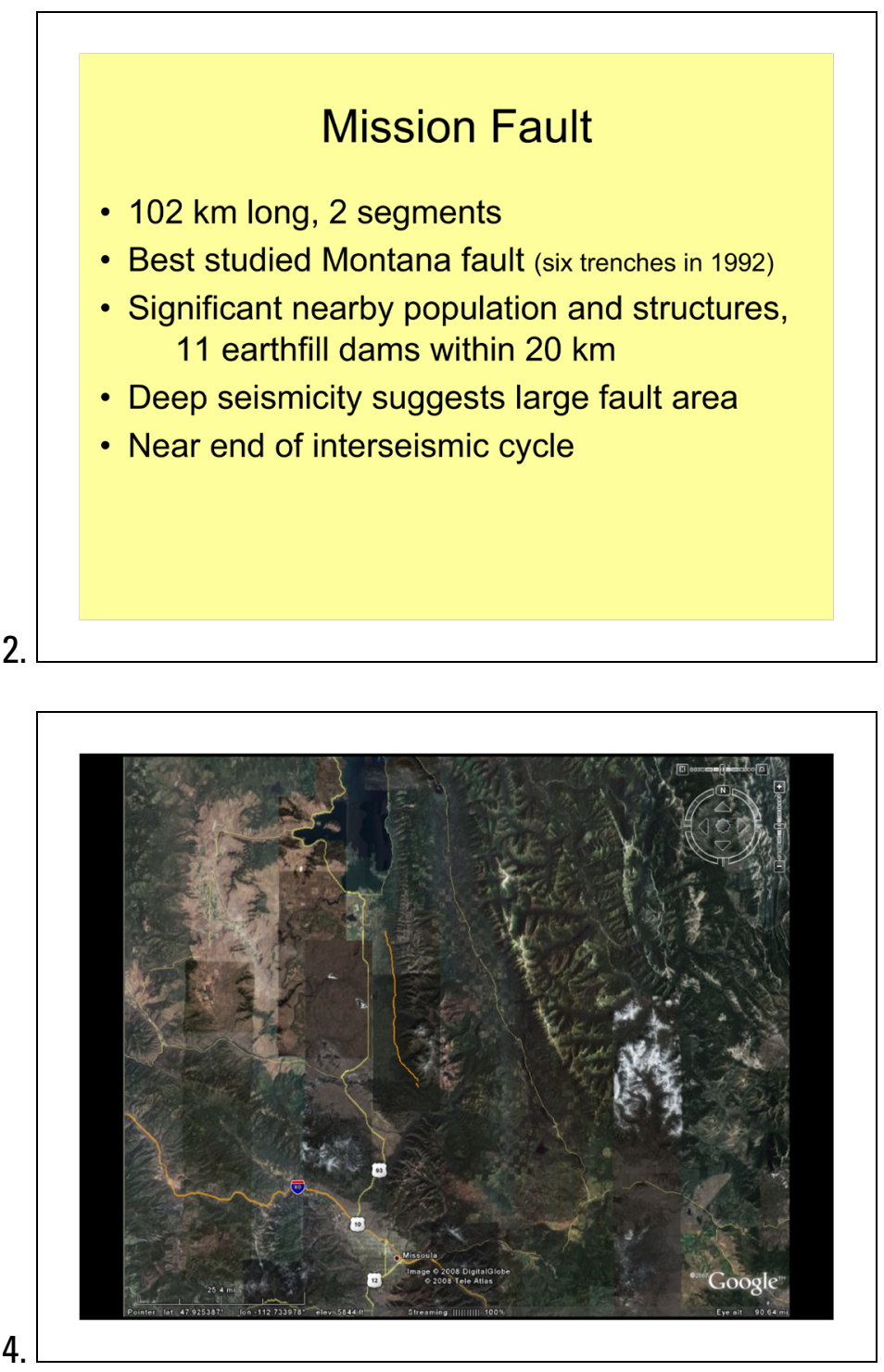


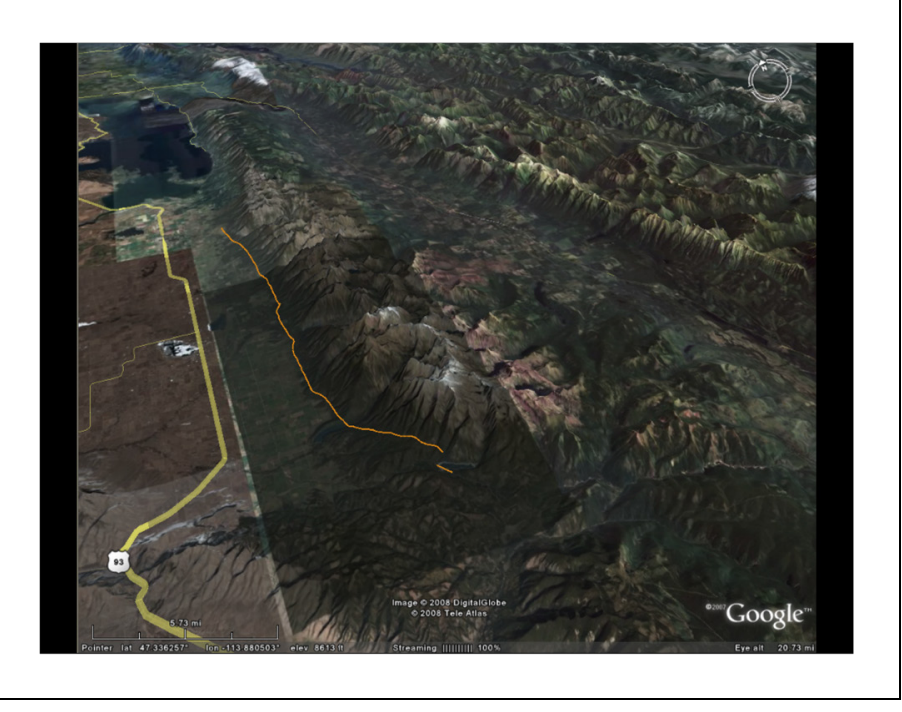

5.

\section{Canyon Ferry Fault}

- $35 \mathrm{~km}$ long, 2 segments

- One trench (USBR 2002)

- May produce $0.6 \mathrm{~g}$ ground acceleration at Canyon Ferry Dam, $<3 \mathrm{~km}$ from fault trace

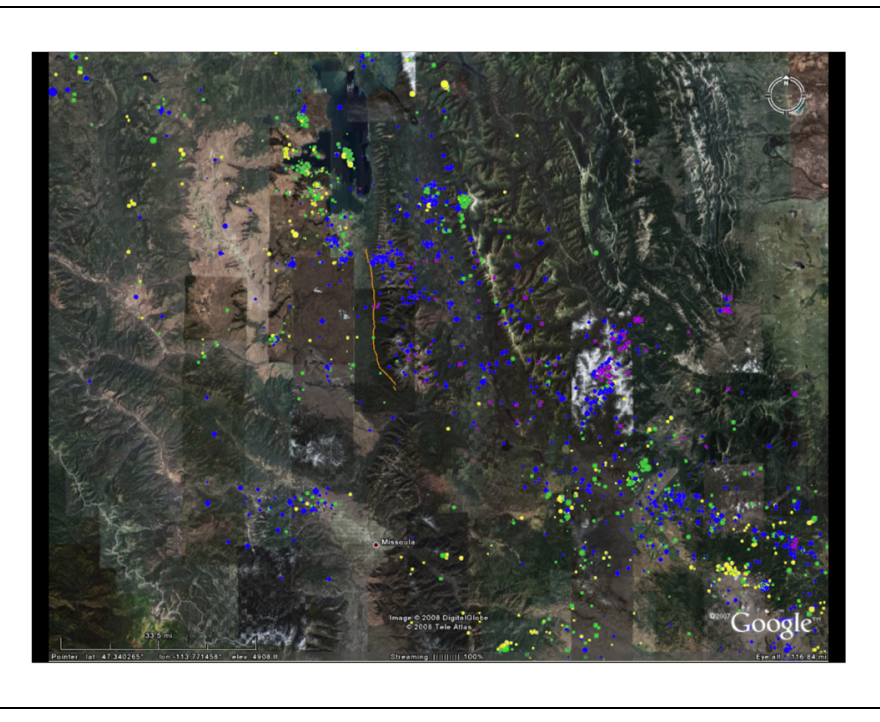

Anderson and LaForge released the Canyon Ferry Dam Seismotectonic Study as US Bureau of Reclamation Seismotectonic Report 2003-1 in 2003.

Significant findings include:

Range of maximum $\mathbf{M}$ is 6.9-7.2

2 and probably 3 events between 13 and $21 \mathrm{ka}$

No events since $13 \pm 1 \mathrm{ka}$

Long-lerm slip rate of $0.16 \mathrm{~mm} / \mathrm{yr}$ but seismic clustering implies

short-term slip rate of nearly $1.0 \mathrm{~mm} / \mathrm{yr}$
Recurrence intervals could be $>13 \mathrm{ka}$ or as short as a few ka

"...the Canyon Ferry fault is longer and more active than previously thought."
7.
8. 


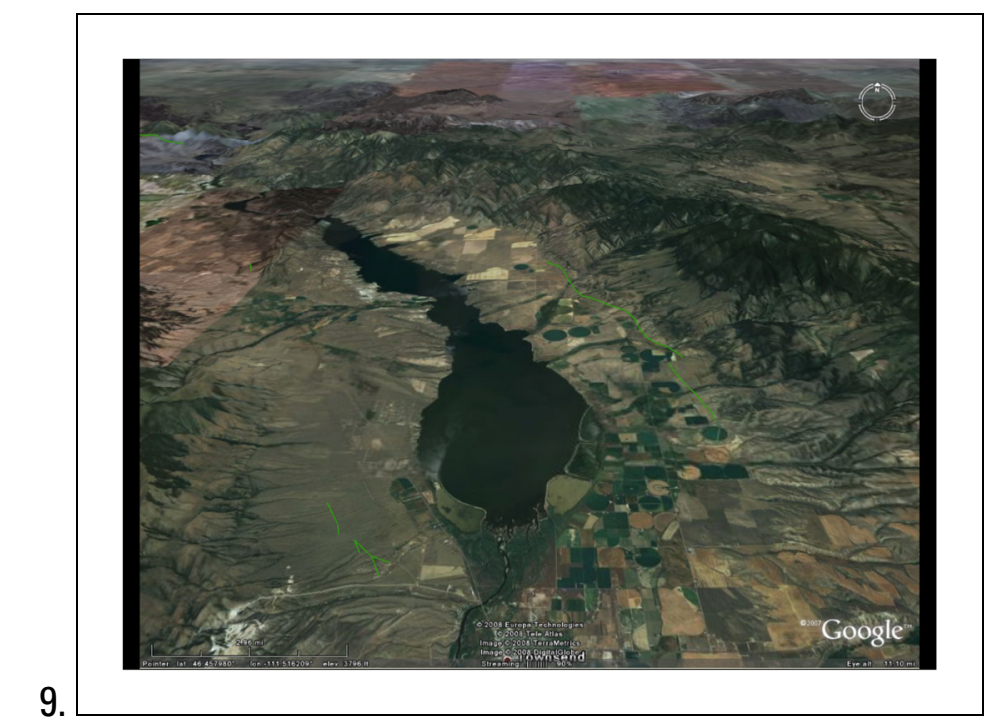

9.

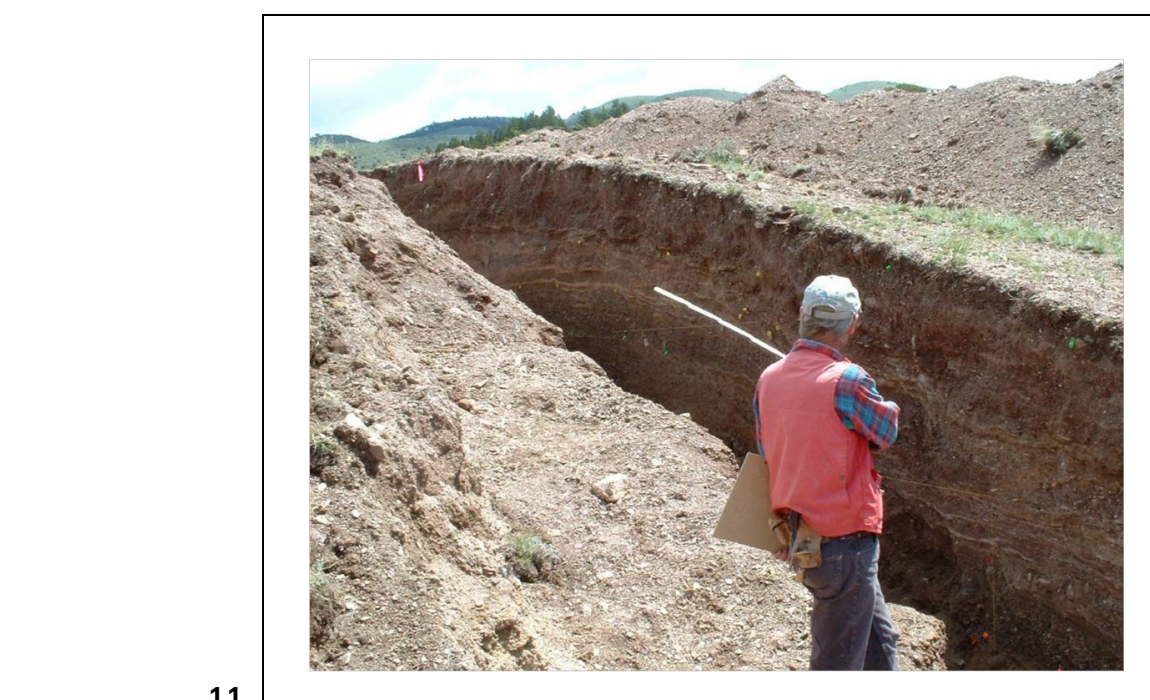

11.
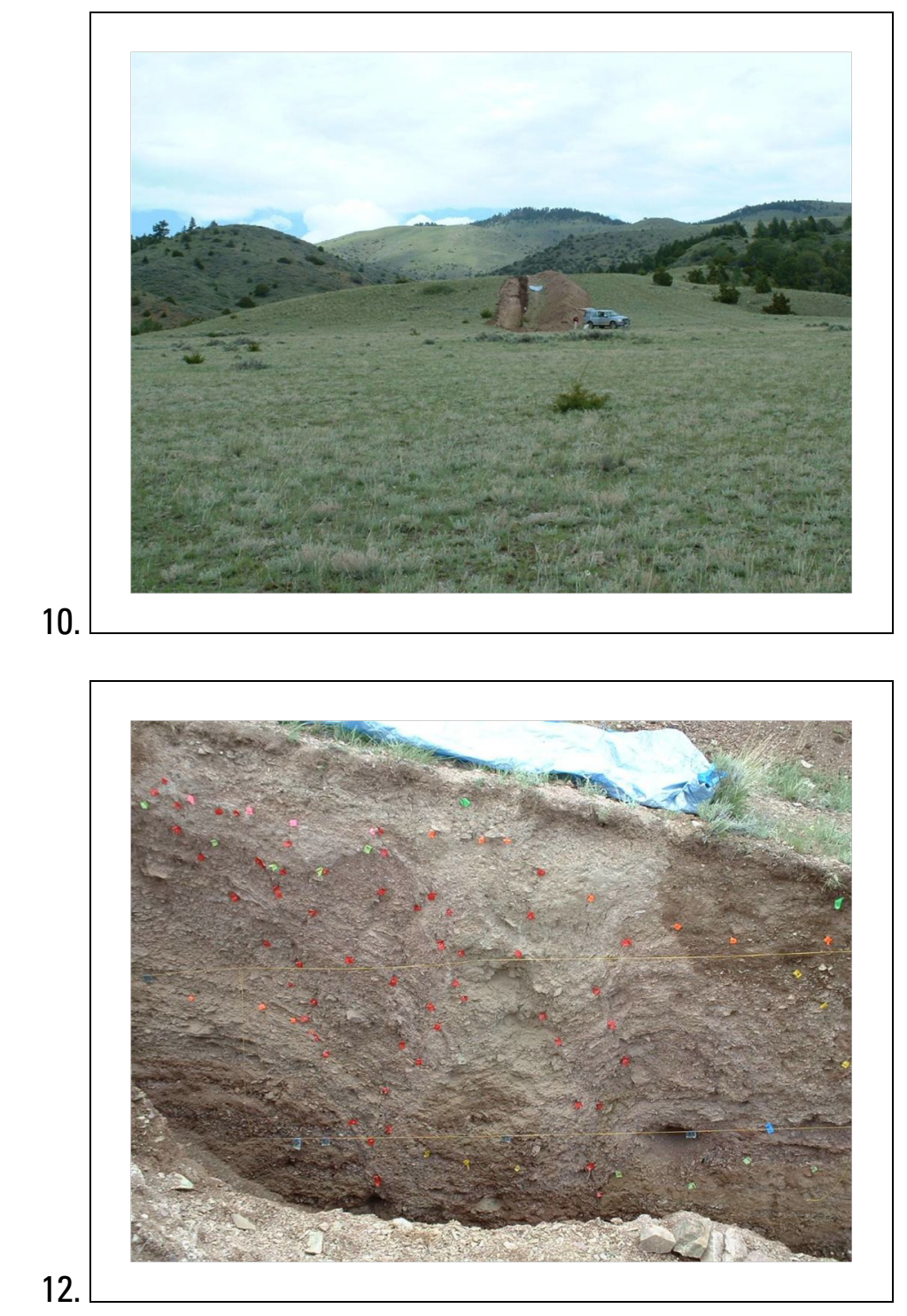


\section{Madison Fault}

- 99 km long, 3 segments

- No trenches

- Minor reactivation of a short section in 1959
13.

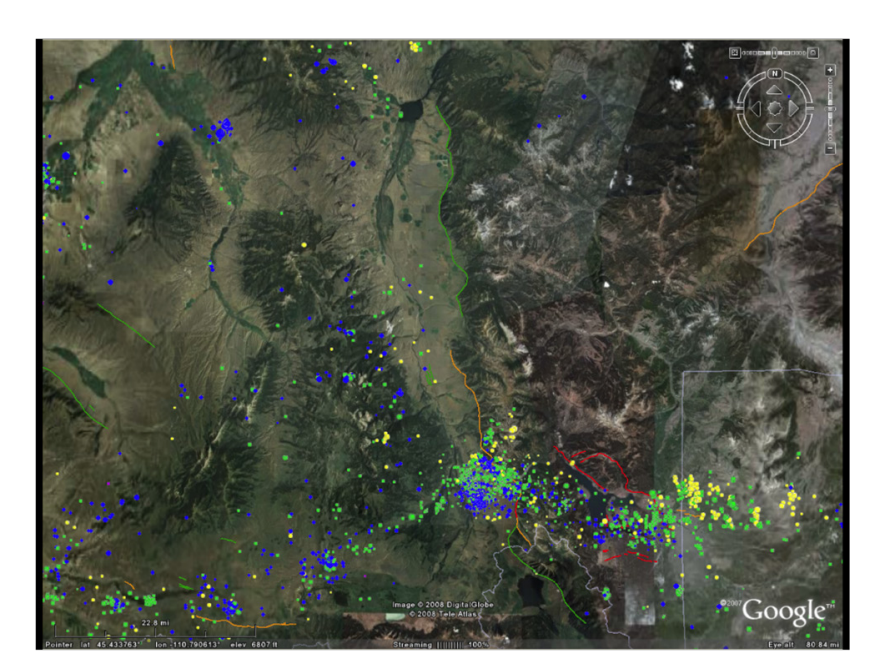

15.

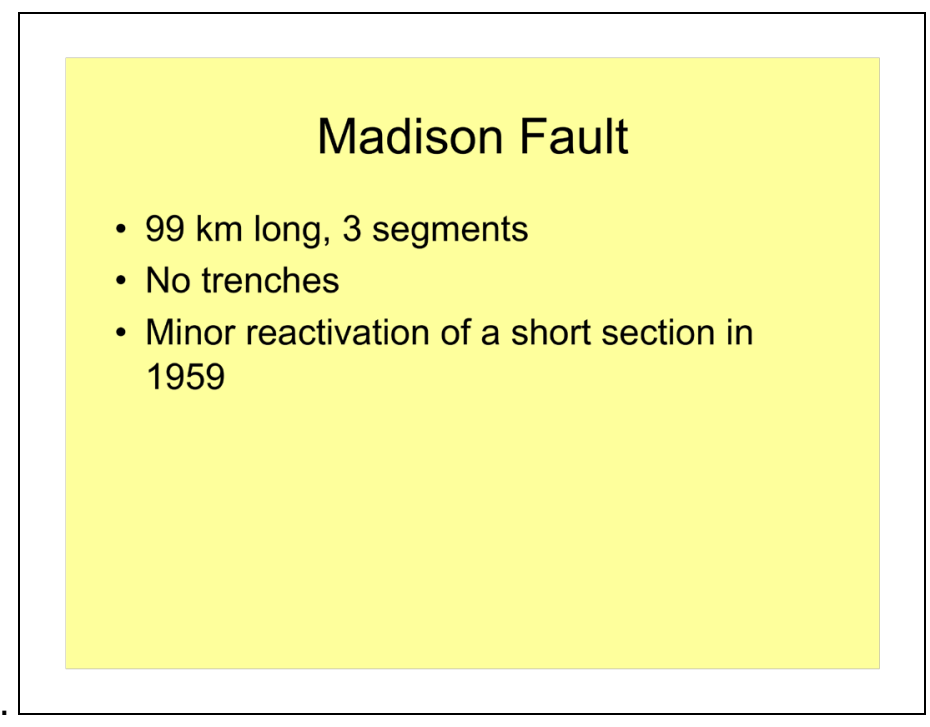

14.

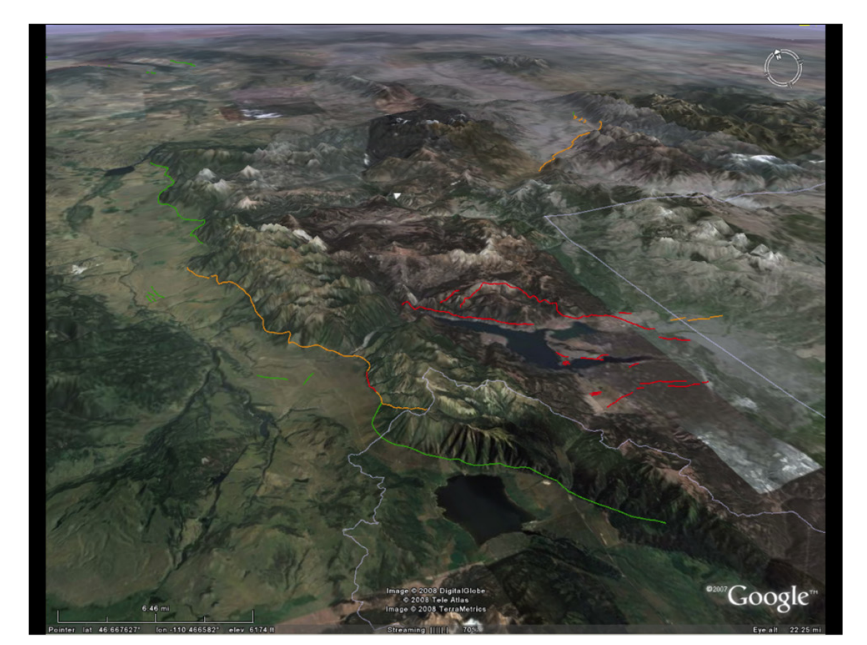

\section{Hebgen/Red Canyon faults}

- Historic rupture in 1959, $\mathbf{M}=7.3$

- 29 deaths despite a low population density

- $\$ 11$ million in damages to roads and bridges (\$78 million in today's dollars)

- 4 trenches excavated in 2000

- The Cabin Creek trench showed only one pre-1959 Holocene faulting event
16. 

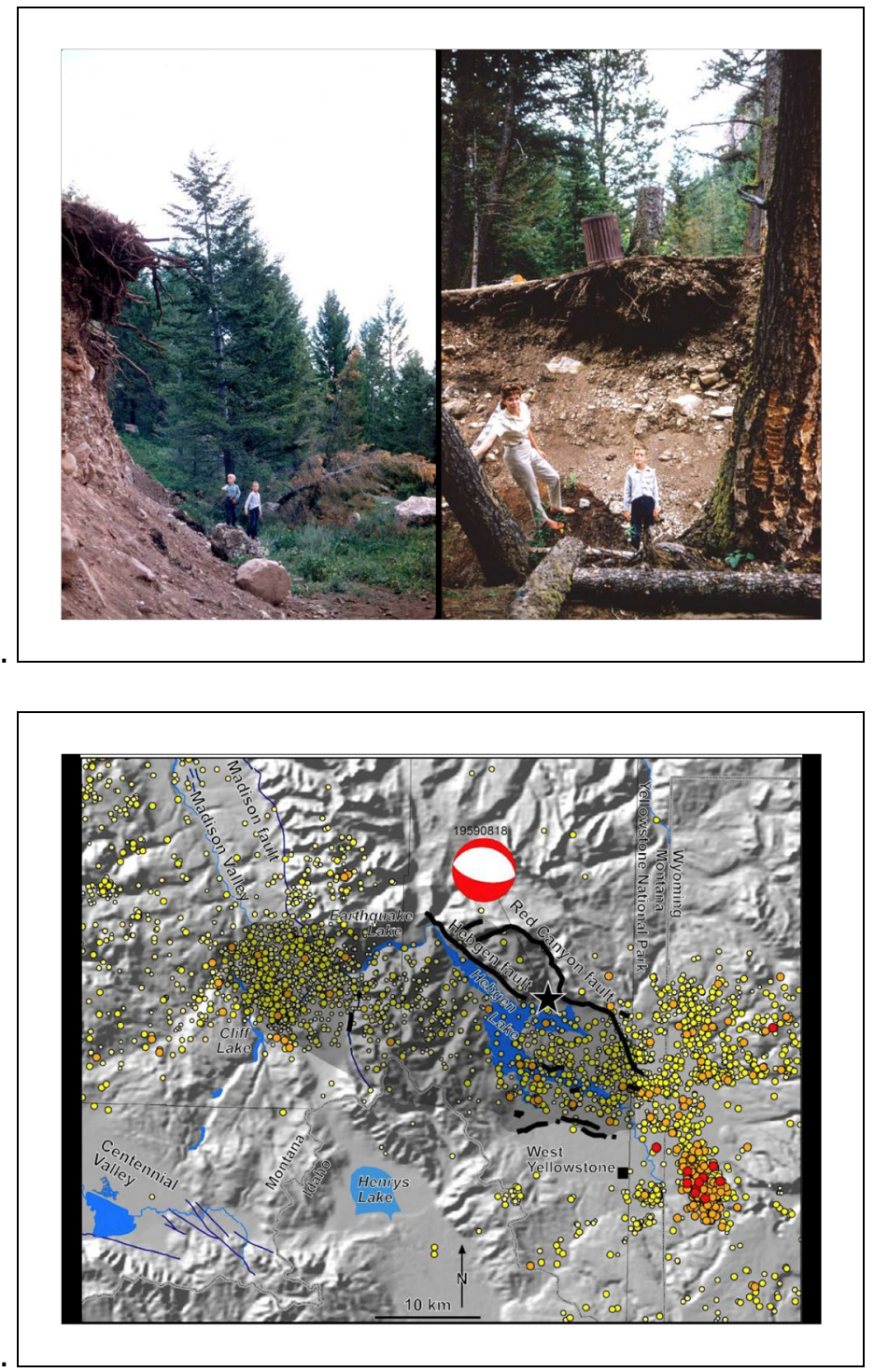

18.

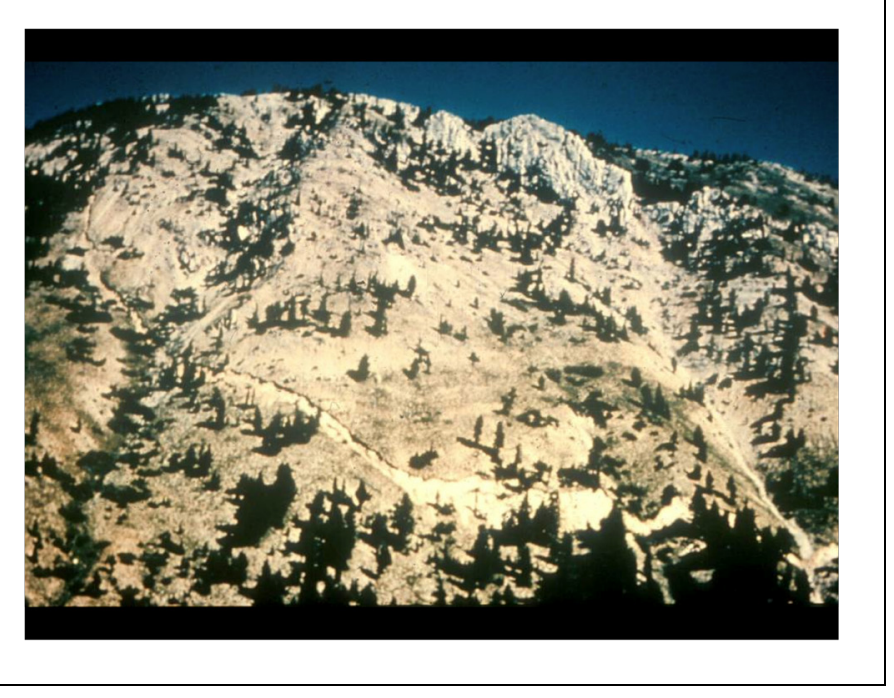

\section{Centennial Fault}

- $63 \mathrm{~km}$ long, 3 segments

- No trenches

- Largest slip rate in Montana, $1.3 \mathrm{~mm} / \mathrm{yr}$

- Lima Dam lies within 15 km
20. 


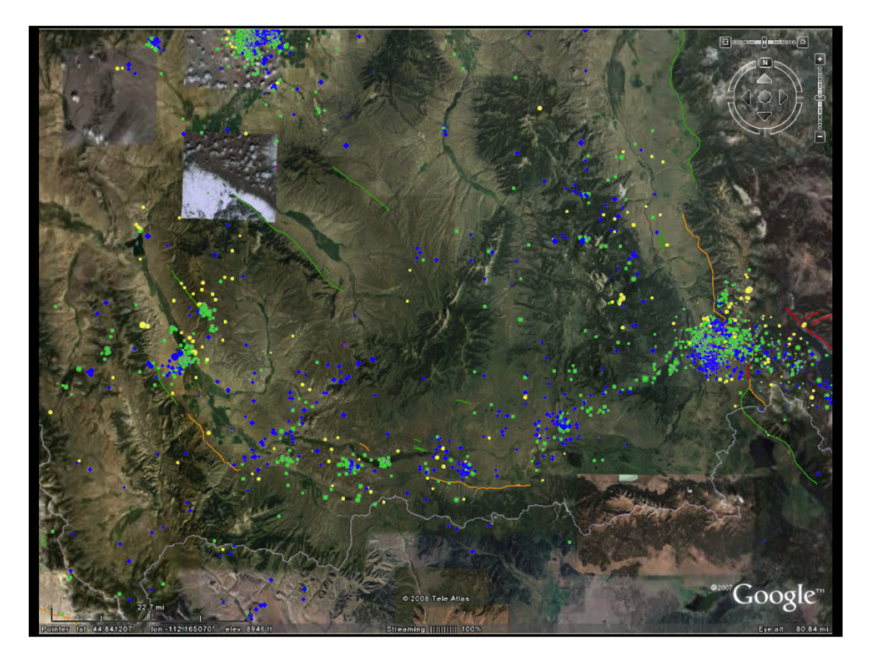

21.

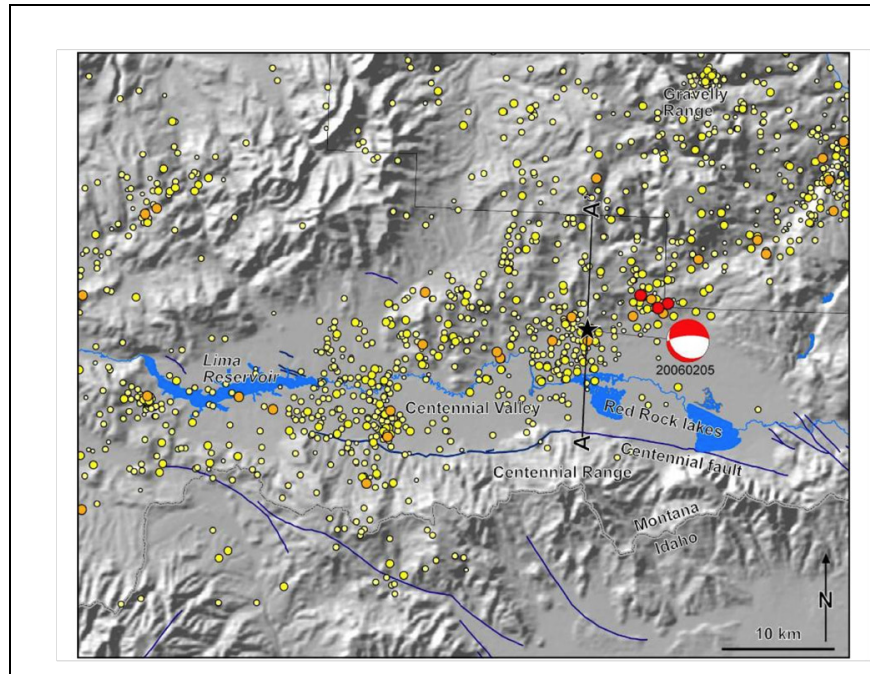

23.

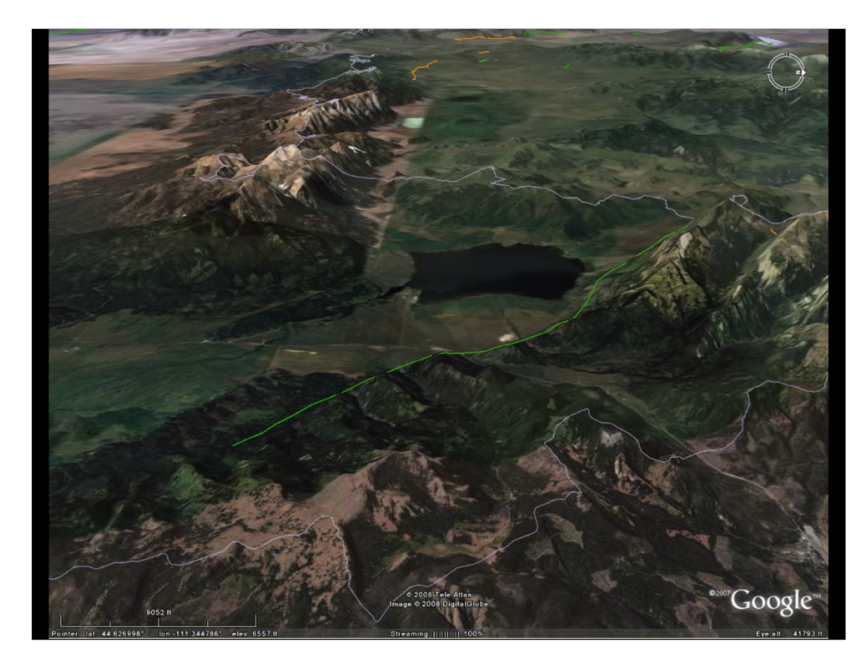

22.

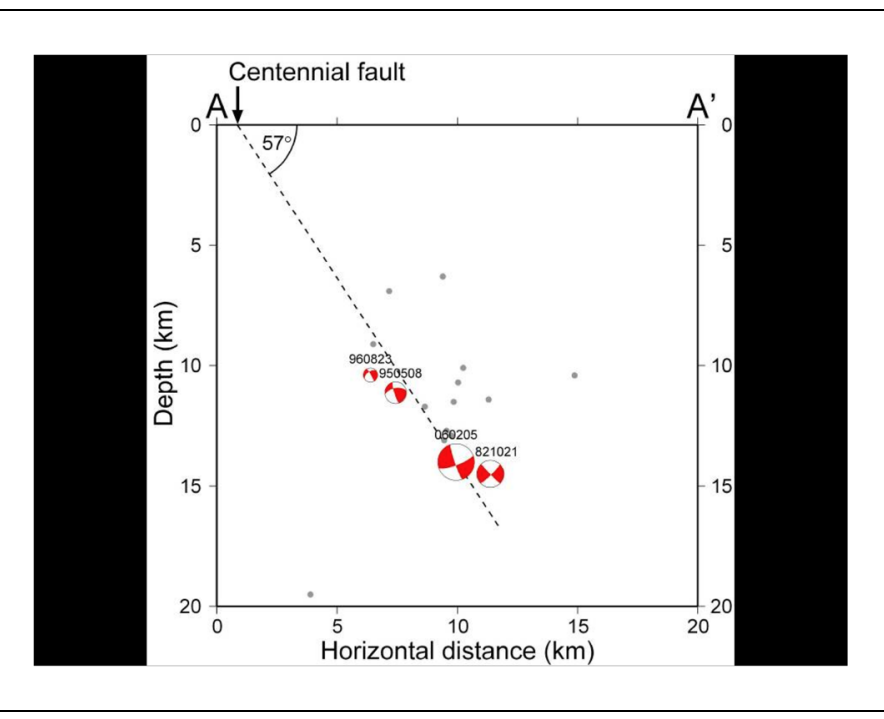




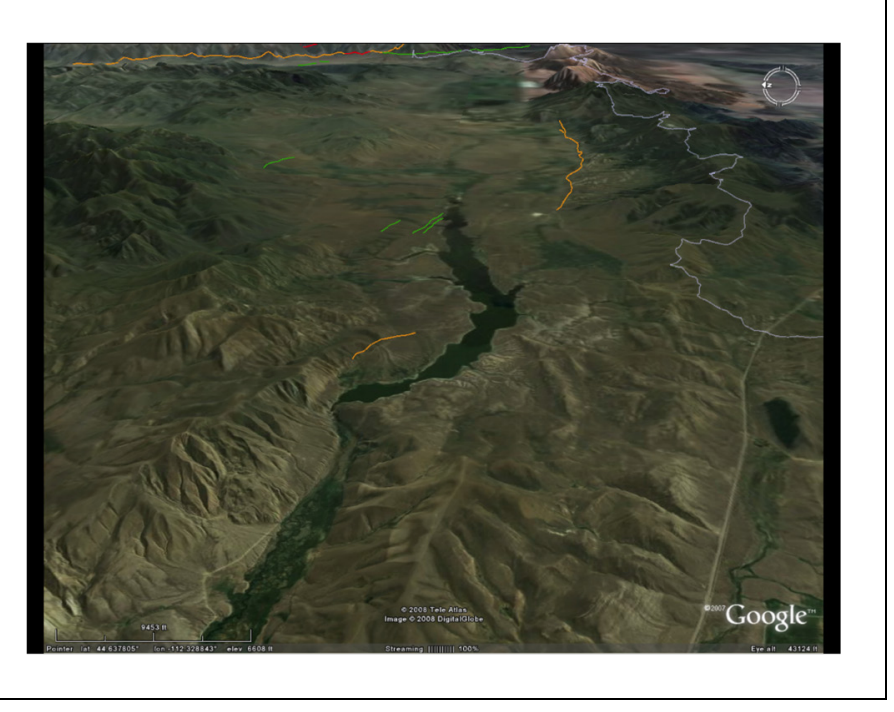

25

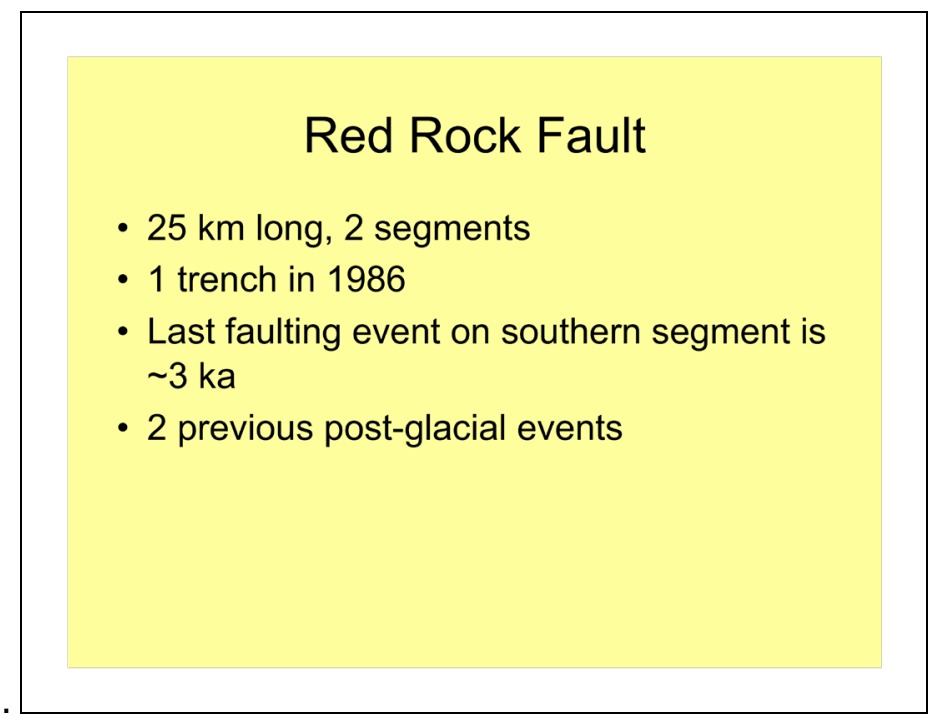

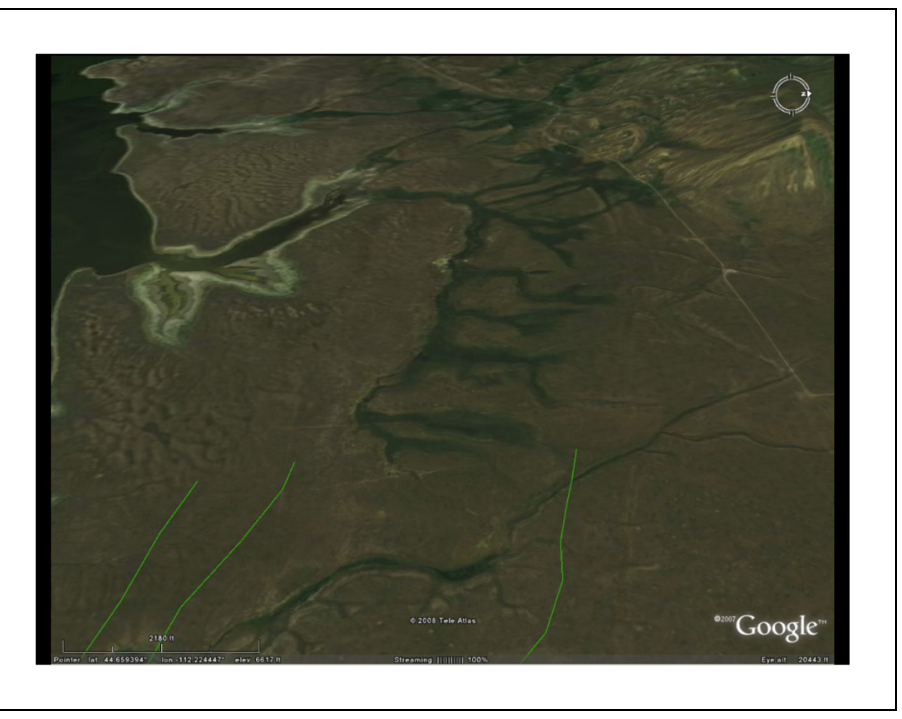

26.

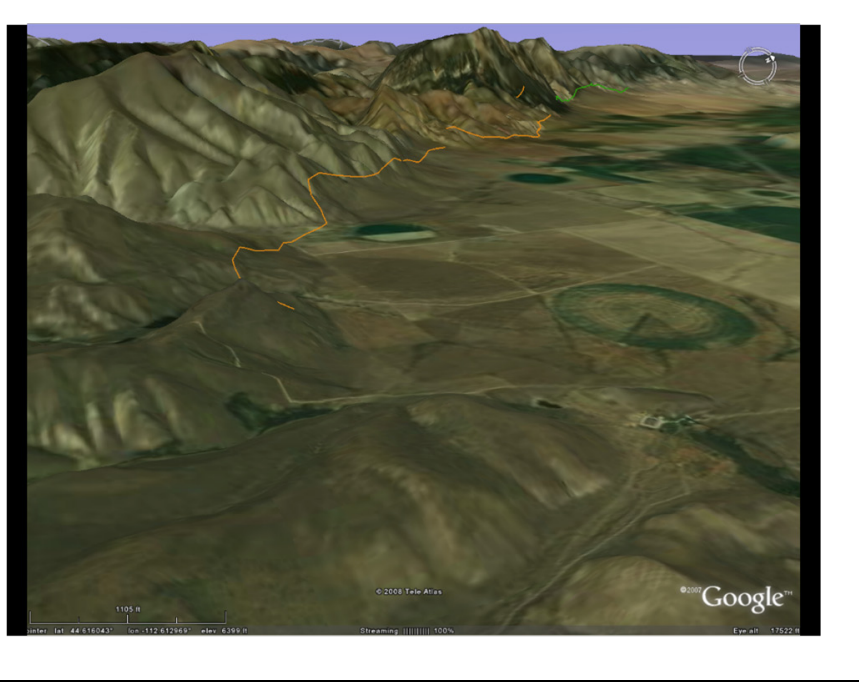

28. 


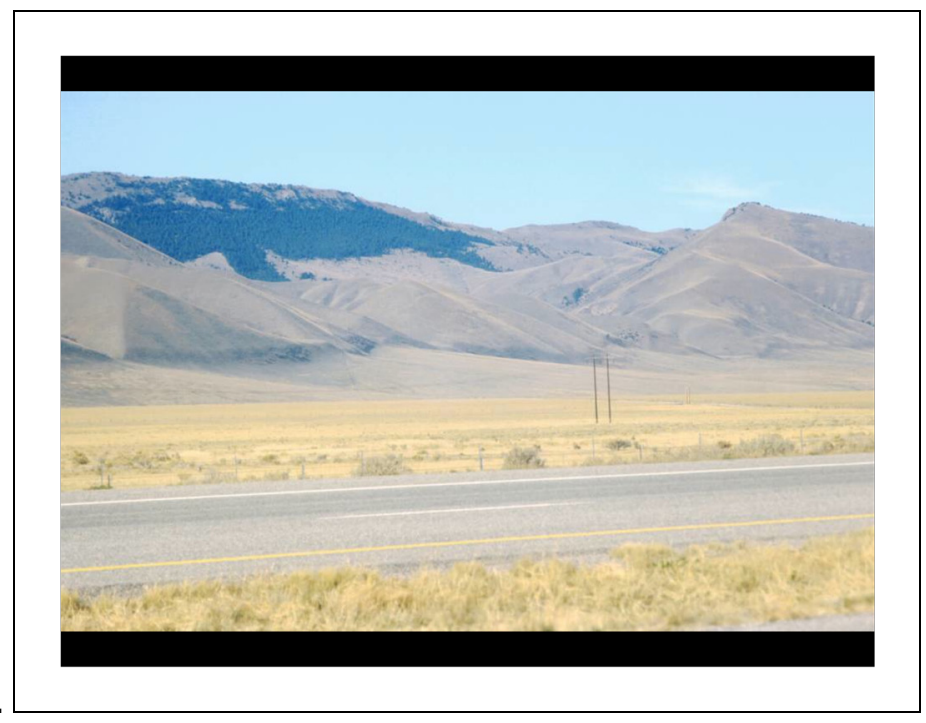

29.

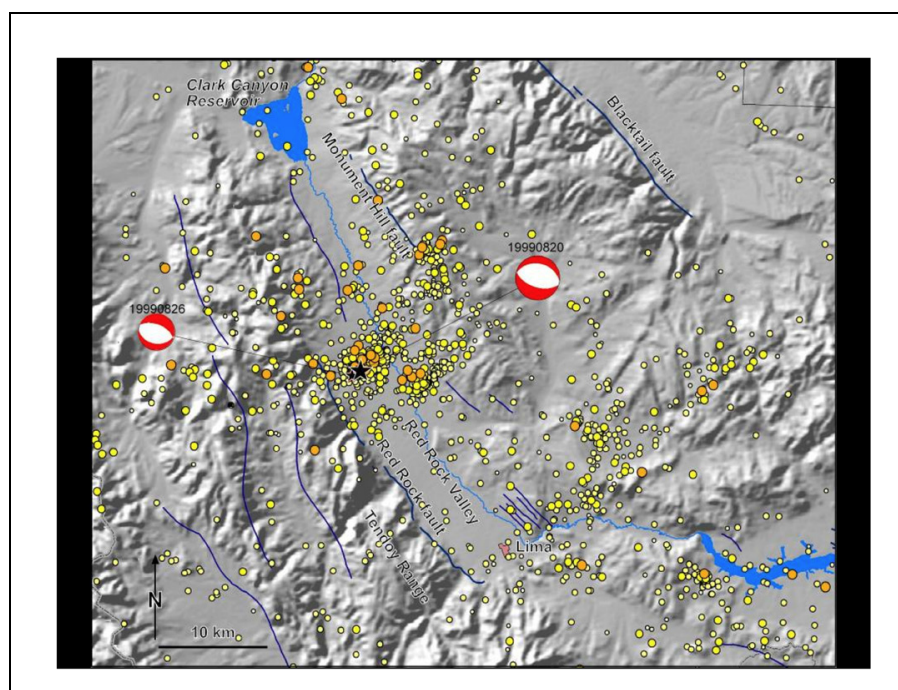

31.

32.

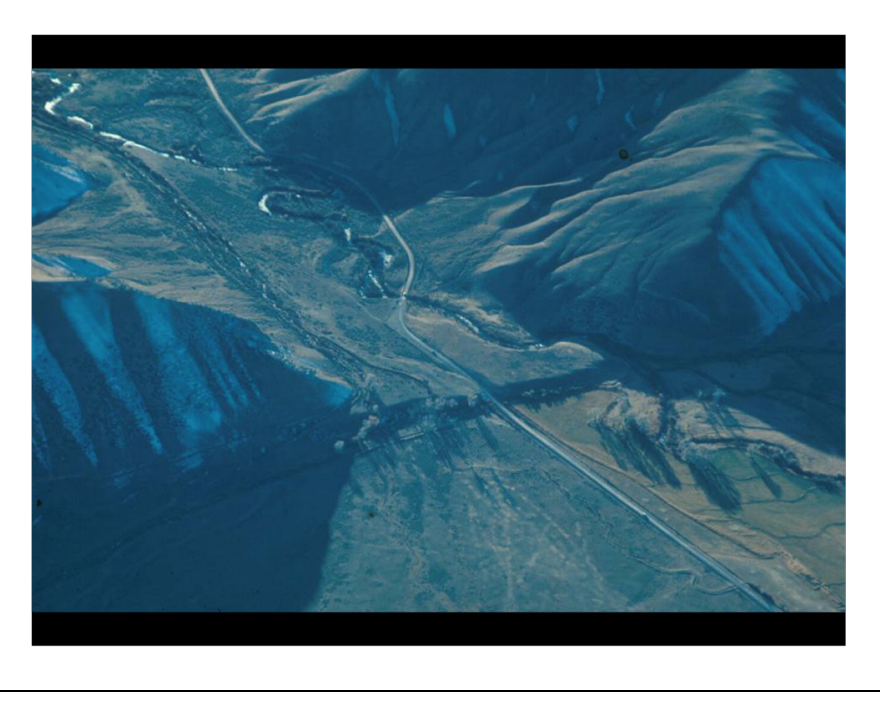

30.

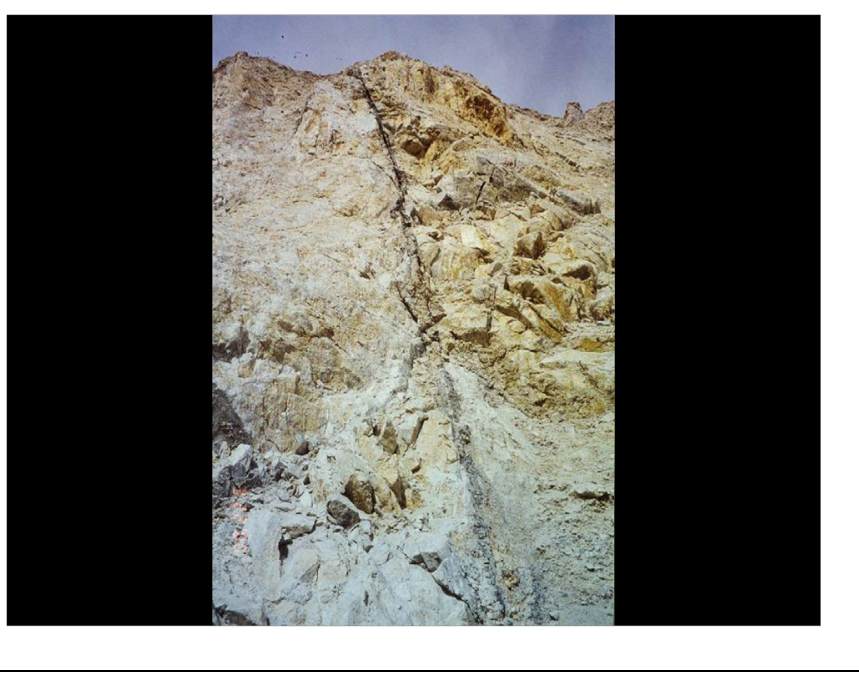




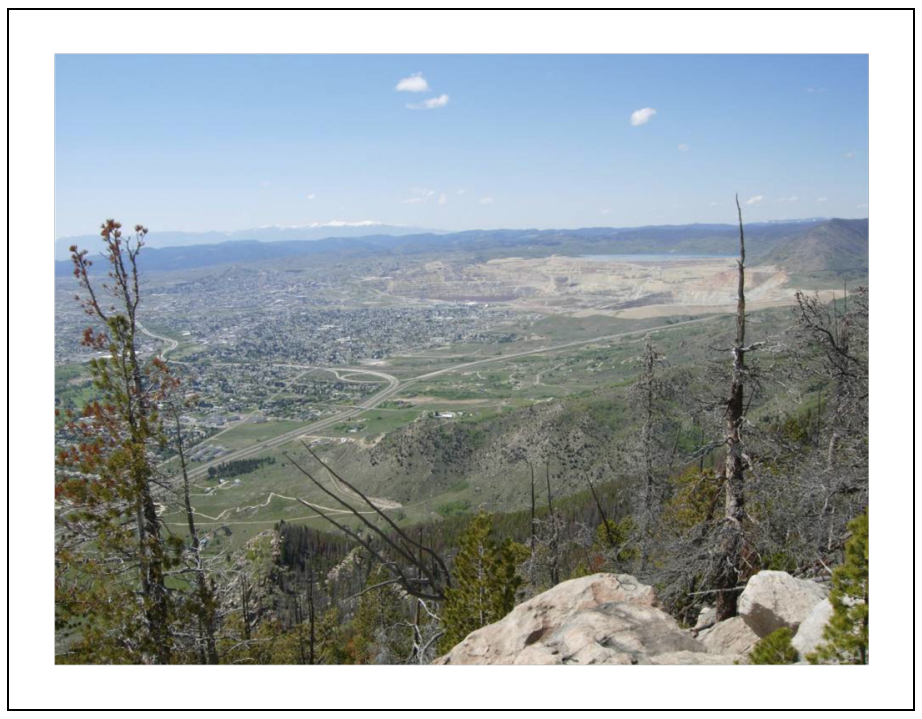

33.

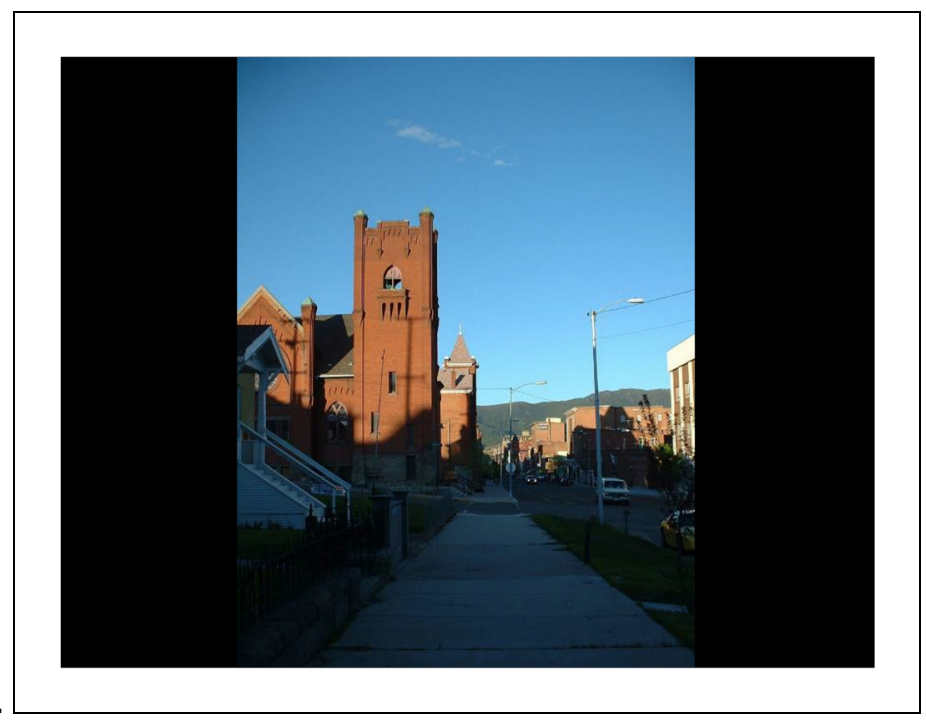

34.

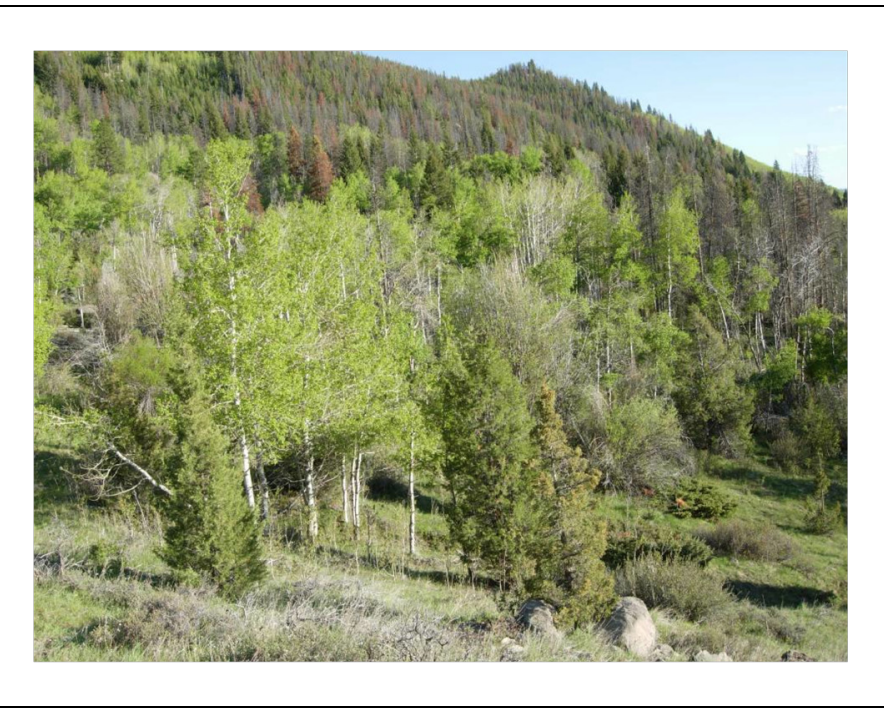

\section{Conclusions}

- Most of the Quaternary faults in Montana remain largely unstudied-even the wellknown ones

- There are many "surprises" remaining to be discovered

- We need LiDAR imaging for identification and characterization of Montana faults
36. 
Appendix 3f. Hazardous Quaternary Faults in the Yellowstone area, Kenneth Pierce, U.S. Geological Survey
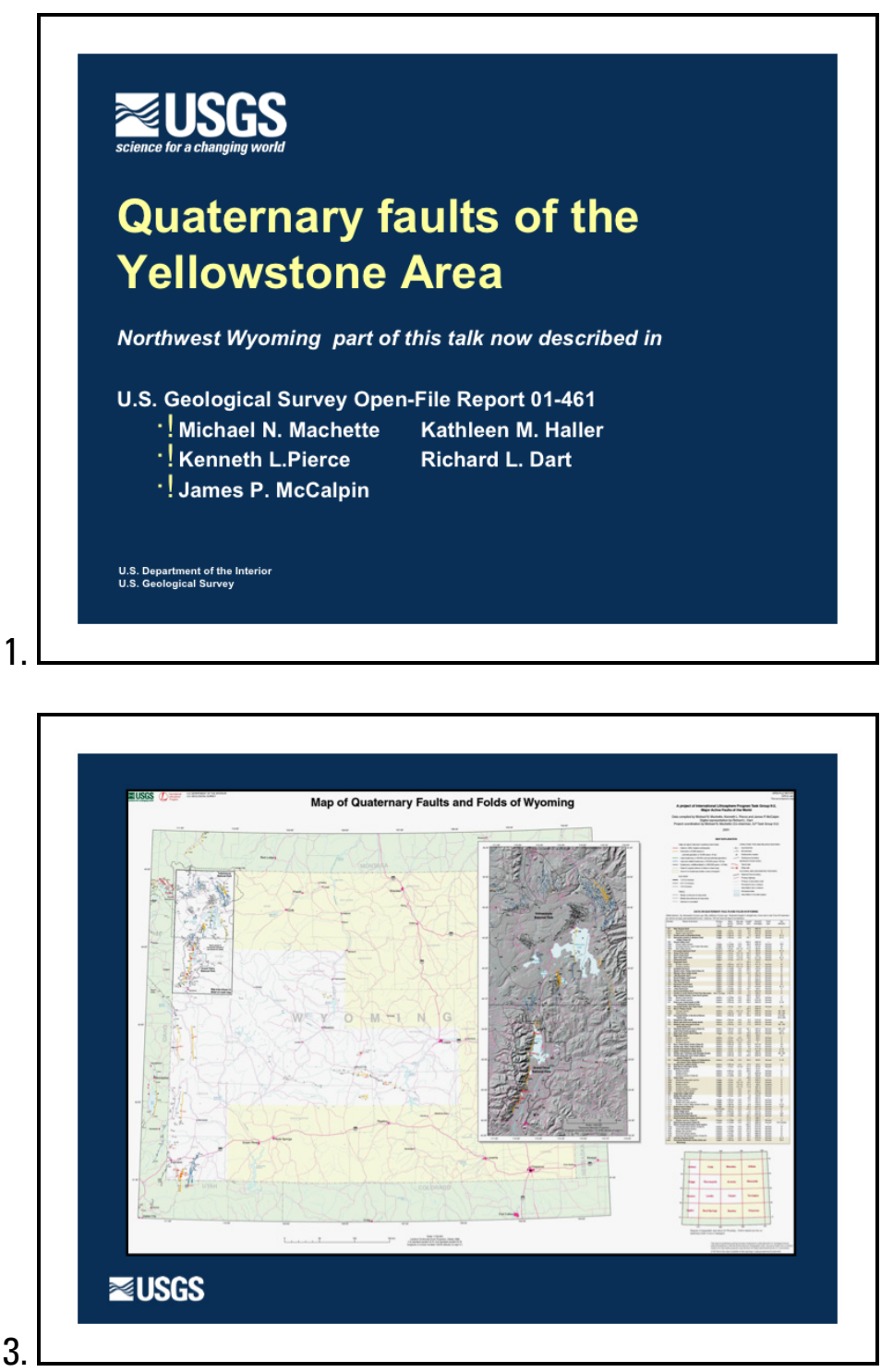
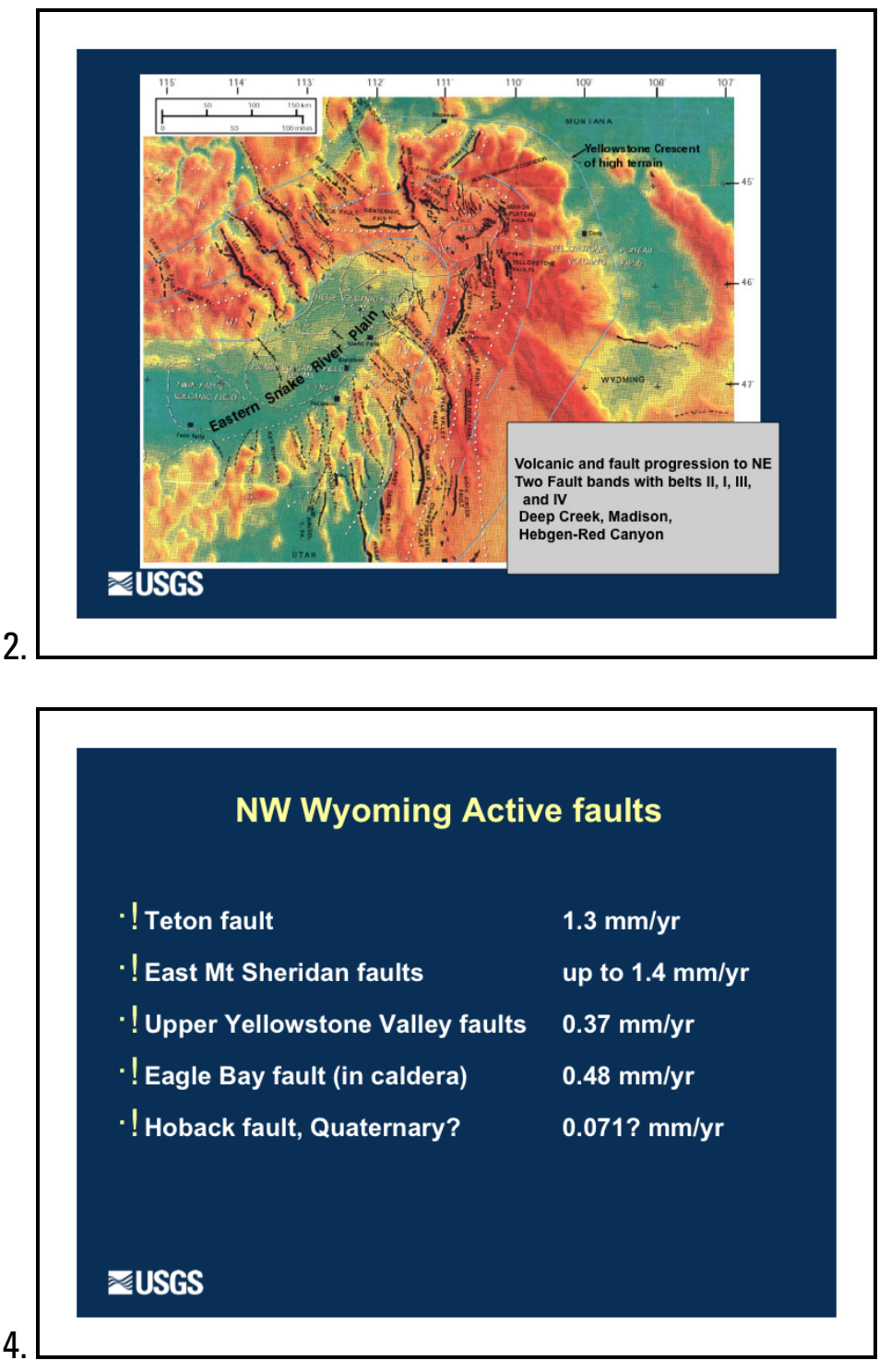

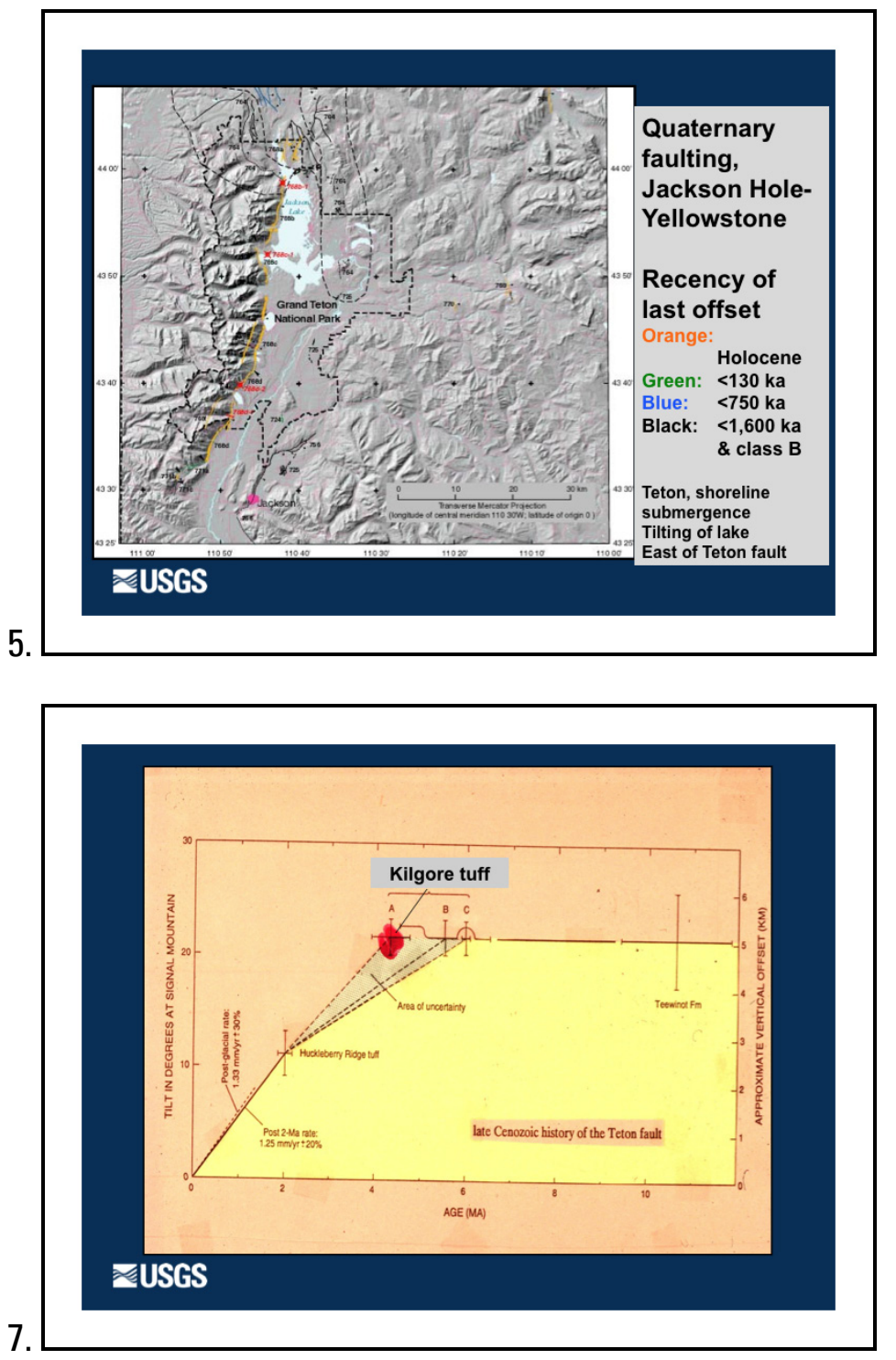
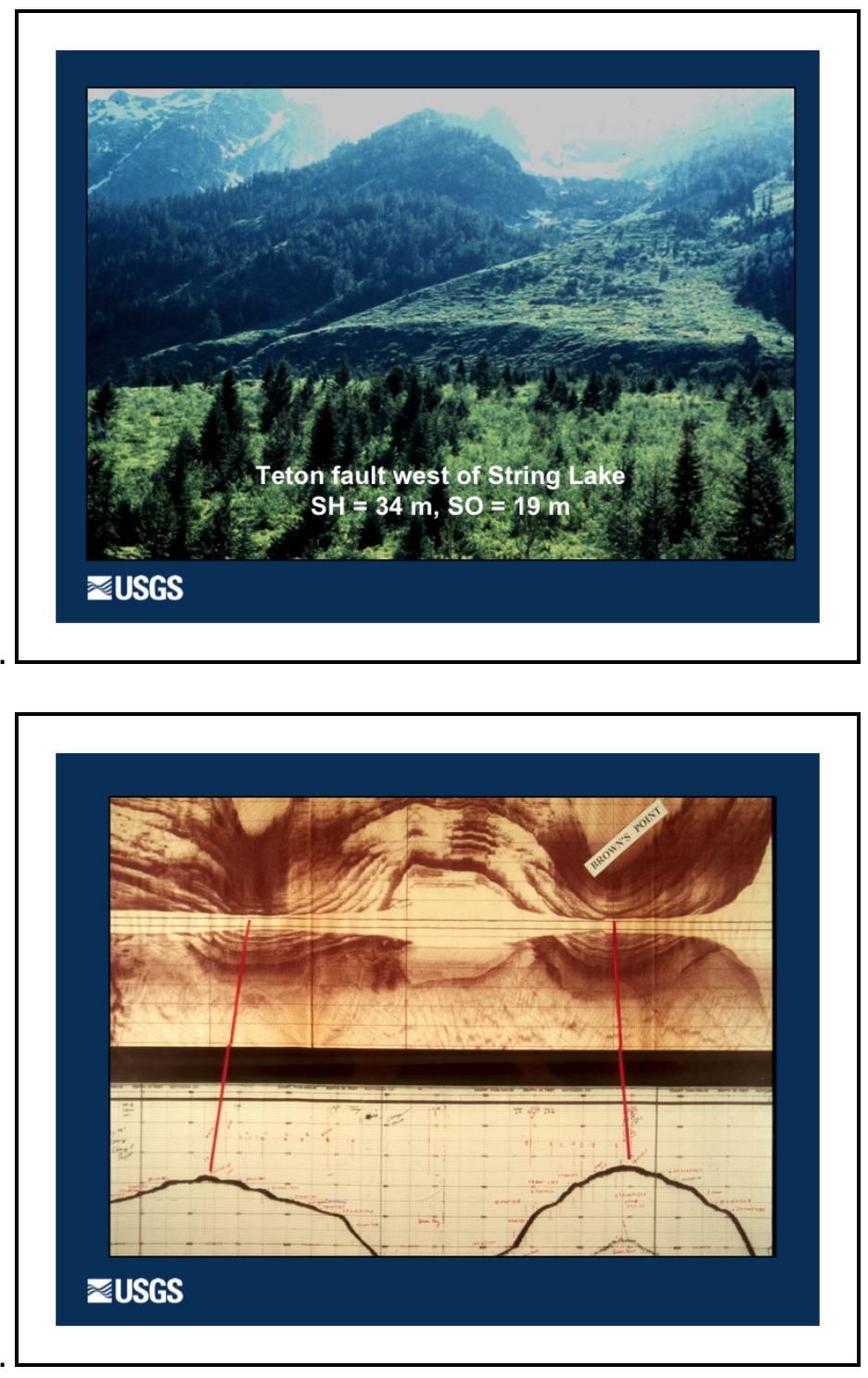
옥

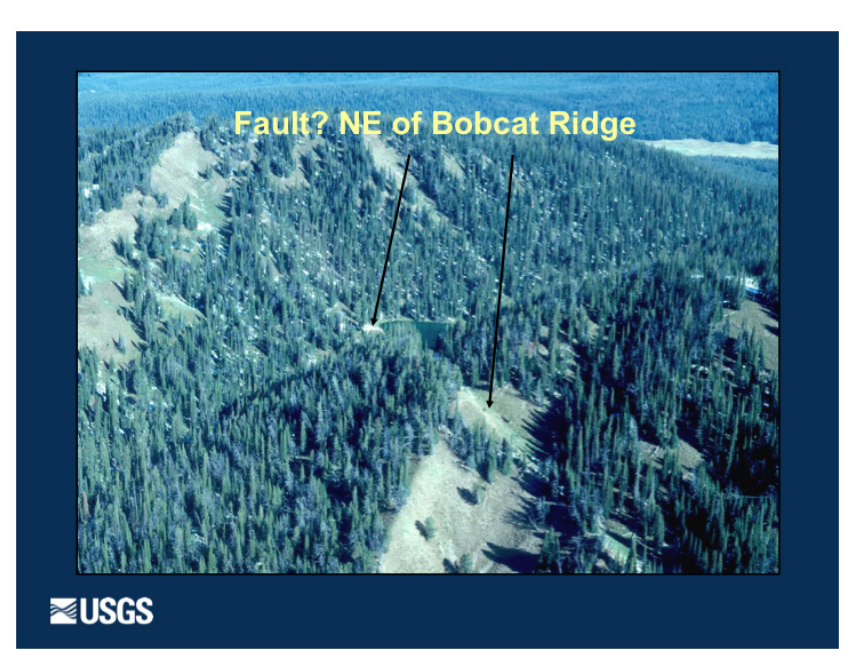

9.

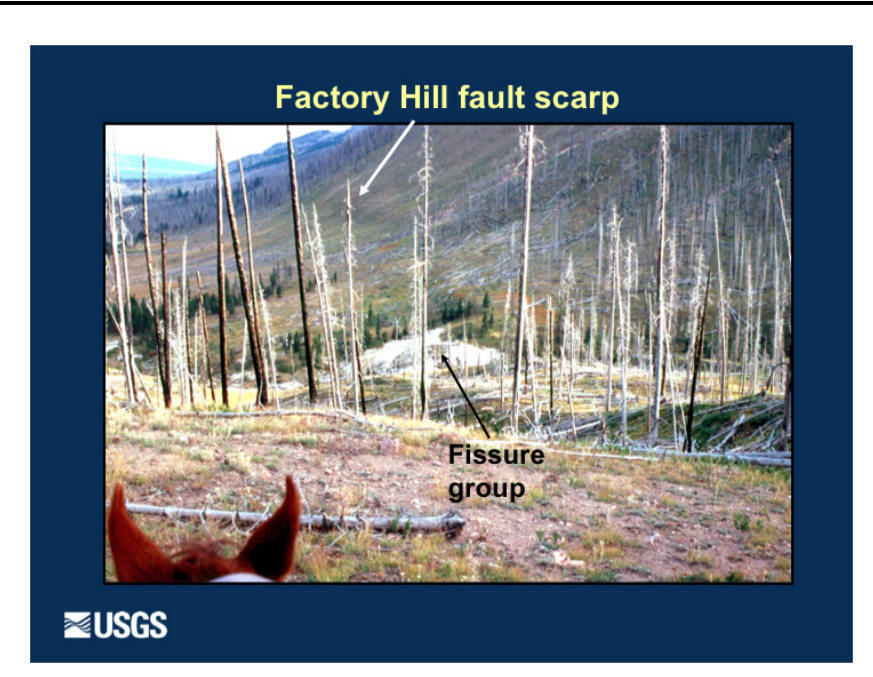

10.
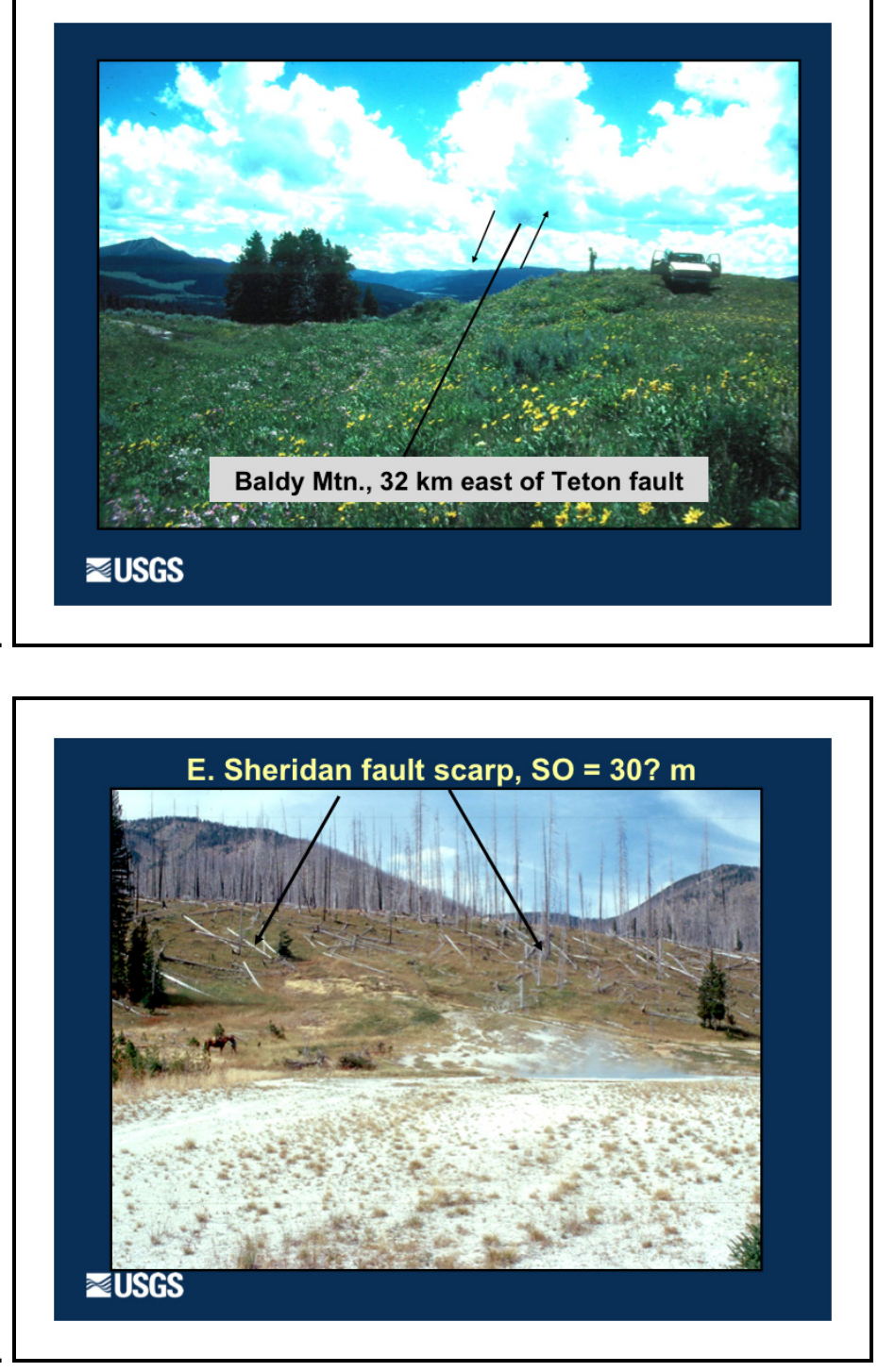

12.

11. 


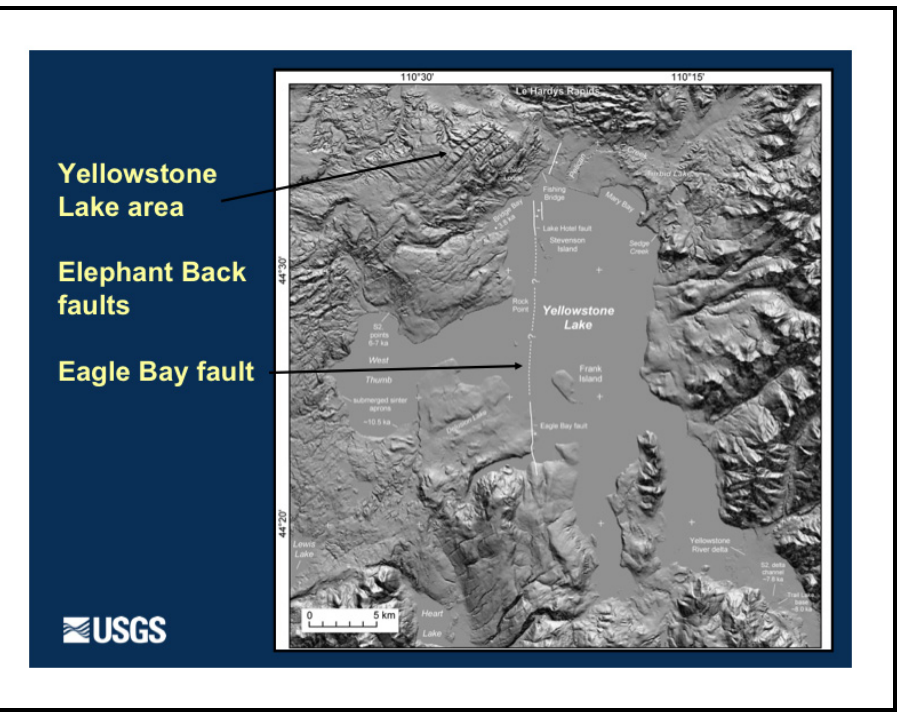

13.

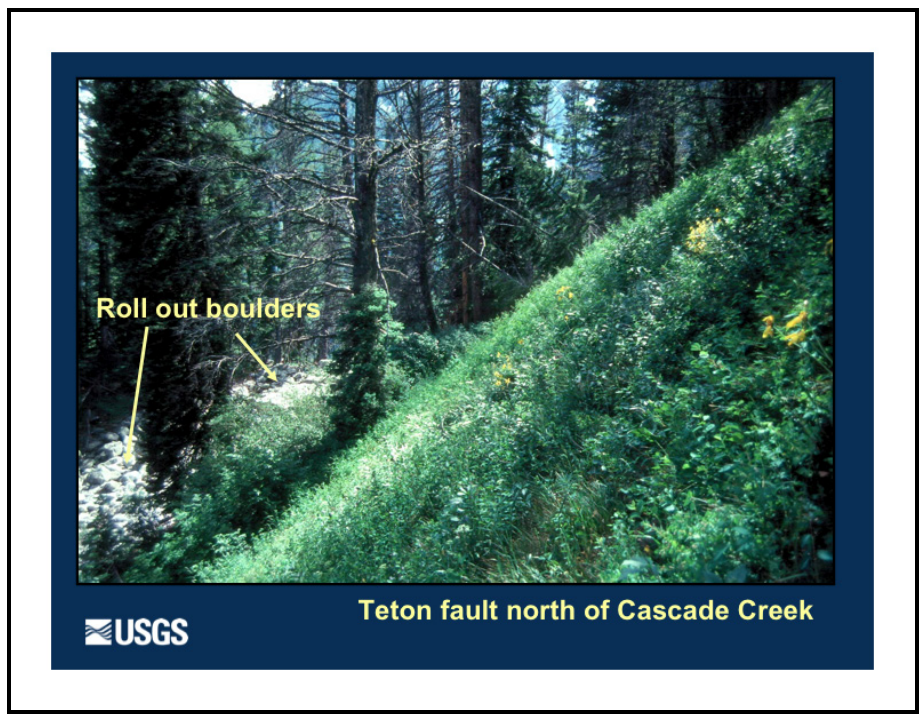

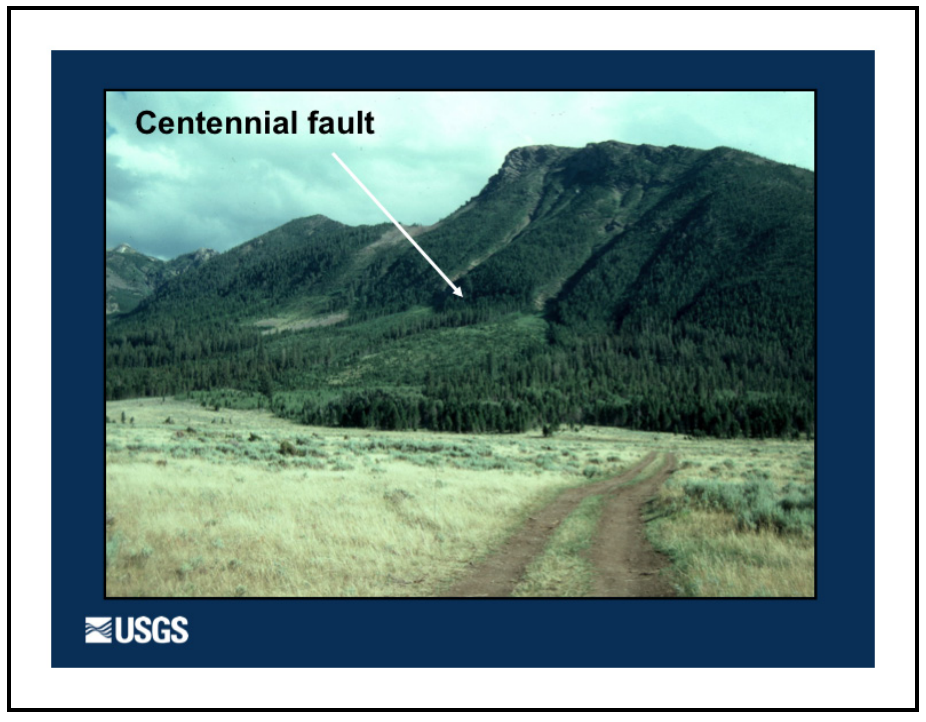

14.

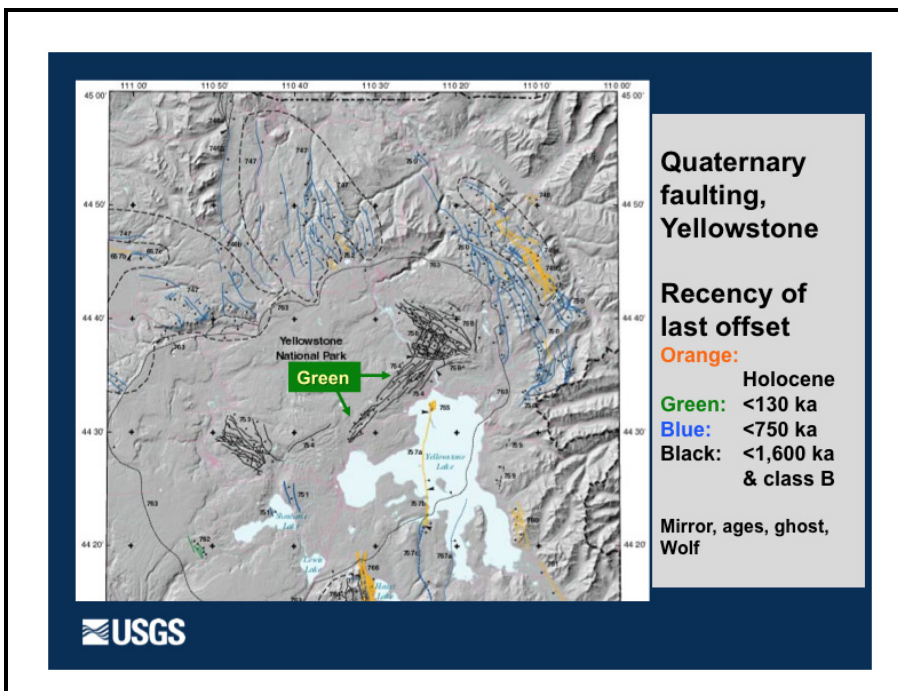

16. 

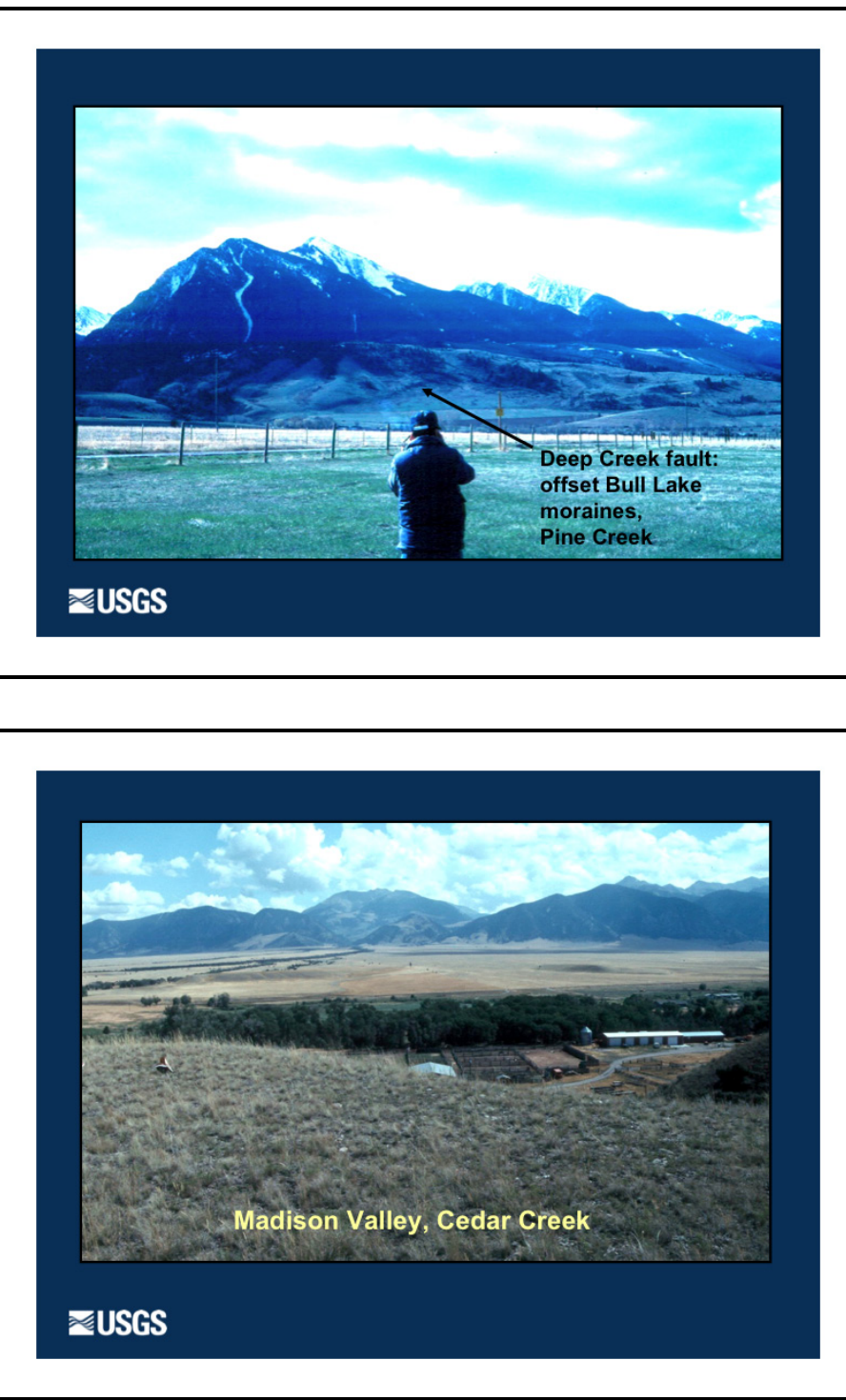

18.
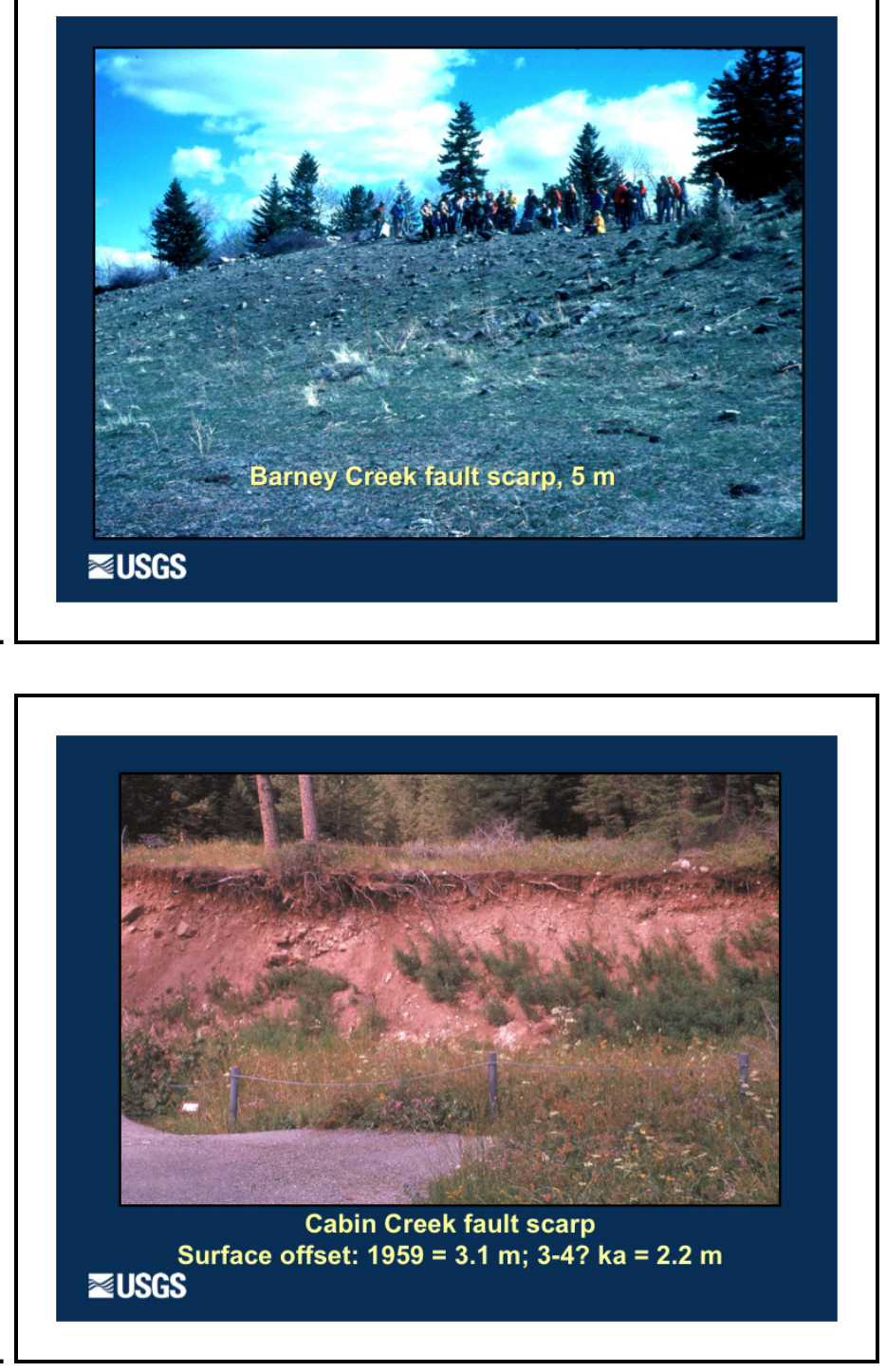

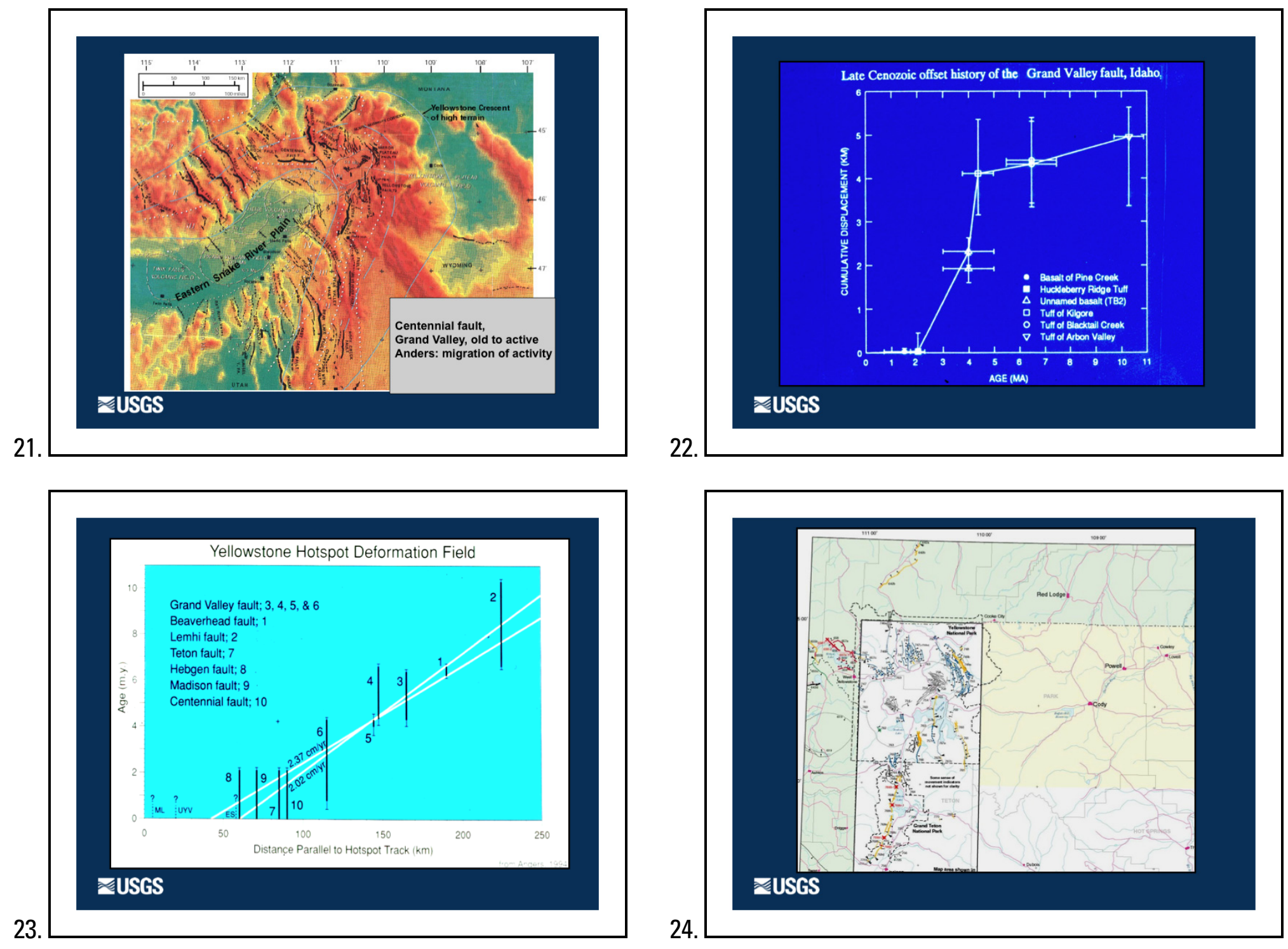

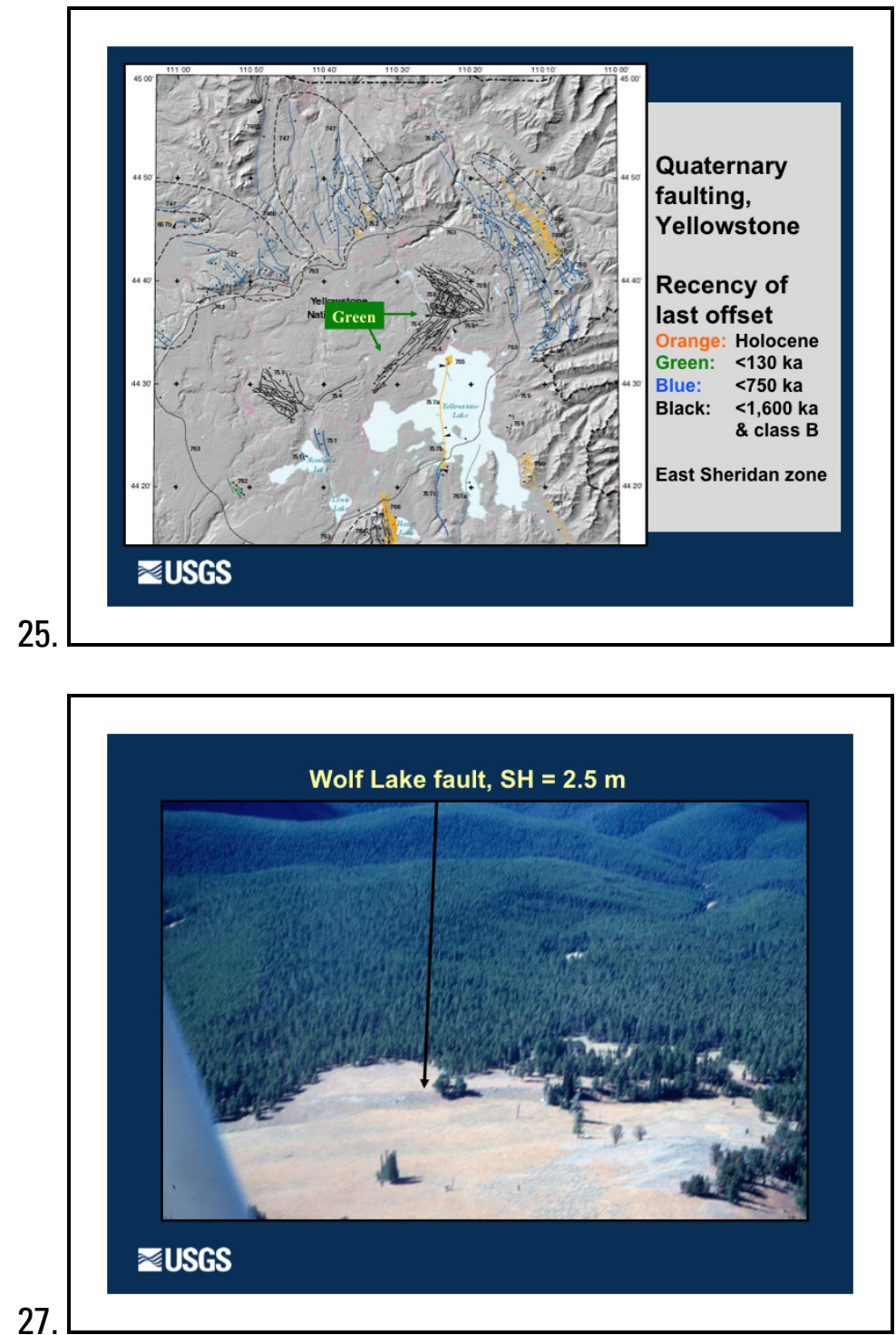

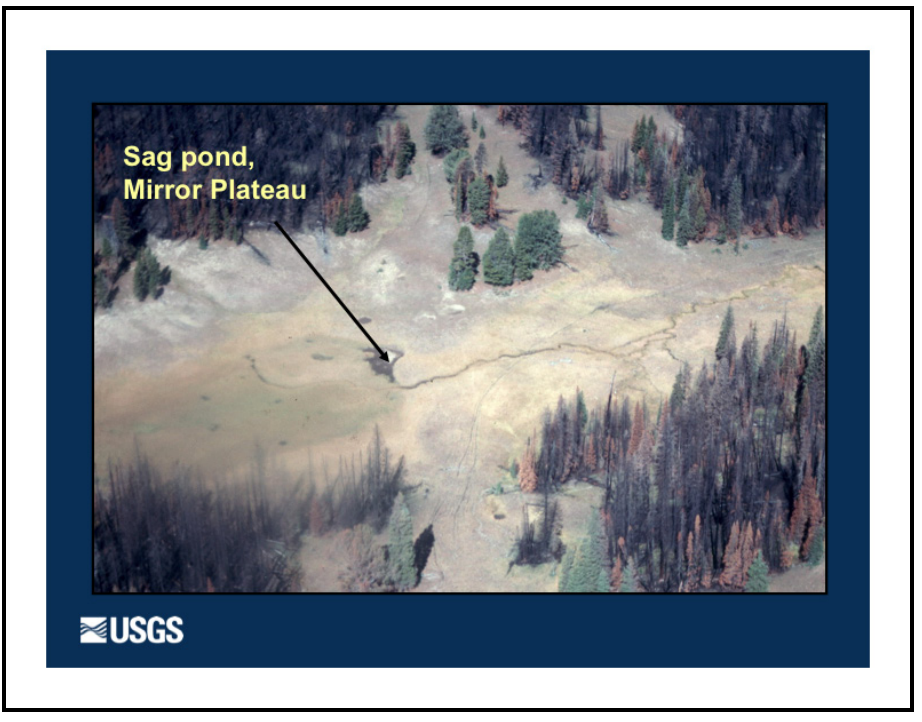

26.

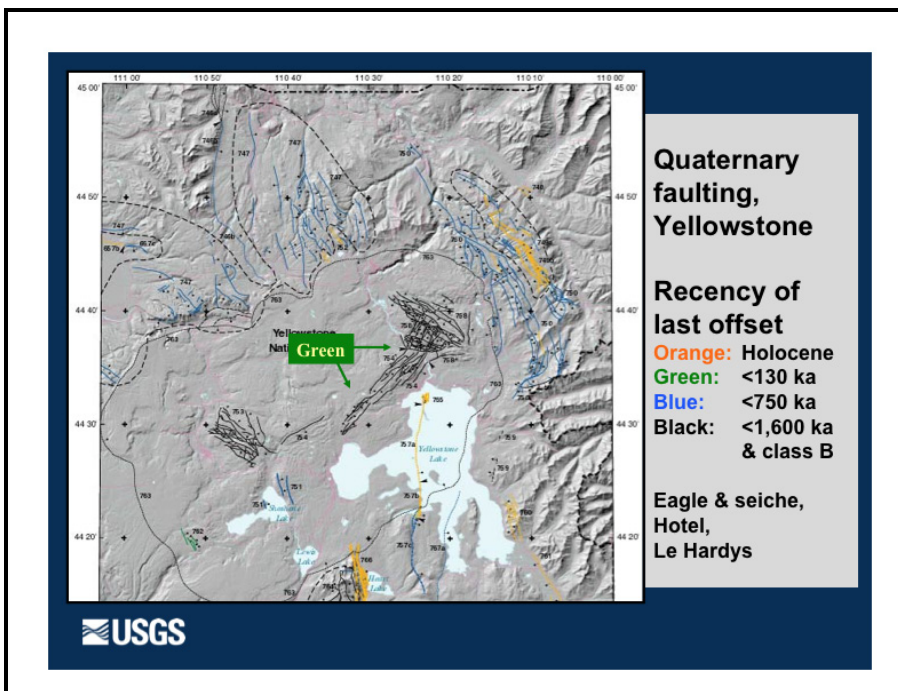

28. 


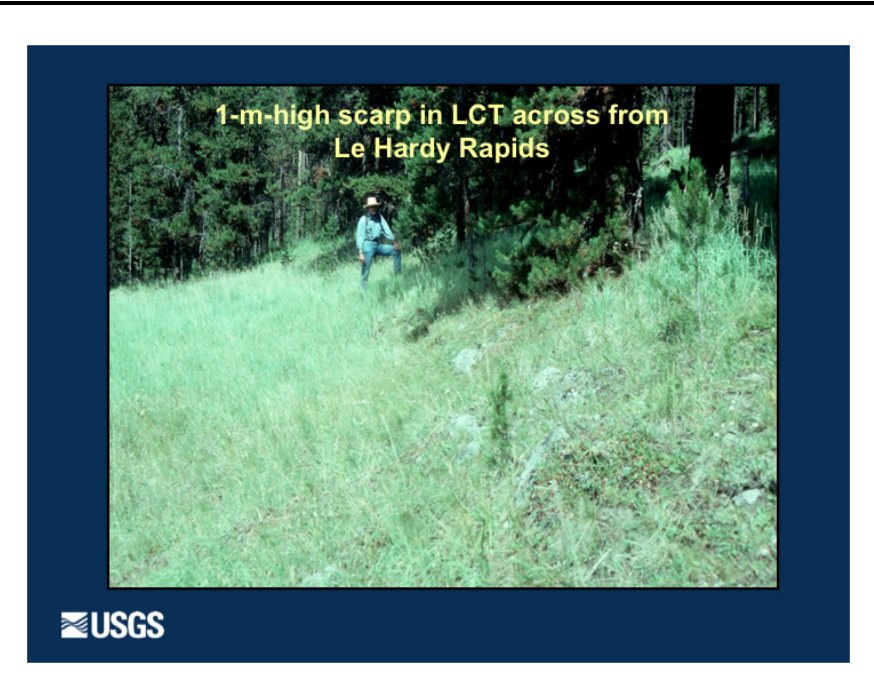

29.

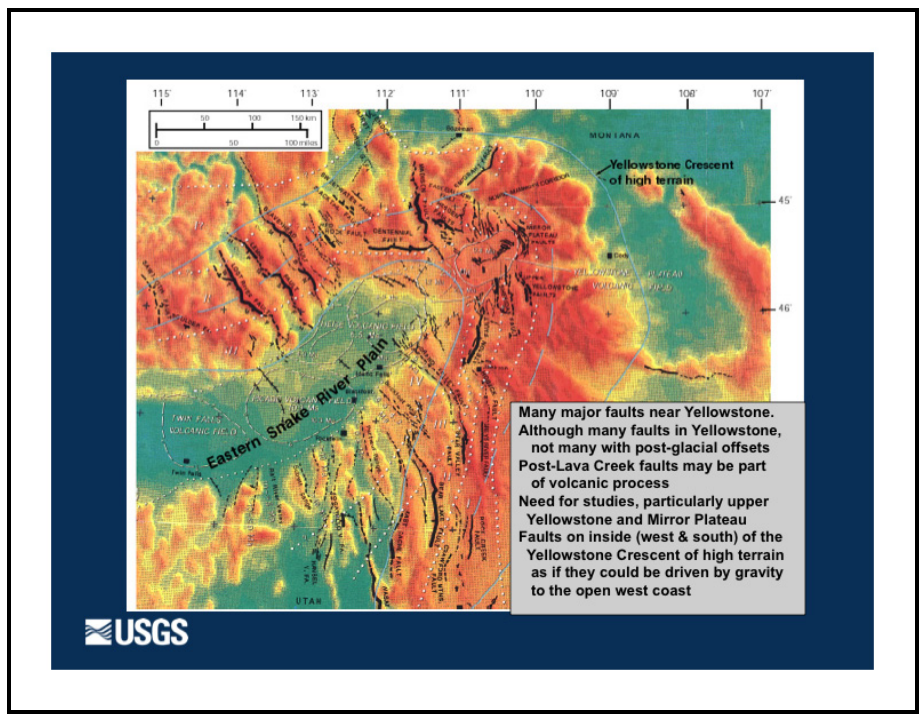

30.
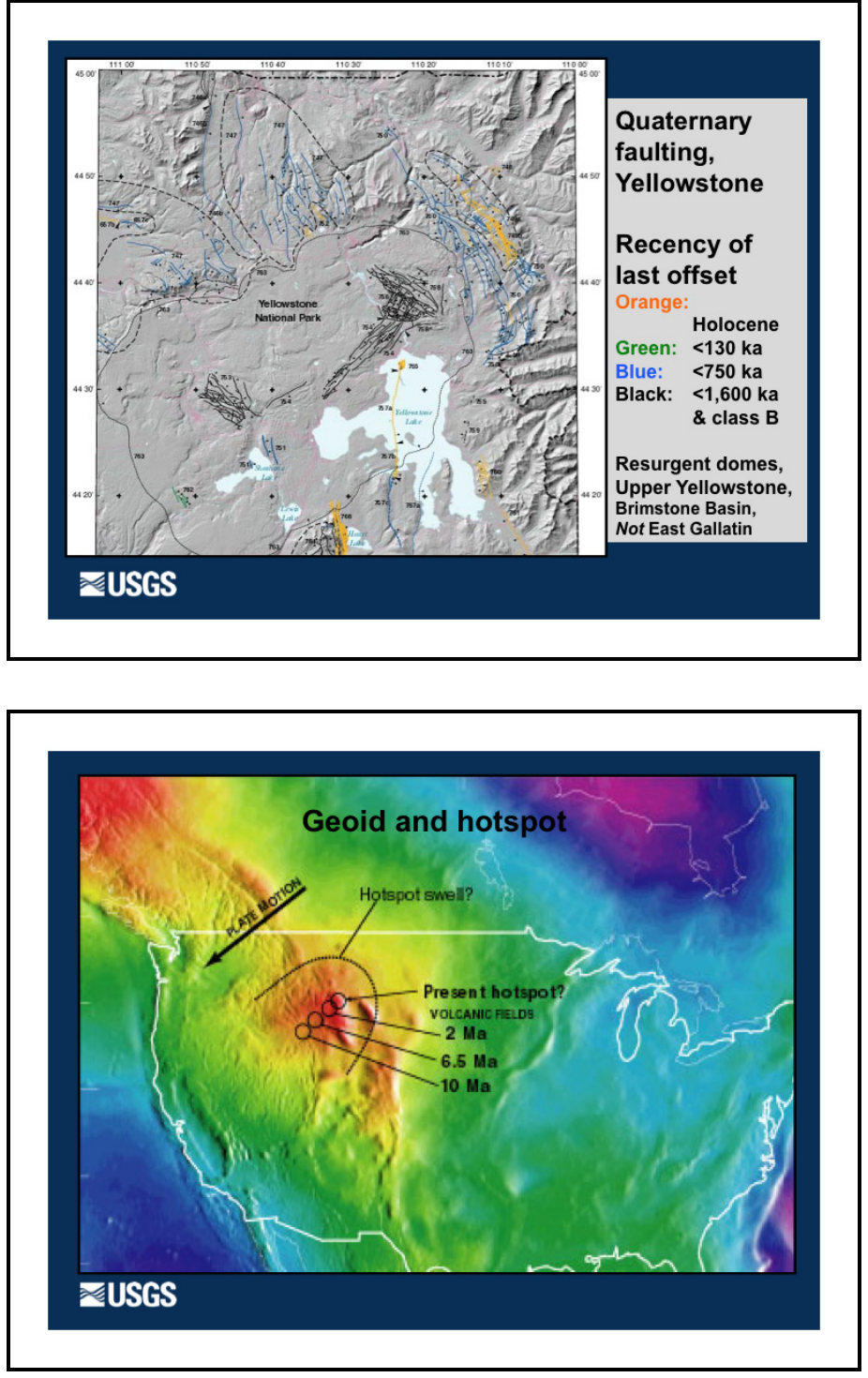
Appendix 3g. Hazardous Quaternary faults in Eastern Oregon, Ian Madin, Oregon Department of Geology and Mineral Industries
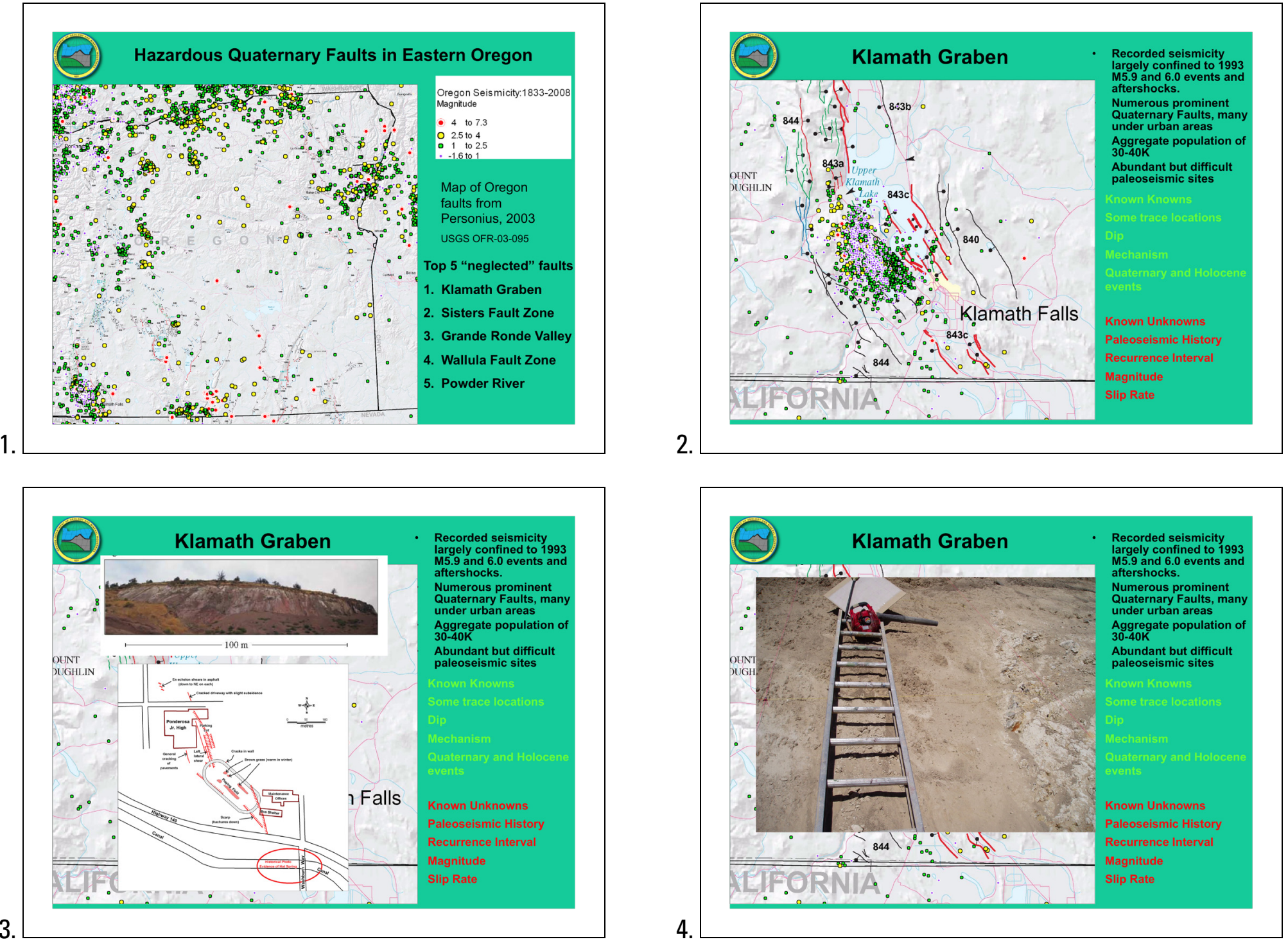

2.

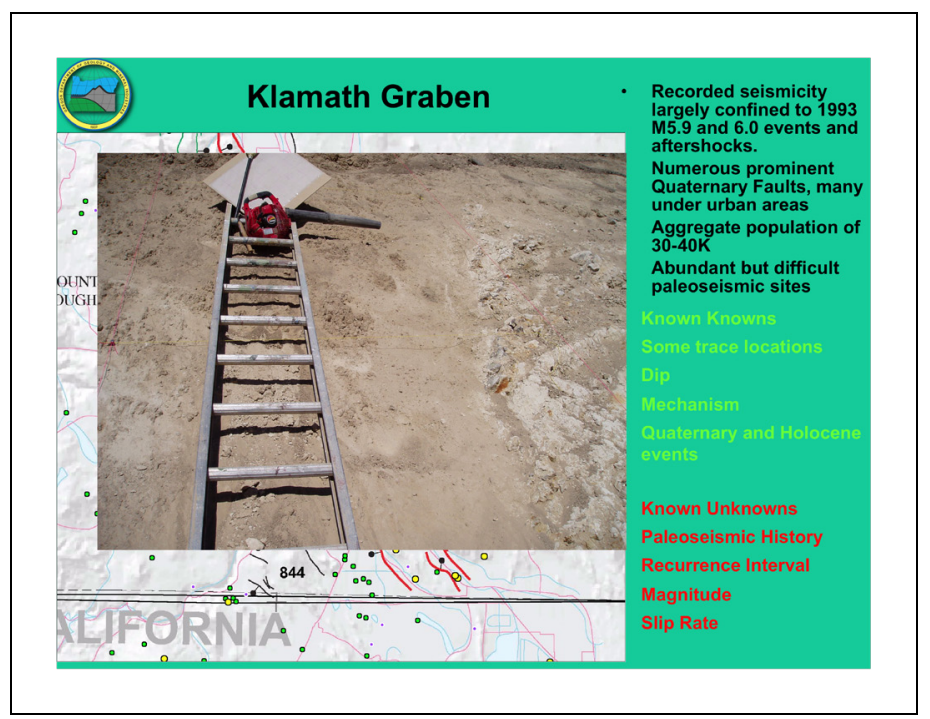



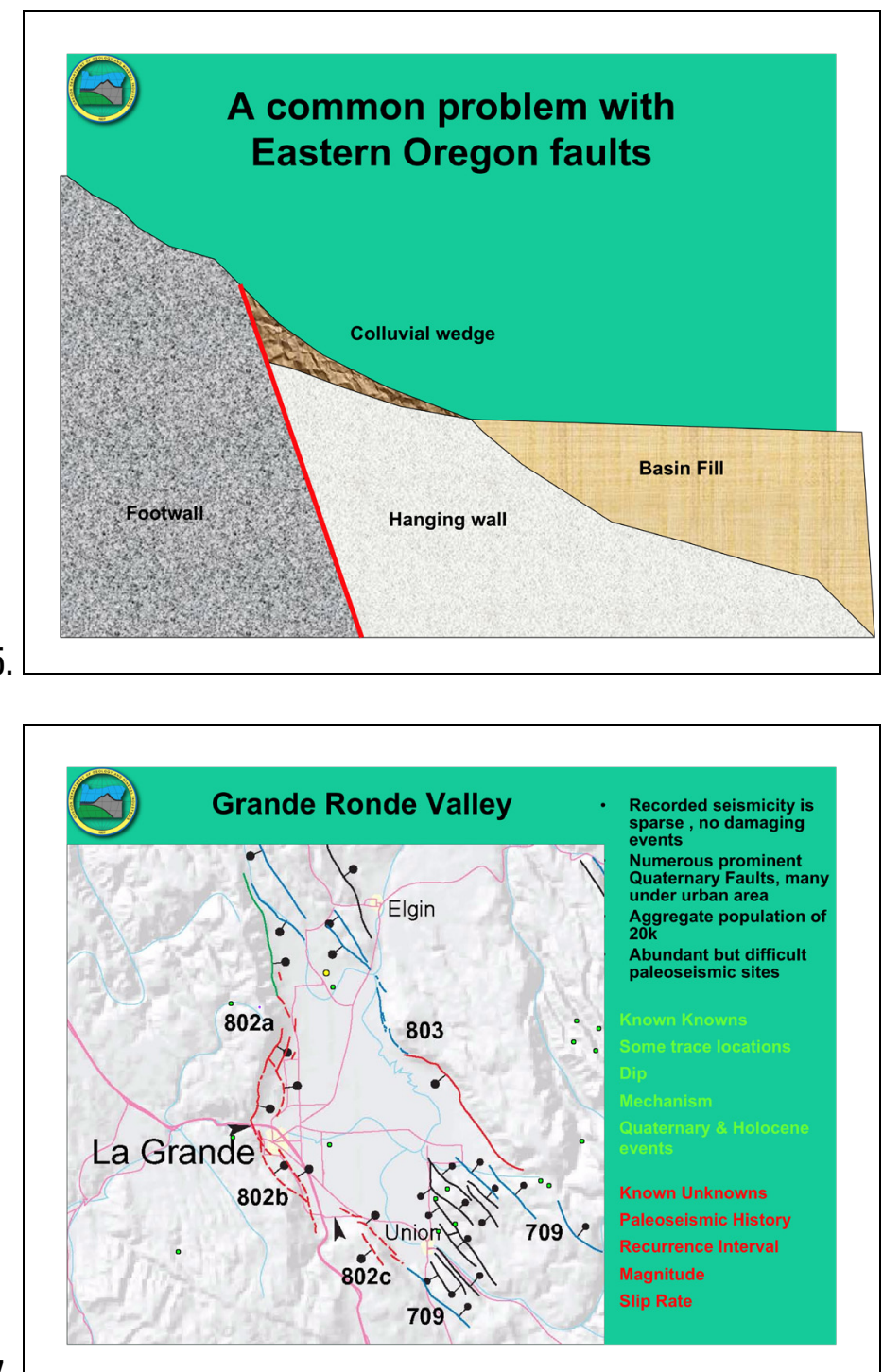

6.
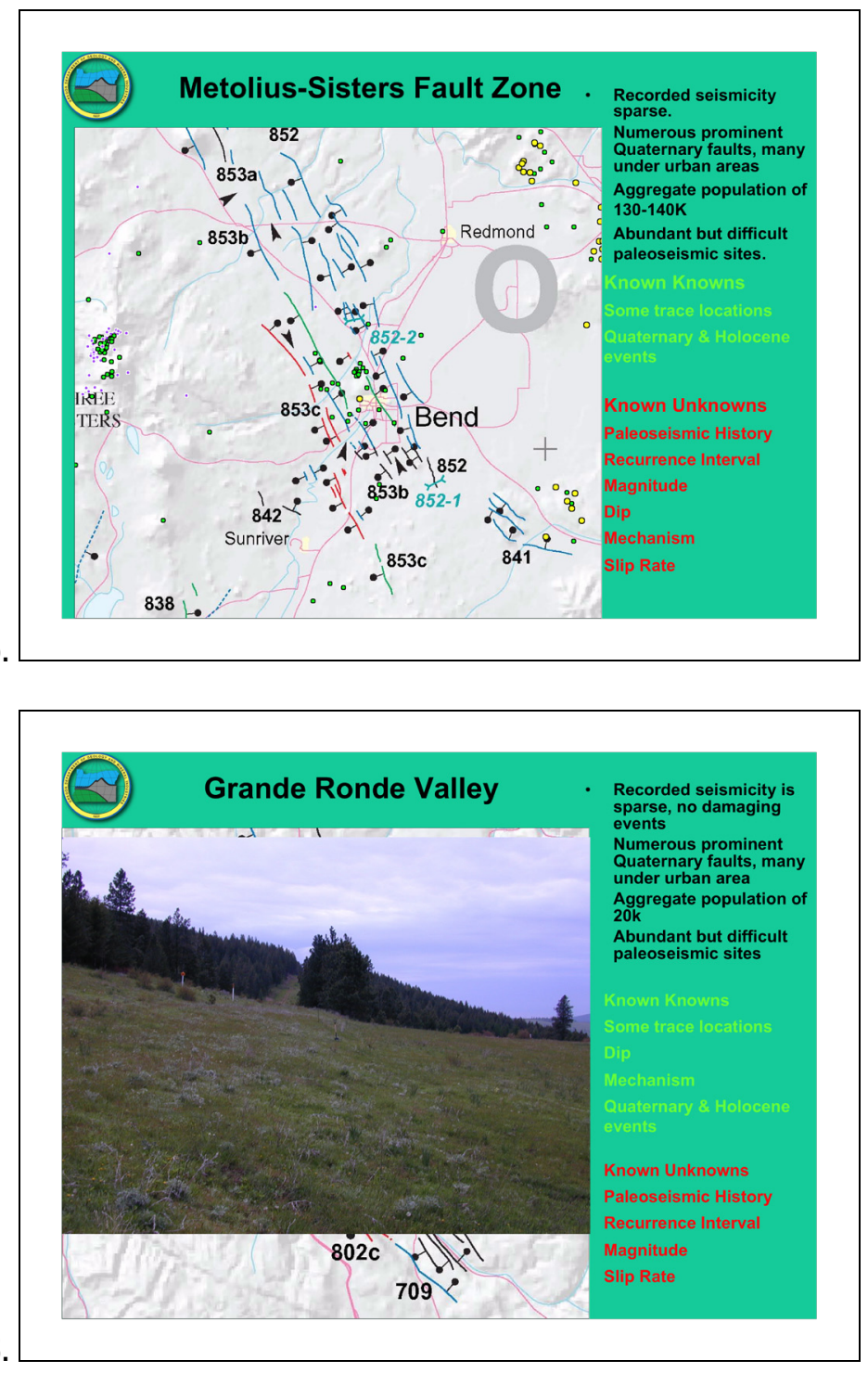


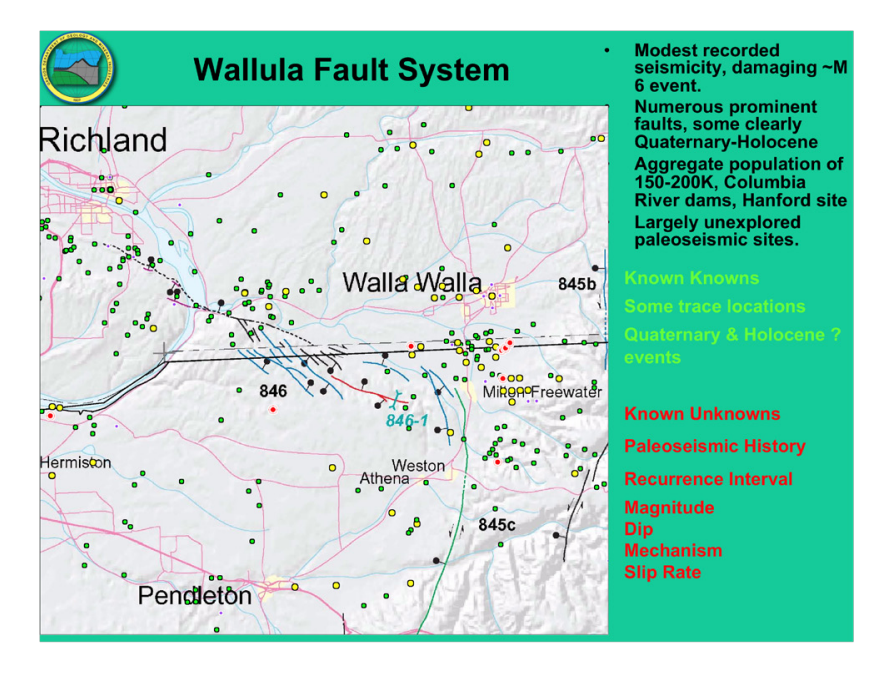

9.

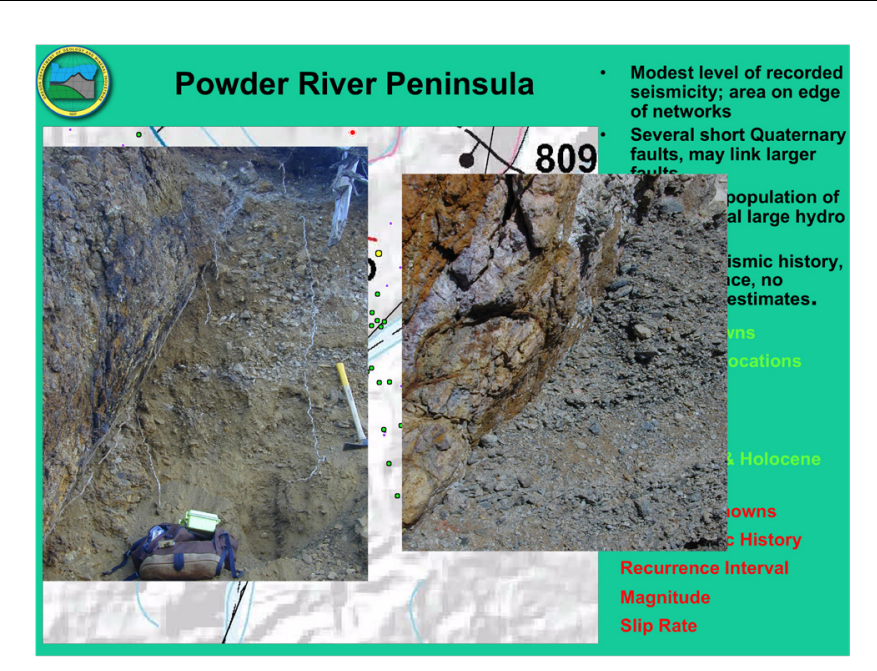

10.
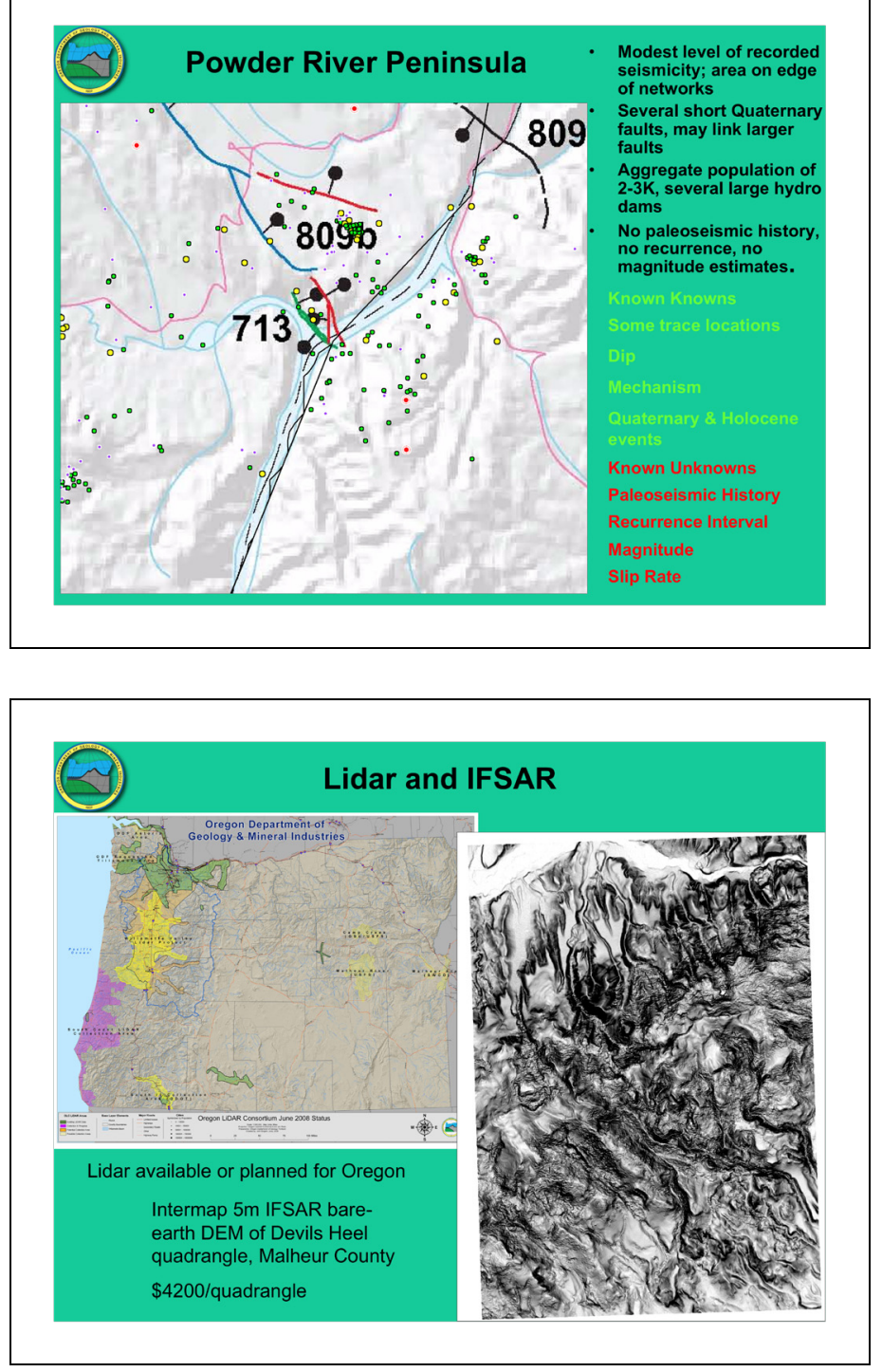

11. 
Appendix 3h. IMW Quaternary faults in the USGS National Seismic Hazard Maps, Kathleen Haller, U.S. Geological Survey
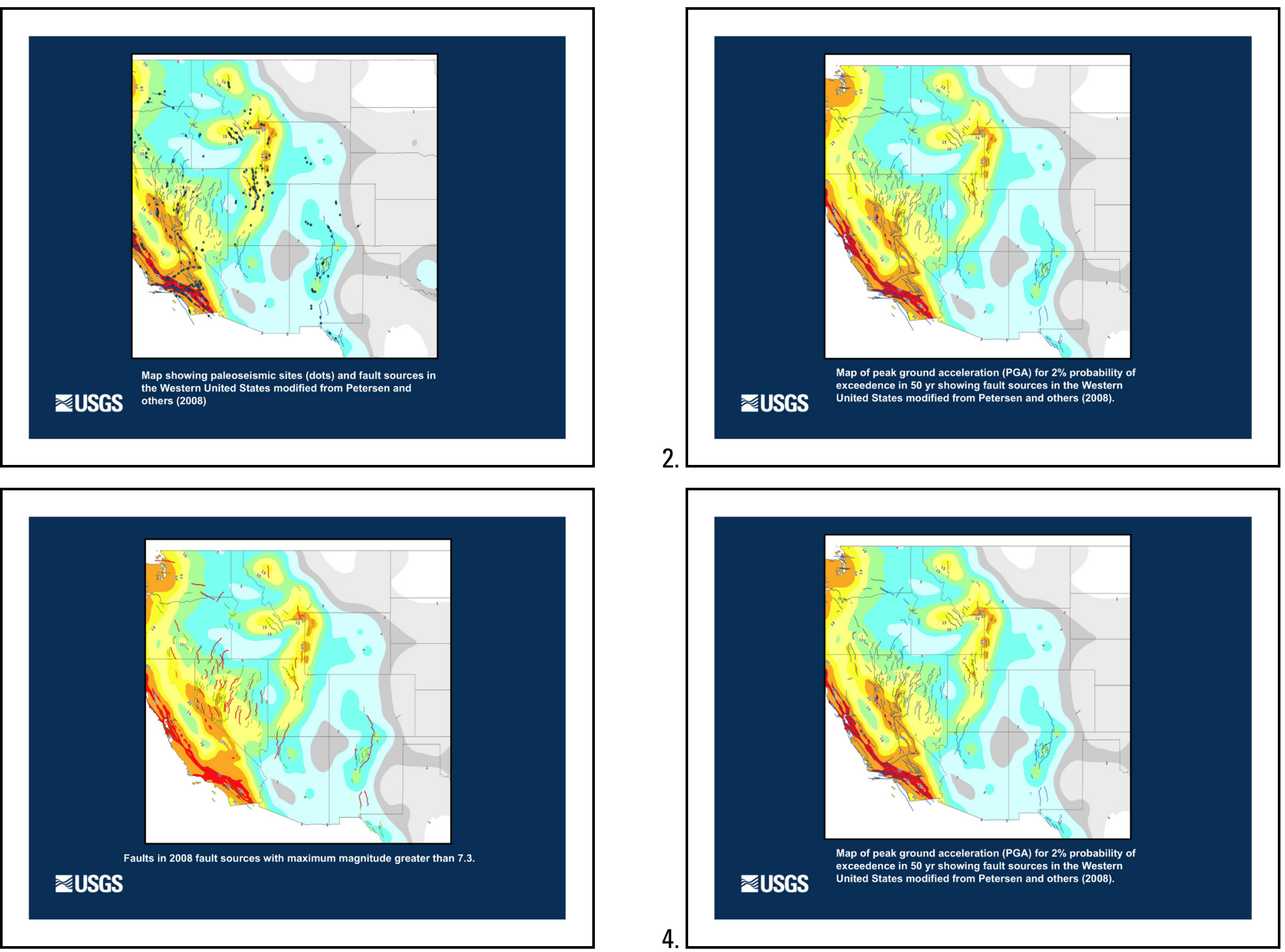